\title{
Belirli Süreli Konut ve Çatılı İşyeri Kiralarında On Yıllık Uzama Süresinin Başlangıç Anı ve Kiraya Verenin Fesih Bildiriminde Bulunabileceği En Erken Zaman Dilimi
}

\author{
Kürşad Yağcı ${ }^{*}$
}

Öz

Konut ve çatılı işyeri kira sözleşmelerinin bildirim yoluyla sona ermesi 6098 sayılı Türk Borçlar Kanununun 347. maddesinde düzenlenmiştir. Söz konusu maddenin birinci fikrasında, belirli süreli konut ve çatılı işyeri kira sözleşmelerinin sona ermesi düzenlenmektedir. Türk Borçlar Kanununun 347.maddesinin birinci fikrası gereğince, konut ve çatılı işyeri kiralarında kiracı, belirli süreli sözleşmelerin süresinin bitiminden en az on beş gün önce bildirimde bulunmadıkça, sözleşme aynı koşullarla bir yıl için uzatılmış sayılır. Kiraya veren, sözleşme süresinin bitimine dayanarak sözleşmeyi sona erdiremez. Ancak, on yıllık uzama süresi sonunda kiraya veren, bu süreyi izleyen her uzama yılının bitiminden en az üç ay önce bildirimde bulunmak koşuluyla, herhangi bir sebep göstermeksizin sözleşmeye son verebilir. Söz konusu on yıllık uzama süresinin ne zaman başlayacağı ve kiraya verenin fesih hakkını en erken ne zaman kullanabileceği konusu, tartışmalıdır. Ayrıca, kira süresinin on yıldan daha uzun olduğu durumlarda, kiraya verenin fesih hakkını ne zaman kullanacağı da değerlendirilmesi gereken ayrı bir konudur. Bu çalışmamızda, belirli süreli konut ve çatılı işyeri kiralarının kiraya veren tarafindan bildirim yoluyla sona erdirilmesi bakımından on yıllık uzama süresinin başlangıç anı ile kiraya verenin sözleşmeyi sona erdirmek için en erken ne zaman bildirimde bulunabileceği konusu, öğretide ileri sürülen görüşler ve yargı uygulaması bağlamında ele alınarak değerlendirilmiştir. Ardından, gerek de lege lata gerekse de lege ferenda olarak konuya ilişkin görüşümüz açıklanmıştır.

\section{Anahtar Kelimeler}

On yılık uzama süresi • Belirli süreli konut ve çatılı işyeri kira sözleşmeleri • Belirli süreli konut ve çatılı işyeri kira sözleşmelerinde on yıllık uzama süresi • TBK m.347• Kira sözleşmesinde on yıllık uzama süresi

\section{Beginning Point of the Ten-Year Extension Period in Fixed Term Lease Contracts for Residential and} Roofed Business Premises and the Earliest Time Period for the Lessor to Notify Termination

\begin{abstract}
The termination of lease contracts of residential and roofed business premises has been regulated under the 347th article of Turkish Code of Obligations numbered 6098. First paragraph of the article regulates the termination of lease contracts for residences (dwelling houses) and roofed business premises (working places) concluded for a limited duration (fixed term contracts). Pursuant to the first paragraph of Article 347, at the fixed term lease contract of residential and roofed business premises, the contract is deemed to be extended for one year under the same conditions unless the tenant gives notice at least fifteen days prior to the expiration of the contract. The lessor cannot terminate the contract based on the expiry of the contract period. However, at the end of the ten-year extension period, the lessor may terminate the contract without any justification grounds, by giving at least three months' notice before the end of each extension period. It is controversial when the ten-year extension period will begin and when the lessor can use the right to terminate at the earliest. In addition, in cases where the lease term is agreed for a period of more than ten years, when the lessor can use the right of termination, is a matter to be evaluated separately. In this study, in terms of the termination of fixed term lease contracts for residential and roofed business premises, the issue of the beginning of the ten-year extension period and the earliest time that the lessor can notify the end of the contract for termination is evaluated in the context of opinions and judicial practice. Finally, our opinion regarding the subject as de lege lata and de lege ferenda is explained.
\end{abstract}

\section{Keywords}

Ten-year extension period • Lease contracts of residential and roofed business premises • Ten-year extension period in fixed-term residential and roofed commercial premises lease agreements $\bullet$ Ten years extension period in lease contracts

\footnotetext{
Sorumlu Yazar: Kürşad Yağcı (Dr. Öğr. Üyesi), İstanbul Üniversitesi, Hukuk Fakültesi, Medeni Hukuk Anabilim Dalı, İstanbul, Türkiye. Eposta: k.yagc@istanbul.edu.tr
}

Atıf: Yağcı, Kürşad, “Belirli Süreli Konut ve Çatılı İşyeri Kiralarında On Yıllık Uzama Süresinin Başlangıç Anı ve Kiraya Verenin Fesih Bildiriminde Bulunabileceği En Erken Zaman Dilimi”, İstanbul Hukuk Mecmuası, 76/2, 2018, 623-665. https://doi.org/10.26650/mecmua.2018.76.2.0022 


\section{Extended Summary}

The termination of lease contracts of residential and roofed business premises has been regulated under the 347th article of Turkish Code of Obligations (TCO) numbered 6098. First paragraph of the article regulates the termination of lease contracts for residences (dwelling houses) and roofed business premises (working places) concluded for a limited duration (fixed term contracts). Pursuant to the first paragraph of Article 347, at the fixed term lease contract of residential and roofed business premises, the contract is deemed to be extended for one year under the same conditions unless the tenant gives notice at least fifteen days prior to the expiration of the contract. The lessor cannot terminate the contract based on the expiry of the contract period. However, at the end of the ten-year extension period, the lessor may terminate the contract without any justification grounds, by giving at least three months' notice before the end of each extension period. It is controversial when the ten-year extension period will begin and when the lessor can use the right to terminate at the earliest.

According to an opinion defended in the doctrine, the lease term agreed in the contract should be included in the ten-year extension period; thus, the ten-year period should begin to operate from the beginning of the lease. This opinion has been criticized on the grounds that according to the wording of the regulation, the ten-year extension period starts from the end of the lease term, not from the beginning of the lease term.

According to a second opinion, the purpose of the legislator to establish a tenyear period is to protect the tenant for a period of twelve years, consisting of the first lease year, ten extension years and a subsequent extension year. Even if the lease term is longer than one year, only the first year of the lease period should be taken into account in accordance with the "tenant's system of protection for twelve years". Thus, the tenant has been protected for only twelve years and the lessor shall be given the opportunity to ensure that the contract does not extend to the thirteenth year. This opinion was criticized for the lack of a legal basis for the calculation of the time period, based solely on the first year of the lease period; however, the law refers to an entire lease period.

According to the prevailing opinion and the Turkish Court of Cassation's practice, the ten-year extension period starts from the expiry of the lease period determined by the contract. Accordingly, the lessor shall have the right to terminate the contract without giving any reason, after each one-year extension period following the completion of the ten-year extension period after the lease period (Lease period + ten-year extension time + at least one-year subsequent extension period). However, this view cannot provide justification grounds as to why the tenant in indefinite-term 
lease agreements is less protected than the tenant in fixed-term lease agreements. Unlike Art.347/I of TCO, which regulates fixed term lease agreements, pursuant to the Art.347/II of TCO, which regulates indefinite term lease agreements, in the case of indeterminate lease terms, the lessor may terminate the contract upon notification of termination pursuant to the general provisions of TCO ten years after the beginning of the lease.

According to the majority of the authors who is in the opinion that the lease period in the contract is included in the ten-year extension period, the tenant may terminate the lease at the end of the ten-year period. As a second opinion, according to the authors defending the tenant's 12-year preservation (1 lease-year +10 -year extension +1 -year subsequent extension), the lessor may terminate the lease at the end of the first year of extension following the completion of the 10-year extension period. The prevailing opinion and the application of the Turkish Court of Cassation are that the lessor may terminate the lease agreement at the end of the first year of extension following the completion of the ten years from the end of the lease term.

In addition, in cases where the lease term is agreed for a period of more than ten years, when the lessor can use the right of termination, is a matter to be evaluated separately. For instance, that a ten-year lease has been concluded. According to the opinions expressed above, at which moment the lessor can terminate the lease? After ten years? At the end of the agreed 15 -year lease period? Or at the end of 26 years (15 years of lease term +10 -year extension period +1 -year subsequent extension period)? According to the above-mentioned views, this issue is also evaluated.

On the other hand, while the lease agreement continues, the parties may sometimes come together and make a new lease agreement or extend the term of the existing lease. When may the lessor in such cases terminate the contract at the earliest time? This question is another issue dealt with in our study.

Finally, one of the questions that should be answered is whether the termination of the lease by the lessor at the end of the ten-year extension period may be prevented by the tenant, as it would be contrary to the principle of good faith. In particular, in the case of lease contracts for roofed business premises (working places), the lessor may want to rent this place to another tenant after the termination of the lease. However, the existing tenant may be willing to pay the rent requested by the lessor from the new tenant in order not to leave this place. Is the lessor still entitled to terminate the lease with the existing tenant?

In this study, in terms of the termination of fixed term lease contracts for residential and roofed business premises, the issue of the beginning of the ten-year extension period and the earliest time that the lessor can notify the end of the contract for 
termination is evaluated in the context of opinions and judicial practice. In our opinion de lege lata, there is a hidden gap in the law for the first paragraph of Article 347 of TCO. Because there is no justification for the artificial separation created by the legislator in terms of ten-year extension period between fixed-term lease agreements (TCO Art.347/I) and indefinite-term lease agreements (TCO Art.347/II). The different applications associated with this distinction lead to unpredictable and/ or unfair results in concrete events. We are of the opinion that, this hidden gap should be filled by applying second paragraph of Article 347 of TCO mutatis mutandis in terms of fixed term lease agreements. In other words, as in the Art.347/II of TCO is stated, the ten-year extension period should be calculated from the beginning of the lease period. Furthermore, in the case of de lege ferenda, amendments to the provision of Art.347 of TCO have been proposed. 


\section{Genel Olarak}

Konut ve çatılı işyeri kira sözleşmeleri' ${ }^{1}$, belirli süreli veya belirsiz süreli olarak kararlaştırılmış olabilir. Belirli süreli konut ve çatılı işyeri kiralarında kiraya veren, sözleşme süresinin bitimine dayanarak sözleşmeyi hemen sona erdiremez. Buna karşı1ık kiracıya kira sözleşmesinin süresinin sona ermesi üzerine kira sözleşmesini sona erdirme imkânı tanınmıştır. Buna göre kiracı, kira sözleşmesinin süresinin bitiminden en az on beş gün önce bildirimde bulunmadıkça, sözleşme aynı koşullarla bir yıl için uzatılmış sayılır. (Türk Borçlar Kanununun, 347.maddesinin 1.fikrasının 1 ve 2.cümleleri, (TBK m.347/I, c.1-2)). Bundan sonraki her uzama yılından on beş gün önce sözleşme kiracı tarafından sona erdirilmedikçe de, bir sonraki uzama yılına geçilecektir. Birer yıllık uzama sürelerinin hangi anda sona ereceği kesin olarak belirli olmamasına rağmen, kanun koyucu, TBK m.347/I'de sözleşmenin türünü "belirli süreli"’ konut ve çatılı işyeri kirası olarak nitelemiştir. Kira bedelindeki artış1 düzenleyen TBK m.344 hükmü saklı kalmak kaydıyla, aksi kararlaştırılmadıkça, uzama sürecindeki yeni kira dönemlerinde de kira sözleşmesindeki hükümler aynen geçerliliğini sürdürecektir.

Mülga Türk Kanunu Medenisi (eBK) ve mülga 6570 sayılı Gayrimenkul Kiraları Hakkında Kanun (GKHK) gereğince, kiraya veren, belirli süreli konut ve çatılı işyeri kirası sözleşmesini, sözleşme süresi sona erdiği için sona erdirememekteydi ve ancak olağanüstü fesih koşulları varsa (örneğin TBK m.316; eBK m.256) veya kanunda sayılan sınırlı tahliye nedenleriyle (TBK m.350-352; mülga GKHK m.7) sözleşmenin sona erdirilebilmesi mümkün olabilmekteydi. Mülga mevzuat dönemindeki bu düzenlemenin, kanımızca, anayasal bir hak olan "mülkiyet hakkının sınırlanmasında

\footnotetext{
Bu çalışmamızda, "belirli süreli konut ve çatılı işyeri kiraları" ifadesini kullanırken, niteliği gereği geçici kullanıma özgülenmiş konut ve çatılı işyerlerinin altı ay ve daha kısa süreyle kiralanmalarını bu ifadenin kapsamı dışında tutuyoruz. Konut ve çatılı işyeri kiralarına ilişkin hükümler, konut veya çatılı işyeri için yapılan kira sözleşmesinin süresinin en az altı ay ya da daha uzun olması ve kiralananın geçici kullanıma özgülenmemiş olması halinde, uygulama alanı bulabilir. Zira TBK m.339/I, c.2 gereğince, konut ve çatılı işyeri kiralarına ilişkin hükümler, "niteliği gereği geçici kullanıma özgülenmiş taşınmazların altı ay ve daha kısa süreyle kiralanmalarında uygulanmaz". Bu hallerde, kira sözleşmesinin genel hükümleri uygulama alanı bulur.

2 Kiracının bildirim yoluyla kira sözleşmesini sona erdirmesinin, teknik anlamda "fesih bildirimi" niteliğinde olmadığı, zira söz konusu bildirimin sözleşme süresinin sona ermesi koşuluna bağlandığı; buna karşılık TBK m.347/II ve III hükümlerinde geçen bildirimin fesih bildirimi niteliğinde olduğu yönünde: Ercan Akyiğit, 6098 sayılı Türk Borçlar Kanunu'nda Kira Sözleşmesi, Seçkin, Ankara 2012, s.162, ayrıca bkz. s. 164, 166-167.

TBK m.347/I'de geçen "belirli süreli sözleşme" ifadesine rağmen, kira sözleşmesinin sona ermesinin kiracının on beş gün önceden bildireceği bozucu koşul niteliğindeki bildirime bağlı olduğu ve yine sözleşmenin sürenin sona ermesi üzerine değil, ancak fesih bildirimi üzerine sona erebileceği gerekçeleriyle, TBK m.347/I'de aslında belirsiz süreli sözleşmelerin düzenlediği görüşünde: Seçkin Topuz/ Ferhat Canbolat, "Taşınmazlara İlişkin Kira Sözleşmelerinin İçeriğinin Örtülü İrade Beyanıyla Değiştirilmesi” Hacettepe Hukuk Fakültesi Dergisi, C.I, S.1, Ankara 2011, s.23 vd. Karşı görüşteki Demircioğlu'ya göre, "bir sözleşmenin süresine ilişkin belirli veya belirsiz nitelemesi, tarafların sözleşmeyi kurarken ortaya koydukları iradeleri dikkate alınarak yapılmalıdır. Buna göre taraflar belli bir sürenin geçmesiyle başkaca bir işleme gerek olmaksızın sözleşmenin sona ermesini öngörmüşler ise, bu sözleşme belirli sürelidir. Kanun'un düzenlemesi sebebiyle tarafların arzu ettikleri neticenin ortaya çıkıp çımaması, ayrı bir mesele olup; bu, söz konusu sözleşmelerin tabi tutuldukları kanuni rejim ile ilgilidir”. Bkz. Huriye Reyhan Demircioğlu, "6098 Sayı1ı TBK'ya Göre Konut ve Çatılı İşyeri Kiralarında Kiraya Verenin Bildirimli Fesih Hakkını Kullanabilmesinde Süre Sorunu”, Banka ve Ticaret Hukuku Dergisi, C.31, S.2, 2015, s.177, dn.23. Acar ise, kira süresi kararlaştırılmak suretiyle akdedilen konut ve çatılı işyeri kira sözleşmelerini, "gerçek olmayan belirli süreli kira sözleşmesi" olarak nitelendirmektedir: Bkz. Faruk Acar, Kira Hukuku Şerhi (TBK m. 299-326), 4. Bask1, Beta, İstanbul 2017, TBK m.300, N.36, s.83.

3 Bilineceği üzere, kira sözleşmesinde kiraya verenin aynı zamanda kiralananın maliki olması şart değildir. Ancak olayların
} 
ölçülülük ilkesi” ile açıklanması güçtü ${ }^{4}$. Zira kira sözleşmesinde, her iki taraf için de geçerli olan bağlayıcı zaman dilimi, bir kira süresi kararlaştırılmak suretiyle belirlendikten ve bu surette taraf iradeleri ortaya konulduktan sonra, kiraya vereni kanun gereğince ne zaman sona ereceği belli olmayan veya kiracının -süresinde fesih bildiriminde bulunmak kaydıyla- ne zaman isterse o zaman sona erdirebileceği bir hukuki ilişkiye zorlamak, kanımızca, sözleşme dengesinin kanun eliyle bozulması ve mülkiyet hakkının aşırı ölçüde sınırlanması anlamına geliyordu ${ }^{5}$.

01.07.2012 tarihinde yürürlüğe giren 6098 sayılı Türk Borçlar Kanununun hazırlığı aşamasında komisyon tarafından önce uzama süresi on beş yıl olarak belirlenmişken; TBMM Adalet Komisyonu, bu süreyi "mülkiyet hakkının ölçüsüz şekilde sınırlandırılamayacağı temelinde makul bir seviyeye indirilmesi amacıyla" on y1la düşürmüştür6́.

Nihayet, yeni ihdas edilen TBK m.347/I, c.3 hükmü ile, kiraya verene mülga 6570 sayılı Kanunda ve mülga Türk Kanunu Medenisinde bulunmayan bir sona erdirme imkânı tanımıştır. Böylece kiraya verenin sözleşme süresi sona erdiği için kira sözleşmesini bildirim yoluyla sona erdiremeyeceği kuralı sınırlanmıştır. Diğer bir deyişle, kiraya verenin bildirim yoluyla kira sözleşmesini sona erdirme yetkisine sahip olamaması sebebiyle mülkiyet hakkının sınırlanmasına, zaman yönünden bir sınırlama getirilmiştir. TBK m.347/I, c.3 gereğince, “on yıllık uzama süresi sonunda kiraya veren, bu süreyi izleyen her uzama yılının bitiminden en az üç ay önce bildirimde bulunmak koşuluyla, herhangi bir sebep göstermeksizin sözleşmeye son verebilir". Böylece kanun koyucu, on y1llı uzama süresinin sonunda, kiraya verene, bozucu yenilik doğuran bir hak tanımıştır . Üç aylık süre, asgari süreyi ifade etmektedir;

çoğunda kiraya veren aynı zamanda malik olduğu için, kanun koyucu haklı olarak, TBK m.347 düzenlemesinde bu somut durumu temel almak suretiyle düzenleme yapma yoluna gitmiştir.

4 Murat Doğan/Cem Baygın, “Türk Borçlar Kanunu Tasarısı'nda Kira Sözleşmesine İlişkin Hükümler”, Hukuki Perspektifler Dergisi, S.4, Ağustos 2005, s. 129; Murat Doğan, Konut ve Çatılı İşyeri Kira Sözleşmelerinin Sona Ermesi, Adalet, Ankara, 2011, Sona Erme, s.61-62; M. Murat İnceoğlu, Kira Hukuku, C.2, 1.Bası, XII Levha, İstanbul, 2014, s.329. Hatta mülga kanun döneminde, kiracının ölümü dahi tek başına kira sözleşmesinin sona ermesi için yeterli değildi. Bkz. TBK m.356. Farklı görüşte bkz ve karş. Mustafa Alper Gümüş, "Kiracı ve Kiraya Veren Arasında Bir Gerilim Kaynağı Olarak Belirli Süreli Konut ve Çatılı İşyeri Kiralarında Kiraya Verenin Sahip Olduğu Kira Sözleşmesini Bildirim Yoluyla Sona Erdirme Hakkı (TBK m.347/I, c.3)”, Prof. Dr. Özer Seliçi'nin Anısına Armağan, Bahçeşehir Üniversitesi Hukuk Fakültesi Dergisi Özel Sayısı, C.11, S.145-146, Eylül-Ekim 2016, s.121. Ayrıca bkz. Demircioğlu, s.178-179.

5 Kiraya verene süreye dayalı olarak fesih hakkı tanınmamasının, irade özerkliğine ve bunun görünüm biçimi olan sözleşme serbestisine aykırı düşeceği, öte yandan bunun, mülkiyet hakkının herkese karşı ileri sürülebilme ve eşya üzerinde doğrudan hakimiyet sağlama özellikleriyle de bağdaşmadığı yönünde bkz. ve karş. Demircioğlu, s.180.

${ }_{6}$ TBMM Genel Gerekçe, Dönem:23, Yasama Yı1ı: 3, Sıra Sayısı: 321, s.282 (https://www.tbmm.gov.tr/sirasayi/ donem23/ yil01/ss321.pdf).

7 Fikret Eren, Borçlar Hukuku Özel Hükümler, 4. Bas1, Yetkin, Ankara 2017, s.411; Doğan, Sona Erme, s.66; Mustafa Kırmızı, Açıklamalı- İçtihatlı Kira Hukuku, 1.Baskı, Bilge, Ankara, 2013, s.412. On yıllık uzama süresinin sonunda kiraya veren tarafından yapılacak bu bildirimin, teknik anlamda "kira sözleşmesinin sona ereceği (uzatılmayacağı)" bildirimi olarak mı, yoksa "fesih bildirim" olarak mı nitelenmesi gerekeceği konusunda, Akyiğit, kiracının kira süresi sonundaki bildirimi bakımından savunduğu görüşe paralel olarak (bkz. yukarıda dn.2), kiraya verenin buradaki bildiriminin, kira sözleşmesinin sona ereceği (uzatılmayacağı)" bildirimi niteliğinde olduğunu savunur (s.168).

Fesih bildiriminin tek başına işlev görmediği, ancak sürenin dolması ile tamamlayıcı bir rol oynadığı gerekçesiyle; bu bildirimin "yenilik doğuran hak benzeri”" bir irade açıklaması olduğu görüşünde: Cevdet Yavuz/Faruk Acar/Burak Özen, Cevdet Yavuz Türk Borçlar Hukuku Özel Hükümler, (Hazırlayanlar: Cevdet Yavuz/ Faruk Acar/ Burak Özen), 10. Bası, Beta, İstanbul 2014, s.657; aynı gerekçeyle bu bildirimin, "değiştirici yenilik doğuran hak benzeri” bir irade açıklaması 
örneğin kiraya veren dört ay kala da fesih bildiriminde bulunabilir. Bildirime rağmen kiracının kiralananın zilyetliğini iade etmemesi halinde, kiraya veren kiralananın iadesini dava yoluyla talep edebilecektir ${ }^{8}$. Ekleyelim ki, on yıllık uzama süresinin dolmuş olması, kiraya verene tanınan fesih bildirim hakkının doğması için bir ön şarttır ve bu durum hâkim tarafindan re'sen nazara alınır9 .

Belirsiz süreli konut ve çatılı işyeri kira sözleşmelerinde ise, kira sözleşmesinin süresi bulunmadığ gibi, "uzama süresi”nden de söz edilemez. Bu sebeple kanun koyucu belirsiz süreli kira sözleşmelerinde kiraya verenin olağan fesihle sözleşmeyi sona erdirememe yetkisini, kira sözleşmesinin başlangıcından itibaren işlemeye başlayacak bir süre ile sınırlandırmıştır. TBK m.347/II gereğince, "belirsiz süreli kira sözleşmelerinde, kiracı her zaman, kiraya veren ise kiranın başlangıcından on yll geçtikten sonra, genel hükümlere göre fesih bildirimiyle sözleşmeyi sona erdirebilirler".

Elbette gerek belirli süreli gerekse belirsiz süreli konut ve çatılı işyeri kira sözleşmelerinin kiracının temerrüdü sebebiyle (TBK m.315) ya da olağanüstü fesih halleri sebebiyle süresinden önce sona erdirilmesi (TBK m.316; 331), koşulları mevcut ise her zaman mümkündür. Nitekim TBK m.347/III gereğince, "genel hükümlere göre fesih hakkının kullanılabileceği durumlarda, kiraya veren veya kiracı sözleşmeyi sona erdirebilir". Yine konut ve çatılı işyeri kirası sözleşmesinin dava yoluyla sona erdirilmesi (tahliyesi) sebepleri (kiraya verenin ya da yeni malikin gereksinimi, yeniden inşa ve imar, tahliye taahhüdü, iki haklı ihtarla tahliye sebepleri) (TBK m.350-352) mevcut ise, kiralananın tahliyesi bu özel hükümlere tabi olacaktır ki, bu hükümler TBK m.347/I ve II'de öngörülen olağan fesih yönteminden ayr1 ve sebebe dayanan birer sona erdirme yöntemleridir. Oysa TBK m.347/I, c.3 ve 347/II'de düzenlenen fesih hakk1 bakımından, bir sebep gösterilmesine gerek bulunmamaktadır. Ekleyelim ki, TBK m.347 hükmü ile tanınan sebep göstermek zorunluluğu olmaksızın kira sözleşmesini feshedebilme hakkı, kiraya veren açısından bir tazminat yükümlülüğ̈̈ de doğurmaz ${ }^{10}$.

Kiraya verenin söz konusu fesih hakkını kullanabilmesi için, on yıllık uzama süresinin dolmuş olmasının bir ön şart olarak düzenlenmesiyle, bir yandan kiraya verenin mülkiyet hakkının aşırı ölçüde sınırlanması engellenerek toplumda oluşan

niteliğinde olduğu görüşünde: Mustafa Alper Gümüş, "Yeni” 6098 Sayılı Türk Borçlar Kanunu'na Göre Kira Sözleşmesi (TBK m.299-356), Vedat Kitapçıllk, 2. Bası, İstanbul 2012, s.312.

8 Söz konusu dava, TBK m.344 anlamında kiralananın geri verilmesi davası olup, tahliye davası niteliğinde değildir. Detaylı bilgi için bkz. Haluk Burcuoğlu, Uygulama ve Öğretiden Örneklerle Özel Hukukta (Aile-Kira-Borçlar Hukukunun Diğer Bazı Bölümleri) I. Quo Vadis (Nereye) II. Nihayet (TBK.'nun her nedense unutulan hükümleri uygulanmaya başlandı), 1. Bası, Vedat Kitapçılık, İstanbul 2016, s.36-38; Ahu Ayanoğlu Moralı, "Konut ve Çatılı İşyeri Kiralarında Sözleşmenin Sona Ermesi m.347-349”, İstanbul Şerhi Türk Borçlar Kanunu, Yürürlük Kanunu, C.II, Özel Borç İlişkileri, Ed. Rona Serozan, Turgut Öz, Faruk Acar, Emre Gökyayla, H. Murat Develioğlu, 2.Baskı, Vedat, İstanbul, 2018, N.58.

9 Gümüş, Armağan, s.129.

10 Yavuz/Acar/Özen, s.661; Doğan, Sona Erme, s.66-67; İnceoğlu, II s.330; Engin Daşlı, 6098 Sayılı Türk Borçlar Kanunu Hükümlerine Göre Kira Sözleşmesinin Feshi, 1. Bası, Aristo Yayıncılık, Erzincan 2017, s.162. Karş. TBK m.331. 


\title{
huzursuzluk bir nebze engellenmiş, diğer yandan da kiracının kira süresi sonunda derhal tahliye edilme endişesi yaşamasının önüne geçilmiş; böylece kiraya veren ile kiracının menfaatlerinin dengelenmesi sağlanmaya çalışılmıştır ${ }^{11}$.
}

\author{
Son olarak ekleyelim ki, on y1llık uzama süresine ilişkin TBK 347/I, c.3 ve f.II \\ hükümleri ile 6101 sayılı Türk Borçlar Kanununun Yürürlüğü ve Uygulama Şekli \\ Hakkında Kanun (Yürürlük K) m.1/I, c.2 ve Geçici m.2 hükümleri' ${ }^{12}$ hakkında, söz
}

11 Doğan, Sona Erme, s.63-64; Demircioğlu, s.179. TBKm.347 hükmünün gerekçesine göre: “Böylece, kira sözleşmesi sebebiyle, kiraya verenin, aradan uzun yıllar geçse bile, kiralananın dolaysız zilyedi olamamasının toplumda yarattı̆̆ huzursuzluk dikkate alınmış ve kiraya verene, fikrada belirtilen koşullar gerçekleşince, tazminat ödemekle yükümlï olmaksızın, sözleşmeyi tek tarafl olarak sona erdirebilme hakkı tanınmıştır". TBMM Genel Gerekçe, Dönem:23, Yasama Y11: 3, Sira Sayısı: 321, s.154 (https://www.tbmm.gov.tr/sirasayi/ donem23/yil01/ss321.pdf).

Demircioğlu, TBK m.347 hükmü ile kiraya verene tanınan fesih imkânını olumlu karşılamaktadır. Yazar, yapılan düzenlemeyle mülkiyet hakkının korunmasının hedeflendiğini, düzenlemenin temelinde kiraya veren ile kiracının çatıșan menfaatleri arasında bir denge kurma amacının yattığını belirterek, gerekçede yer alan, "kiralananın dolaysız zilyedi olamamasının toplumda yarattı̆̆ huzursuzluk" ifadesini, kanunun amacını yeterince iyi yansıtmadığ 1 için, eleştirmektedir (s.179).

TBK m.347 hükmünün gerekçesini eleștiren Gümüș ise, kanun değișikliğini isabetli bulmamaktadır. Yazara göre, “ kiraya verenin kiralanan konut ve çatılı iş yerine dolaysız zilyet olmasını gerekli kılacak haklı sebepleri Kanun koyucu zaten "tahliye davası sebebi" olarak düzenlediğinden bu gerekçe biraz "eğreti" durmaktadır. Aslında kiraya verenlerin huzursuzluğunun temelinde "kira bedeline dayalı çlkarlarına yönelik sınırlama" yatmaktadır". Yazara göre, her ne kadar kira tespit davası ile kira bedellerinin güncellenmesi imkânı söz konusu olsa da, bu belirleme hakkaniyet ilkesine göre yapıldığından, tespit edilen yeni kira bedeli her zaman rayiç kira bedelinin altında kalmaktadır. Öte yandan kira tespit davası açmak, kiraya veren için kișisel ve mali açılardan külfetlidir. Bu sebeple kiraya veren, daha kolay bir yol olarak kiracıyı kiralanandan çıkarma yöntemini tercih etmek istemektedir. "Bu noktada konut veya çatılı işyeri kiralarına ilişkin TBK hükümlerinin, kiraya verenin parasal çıkarlarını arka plana atarak, kiracıyı kamusal esenlik adına korumaya yönelik emredici niteliği göz önüne alındığında, TBK m.347/I, c.3 ve m.347/II, söz konusu yaklaşımdan açık ve şaşırtıcı bir sapma oluşturmaktadır" (Armağan, s.121). Hatta yazara göre, TBK m.347/I, c.3 hükmünün Anayasa’ya aykırılığı dahi tartıșılır durumdadır (Armağan, s.138). Aynı yönde bkz. Kerem Cem Sanlı, "Kiraya Verenin On Yıllık Uzama Süresi Sonunda Bildirim ile Kira Sözleşmesini Sona Erdirmesi: Hukuk ve Ekonomi Perspektifinden Bir İnceleme”, Legal Hukuk Dergisi, S.151, 2015, s.141. Yazara göre, "(TBK m.347 hükmünün gerekçesi) problemlidir. Kiraya verenin dolaysız zilyet olmast, kiralananı bizzat kullanması anlamına gelir. Ĕger dolaysız zilyet olamamaktan ötürü huzursuz oluyorsa, gereksinim nedeniyle tahliye hakkını (TBK. m. 350/I) kullanarak bu huzursuzluğu giderebilir. Kanun ona bu imkânı vermiştir. Ayrıca bu durumda herhalde fesih sonrasında kiraya verenin kiralananı bizzat kullanması yükümlülüğü getirmek ve başkasına kiraya vermesini önleyen bir kural koymak gerekirdi. Bu konuda bir düzenleme yoktur. (Yazar) bu nedenle gerekçenin doğru ifade edilmediğini düşün(mektedir). (Yazara göre) hükmün öngörülmesinin asıl sebebi, kiraya verenin dolaysız zilyet olamamast değil, uzayan kira dönemlerinde kiralananın, kiralık dĕ̆erini elde edememesidir. Diğer bir ifadeyle uzama dönemlerindeki yasal kira artışı, muhtemelen, piyasa rayicinin altında kalmaktadır. Bu, kiraya veren için bir maliyet oluşturmaktadır. Uzama süresi arttıkça da bu maliyet artmakta ve kiraya veren açısından bakıldığında, kira sözleşmesinin sonlandırılması önem kazanmaktadır" (s.141).

Kanaatimizce, nispi hak niteliği olan kira sözleşmesinin, "tahliye sebepleri” dışında sona erdirilememesi gerektiğini kabul etmek, mülkiyet hakkının aşırı ölçüde sınırlanması anlamına gelir. Bir sınırlı ayni hak olan intifa hakkı dahi belirli bir sürenin sona ermesi ile veya intifa hakkı sahibinin ölümü ile sona ererken, kira sözleșmesinin tahliye sebepleri ya da olağanüstü fesih koşulları olmadıkça sona erdirilememesi, bu sözleşmeyi, nispi niteliğinden çıkarıp, olsa olsa "sınırlı ayni hak ötesi” bir kurum haline getirmek anlamına gelir. Öte yandan kiracının her durumda korunması düşüncesi de isabetli değildir. Önemli olan ekonomik olarak güç durumda olan tarafın korunmasıdır. Bu taraf, her zaman için kiracı olmayabilir. Nihayet, kira bedelinin, TBK m.344 gereğince hakkaniyet düșüncesi ile rayicin altında belirlenmekte olmasının ne denli isabetli bir düzenleme olduğu da ayrıca tartışılmak gerekir. Şu kadarını belirtelim ki, kiracıların rayiç kira bedeli altında kira bedeli ödemelerini sağlamak, kiraya verenin kiralanandan elde etmesi gereken menfaatten daha az bir menfaate razı olmak zorunda bırakılmasıdır ki, kiracıların ekonomik güçlüklerini giderme yükümlülüğü, kiraya verene değil; Devlet'e aittir.

126101 sayılı Türk Borçlar Kanununun Yürürlüğü ve Uygulama Şekli Hakkında Kanunun (Yürürlük K) Geçici 2.maddesi olmasaydı, bu Kanunun 1.maddesinin, son cümlesi uyarınca 6098 sayılı Türk Borçlar Kanununun yürürlüğe girmesinden önce akdedilmiş olan belirli süreli konut ve çatılı işyeri kira sözleşmelerinin sona ermesine Türk Borçlar Kanunu hükümlerinin (dolayısıyla da TBK m.347 hükmünün) uygulanması gerekecekti. Ancak Yürürlük Kanunun Geçici 2.maddesi ile, Türk Borçlar Kanununun yürürlüğe girdiği 01.07.2012 tarihinden önce akdedilen belirli süreli konut ve çatılı işyeri kira sözleşmelerinin sona ermesi bakımından özel bir düzenleme getirilerek, bu sözleşmeler bakımından TBK 347'deki on yıllık uzama süresi sonunda tanınan fesih imkanının, on yılın sonunda hemen uygulanması, belirli koşullarla engellenmiştir. Şöyle ki, Yürürlük K. Geçici m.2 gereğince, "Bu Kanunun 1 inci maddesinin son cümlesi hükmü bir defaya mahsus olmak üzere, bu Kanunun yürürlüğe girmesinden önce Türk Borçlar Kanununun 347 nci maddesinin birinci fikrasının son cümlesinde öngörülen kira sözleşmelerinden on yıllık uzama süresi dolmamış olmakla birlikte geri kalan süre beş yıldan daha kısa olanlar hakkında, yürürlüğe girdiği tarihten itibaren beş yıl; on yıllık uzama süresi dolmuş olanlar hakkında da yürürlüğe girdiği tarihten itibaren iki yıl sonra uygulanır". 


\section{konusu hükümlerin kiracıların aleyhine bir durum ortaya çıkardığg gerekçesiyle} Anayasa Mahkemesine iptal talebinde bulunulmuş, ancak Anayasa Mahkemesi 07.09.2016 tarihli kararıyla iptal başvurusunu reddetmiştir. Kararda on yıllık uzama süresi sonunda kiraya verenin kira sözleşmesini sona erdirme hakkı veren yasal düzenlemenin kiracılar aleyhine kamu düzenini bozmadığı ve sözleşme özgürlüğüne ölçüsüz bir müdahale de teşkil etmediği sonucuna varılmıştır ${ }^{13}$.

13 AYM 07.09.2016, 2015/102 E - 2016/151 K, (RG 18.10.2016 N.29861). Davacı kiraya veren tarafindan davalı kiracı aleyhine belirli süreli kira sözleşmesinde on yılllk uzama süresinin sonunda, kiraya veren tarafindan sözleşmeye son verilmesine rağmen taşınmazın kiracı tarafından tahliye edilmemesi nedeniyle açılan davada, Bodrum 2. Sulh Hukuk Mahkemesi'nce davalı kiracı tarafın Anayasa'ya aykırılık iddiaları ciddi bulunmuştur. Yerel Mahkeme tarafından Anayasa Mahkemesine yapılan başvuruda, 6098 sayılı TBK m.347/I, c.3 ve 347/II hükümlerinin, ayrıca Yürürlük K m.1/I, c.2'de yer alan “...sona erme ve tasfiye, Türk Borçlar Kanunu hükümlerine tabidir.” ibaresinin ve Yürürlük K Geçici m.2 hükmünün, Anayasa'nın 2., 6., 13., 35., 48. ve 173. maddelerine aykırılığı ileri sürülerek iptallerine karar verilmesi istenmiştir. Yerel mahkemenin başvuru kararında özetle, Kanun'un 347. maddesindeki düzenlemenin, özellikle kiralananı işyeri olarak kullanan kiracılar bakımından olumsuz sonuçlar doğurarak onları maddi ve manevi zarara uğratacağı, Türkiye'de konutların kiralanma oranları dikkate alındığında madde gerekçesinde ifade edilen kamu yararının bulunmadığı, Kanun'da kiraya verenin mülkiyet hakkının korunmasına yönelik çeşitli hükümlerin yer aldığı, düzenlemenin meşru amaç, hukukilik, demokratik toplum düzeninin gerekleri ve ölçülülük ilkelerine aykırılık teşkil ettiği, kiraya verenin sözleşmeye son vermesiyle esnaf veya tacir olan kiracının kiralanana yaptığı ya da yapmakta olduğu yatırımların karşılıksız kalacağı, söz konusu kişilerin işlerini başka yerde yeniden kurmak ve tanıtmak durumuyla karşıllaşabilecekleri, bu ve benzeri ağır durumların sözleşme hürriyetine ölçüsüz bir müdahale oluşturacağı belirtilerek kuralın, Anayasa'ya aykırı olduğu ileri sürülmüştür.

TBK m.347/II hükmünün dava konusu olayda uygulama yeri olmadığından iptali talebini reddeden Anayasa Mahkemesi, belirli süreli kiralara ilişkin TBK 347/I, c.3 yönünden yapılan iptal başvurusunu esastan inceleyerek, söz konusu hükmün Anayasa'ya aykırı olmadığına karar vermiştir. Anayasa Mahkemesinin gerekçesi şöyledir: “(...) Belirli süreli kira sözleşmelerinde kural, sürenin dolması halinde kiracının sözleşmeyi sona erdirebilmesidir. Buna karşılık, kanun koyucu kiraya verenin, kira süresinin bitimine dayanarak sözleşmeyi sonlandırabilmesine imkân tanımamıştır. Amaç, kiracının korunması ve bu suretle kamu yararının sağlanmasıdır. Bununla birlikte itiraz konusu kuralla, kiraya verene, sözleşme özgürlüğü gözetilerek, sözleşme süresi ve on yıllık uzama süresi dikkate alındiğında uzun bir süre için kiralanan şeye dolaysız zilyet olamaması nedeniyle belirli koşulların gerçekleşmesi halinde sözleşmeyi sona erdirme hakkı tanınmaktadır. Kuralla, kiracının korunmasındaki kamu yararı amacı ile kiraya verenin sözleşme özgürlüğ̈̈ arasındaki makul denge, kiraya verene herhangi bir sebebe dayanmaksızın sözleşmeyi sona erdirme hakkının, sözleşmenin bitiminden itibaren on yıllık uzama süresi sonunda sağlanmasıyla kurulmaya çalışılmıştır. Dolayısıyla sözleşme özgürlügüne yapılan müdahale ölçüsüz değildir (...)".

Yine Yürürlük kanunun hükümleri ile ilgili olarak ileri sürülen iptal talebini ise Anayasa Mahkemesi şu gerekçelerle reddetmiştir: “ (...) Kanun koyucu, önceki kanun döneminde kurulmuş ve etkilerini yeni kanun döneminde devam ettiren kira sözleşmelerinde tarafların iradelerine sayg l gösterilmesi ve hukuki güvenliğin sağlanması amacıyla "geçmişe etkili olmama kuralı" $n$ benimsemiş başka bir deyişle "eski kanunun uygulanması" ilkesini prensip olarak kabul etmiștir. "Sona erme" ibaresiyle sınırlı olarak esas incelemesi yapılan “...sona erme ve tasfiye, Türk Borçlar Kanunu hükümlerine tabidir." hükmü, eski Kanun döneminde kurulmuş bir sözleşmeyi geçersiz kılmamakta veya sona ermiş bir sözleşmeye müdahale etmemekte, hukuki sonuçlarını doğurmaya devam ettiren bir sözleşmenin sona ermesi yönünden yeni kanun hükümlerinin geçerli olmasını öngörmektedir. Kanun koyucu, sözleşmenin hukuk düzeninde etkilerini devam ettirdiği aşamalardan birini teşkil eden ve kuralda sınırl olarak incelemesi yapılan "sona erme" ibaresi yönünden, temerrüt ve tasfiyedeki gibi istisnai bir durum için yeni kanun hükümlerinin uygulanmasını benimsemiştir. 818 sayll mülga Borçlar Kanunu'nda bulunmayan, 6098 sayll Kanun'da yeni düzenlemeler içeren temerrüt, sona erme ve tasfiye için sözleşmenin önceki kanun döneminde yapılmış olması halinde de 6098 sayıl Türk Borçlar Kanunu hükümlerinin uygulanmasının öngörülmesi, kanun koyucunun takdir yetkisinin kapsamindadır.

Hukukî güvenlik ilkesi, değişen bir kuralın kişilere uygulanamamasını değil, mevcut kurallara güvenerek hareket eden kişinin bu nedenle öngöremediği, olumsuz sonuçlarla karşı karşıya kalmasını önlemeyi amaçlamaktadır. Kanun'un itiraz konusu kuralı oluşturan “...on ylllk uzama süresi dolmuş olanlar hakkında da yürürlüğe girdiği tarihten itibaren iki yıl...” bölümünün de yer aldığı geçici 2. maddesi, konuya ilişkin yeni kuralın derhal uygulanması halinde kiracıların karşılaşabilecekleri olası sorunların önlenmesi, zarara uğramamaları ve mağdur edilmemeleri için bir defaya mahsus olmak üzere 6098 sayll Kanun'un 347. maddesinin birinci fikrasının üçüncü cümlesinin yürürlüğe girmesini iki yll süreyle erteleyerek kiracıları koruma altına almaktadır. Böylece kira sözleşmelerinde kiracıların lehine bir düzenleme yapılmış ve kira sözleşmelerinde on yıllık uzama süresinin bu Kanun'un yürürlüğe girdiği tarihte dolmuş olması halinde kiraya verene tanınan sözleşmeyi sona erdirme hakkının kullanılmasının belli bir süre ertelenmesiyle kiracı ile kiraya verenin hakları arasında makul bir denge sağlanmaya çalışılmıştır.

6098 sayll Türk Borçlar Kanunu'nun 347. maddesinin birinci fikrasının üçüncü cümlesinde kiraya verene tanınan sözleşmeyi sona erdirme yetkisinin, Kanun'un yürürlüğe girdiği tarihte uygulanmasının mümkün olmaması ve bu konuda iki ylllk geçiş sürecinin öngörülmüş olması gözetildiğinde kuraldaki "sona erme" ibaresi yönünden "geçmişe etkili olmama kurall” uygulanmayarak yeni kanunun yürürlügünün kabul edilmesi hukuki güvenliği ve sözleşme özgürlügünü zedelememektedir". 


\section{Kanunda Düzenlenen On Yıllık Uzama Süresi Hakkında Lehte ve Aleyhte İleri Sürülen (De Lege Ferenda) Görüsşler}

Öğretide bir görüşe göre ${ }^{14}$, TBK m.347 hükmünde uzama süresinin on y1l olarak belirlenmiş olması, isabetli ve makuldür.

Başka bir görüşe göre ${ }^{15}$, kira süresinin on y1ldan daha uzun olduğu hallerde, olması gereken hukuk olarak, on yıllık uzama süresi, kira süresinin ilk on yılının bitiminden itibaren başlatılmalıdır.

Uzama süresinin on y1l olarak öngörülmesi, öğretide farklı yönlerde eleştiriye de uğramıştır. On yıllık uzama süresini eleştiren bir görüşe göre ${ }^{16}$ kanundaki belirli süreli konut ve çatılı işyeri kiralarına ilişkin uzama süresi beş yıllık bir zaman dilimiyle sınırlandırılmalıdır. Benzer yöndeki bir başka görüşe göre, uzama süresi azami konutlarda üç yıl; işyerlerinde beş yıl olmalı ve sürenin uzatılıp uzatılmayacağına, haklı sebeplerin varlığına bağlı olarak hâkim karar vermelidir ${ }^{17}$. Diğer bir görüşe göre $^{18}$ ise, olması gereken hukuk anlamında konut kiraları için uzama süresi, bildirim süresine uymak koşuluyla, beş yıl ile sınırlandırılmalı, çatılı işyeri kiraları için ise kanundaki on yıllık uzama süresi muhafaza edilmelidir. Ayrıca kiraya veren bu hakkını toplam süresi on beş yıllık üst süreye ulaşmış her türlü konut ve toplam süresi yirmi yıla ulaşmış her türlü çatılı işyeri kirasında aynı bildirim süresine uymak koşuluyla da kullanabilmelidir.

Diğer bir görüşe göre, TBK m.347 hükmü ile kiraya verene on y1llık uzama süresi sonunda sözleşmeyi sona erdirebilme yetkisi tanınması, kiracıyı koruma ilkesine ters düşer ${ }^{19}$, Anayasa'ya aykırıdır ${ }^{20}$ ve bir an evvel yürürlükten kaldırılmalıdır ${ }^{21}$.

${ }_{14}$ Halil Akkanat, "Kira Sözleşmesinin Sona Ermesi”, Türk Borçlar Kanunu Sempozyumu: Makaleler-Tebliğler, Ed. Murat İnceoğlu, Oniki Levha, İstanbul, 2012, s.267; İnceoğlu, II, s.329, 330, dn.568.

15 Murat Aydoğdu/ Nalan Kahveci, Türk Borçlar Hukuku Özel Borç İlişkileri: Sözleşmeler Hukuku, 3.Bask1, Adalet, Ankara, 2017. s.643, dn.1.

16 Eren, s.412; aynı yönde olmak üzere on yıllık uzama süresinin çok olduğu, en azından beş yıl şeklinde düzenlenmiş olsaydı daha isabetli olacağı yönünde: Abdülkadir Arpacı, "Yeni Borçlar Kanununun Getirdiği Değişiklikler”, İstanbul Barosu Staj Eğitim Merkezi, Cumartesi Forumları- 4, Ege Basım, İstanbul 2012, s.90-91; aynı yönde Nami Barlas, "Yeni Borçlar Kanunu Tasarısının Getirdikleri”, Güncel Hukuk Dergisi, S.17, 2005, s.20-22; Makalelerim, C.1, İstanbul 2008, s.267. Ne kadar süre olduğunu belirtmemekle birlikte, kanunda düzenlenen on yıllık uzama süresinin uzun olduğu için isabetsiz olduğu yönünde: Mustafa Özdoğan/ Tuba Oymak, 6098 sayılı Türk Borçlar Kanunu'nda Kira, Genel Hükümler, Konut ve Çatılı İşyeri Kirası, Tahliye, Bilge, Ankara 2013, s.532.

17 İbrahim Kaplan, "Borçlar Kanunu Tasarısı Hakkındaki Görüşlerim”, Terazi Hukuk Dergisi, S.25, Eylül 2008, s.34.

18 Demircioğlu, s.194-195, 196.

19 Ömer Sever, "Konut ve Çatılı İşyeri Kiralarında Sözleşmenin Sona Ermesi”, Hukuk ve Adalet Eleştirel Hukuk Dergisi, C.6, S.15, Legal, 2014, s.208.

20 Yaşar Köstekçi, Borçlar Hukuku ve Anayasa'ya Aykırılık Boyutlarıyla 10 Yıl Uzama Süresi Sonu Kiracının Tahliyesi, Tahliyeden Korunma Önlemleri, Vedat, İstanbul, 2014, s.155 vd. Gümüş’e göre de, TBK m.347/I, c.3, Anayasa'ya aykırılı̆̆g dahi tartışılabilir bir hükümdür (Armağan, s.138).

Buna karşılık, işyeri kiracılarının TBK m.347 hükmü ile mağdur olması sebebiyle açılan iptal davasında, Anayasa Mahkemesi'nin TBK m.347 hükmünü Anayasa'ya aykırı bulmadığına yukarıda değinmiştik. Bkz. dn.13.

21 Gümüş, Armağan, s.140-141. Yazar, ünlü ve tarihi işyerlerinin, kira sözleşmelerinin TBK m.347/I, c.3 ve m.347/II'de kiraya verene tanınan fesih hakkı sonucunda sonlandırılı̆̆ını ve böylece kültürel dokunun zarara uğradığını, kiraya verenin rantının korunmasının tercih edildiğini belirterek hükmü eleştirmektedir. 
Hükmü eleştiren bir başka görüşe göre ${ }^{22}$, belirli süreli kira sözleşmelerinde uzama süresi bakımından konut kiraları ile çatılı işyeri kiraları farklı değerlendirilmeli; aynı hükme tabi tutulmamalıdır. Çünkü çatılı işyeri kiralarında kiracı işyeri ile ilgili olarak ciddi yatırımlarda bulunmakta ve bir müşteri çevresi oluşturmaktadır. On yıllık uzama süresi sonunda çatılı işyeri kiracısının tahliye edilmesi, ekonomik olarak kiracının ciddi zarar görmesine yol açacaktır. Bu sebeple, on yıllık uzama süresi konut kiraları bakımından uygun görülebilirse de, çatılı işyeri kiraları bakımından on beş yıl gibi daha uzun bir süre getirilmelidir. Uzama süresi bakımından konut kiraları ile çatılı işyeri kiralarının farklı hükümlere tabi tutulması gerektiğini savunan diğer bir yazara göre ${ }^{23}$ ise, "TBK m. 347 gereğince kiraya verene yasadaki süreler geçtikten sonra sözleşmeyi sebepsiz sona erdirme imkânının işyeri kiraları bakımından uygulanmaması gerekir". Ancak bu görüşler, öğretide, önemli yatırımlar yapan ya da müşteri çevresini korumak isteyen bir işyeri kiracısının ilk kira sözleşmesini bir yıldan uzun süreli yapması gerektiği ve bu sebeple on yıllık uzama süresinin işyeri kiraları bakımından kısa olduğu yönündeki görüşlerin isabetli olmadığı yönünde eleştirilmiştir ${ }^{24}$.

Diğer bir görüşe göre ${ }^{25}$, işyerini tahliye eden kiracının benzer bir işyeri bulması her zaman mümkün olmadığından, işyeri kiralarında on yılın sonunda kiraya verenin sözleşmeyi feshetmekte korunmaya değer bir menfaati ya da haklı bir sebebi yoksa

22 Doğan/Baygın, s.129; Bülent Nuri Kurdoğlu, “Türk Borçlar Kanunu Tasarısının İncelenmesi, Ankara Barosu Dergisi, 2005/3, s.73; Doğan, Sona Erme, s.64; Murat Doğan, “6098 Sayılı Türk Borçlar Kanununa Göre Konut ve Çatılı İşyeri Kiralarına İlişkin Hükümlerinin Değerlendirilmesi”, Prof.Dr. Cevdet YAVUZ’a Armağan, Marmara Üniversitesi Hukuk Fakültesi - Hukuki Araştırmalar Dergisi, Özel Hukuk Sempozyumu Özel Sayısı: 6098 Sayılı Türk Borçlar Kanunu Hükümlerinin Değerlendirilmesi Sempozyumu (3-4 Haziran 2011), Sempozyum No: III, 2011, s. 515.

Çatılı işyeri kiraları bakımından, TBK m.323/I'de konut kiralarına nazaran farklı bir hüküm getirilmektedir: Hükme göre: "Kiracı, kiraya verenin yazılı rızasını almadıkça, kira iliş̧isini başkasına devredemez. Kiraya veren, işyeri kiralarında haklı sebep olmadıkça bu rızayı vermekten kaçınamaz". Olması gereken hukuk anlamında, çatılı işyeri kiraları ile konut kiraları arasında, tıpkı TBK m.323/I'de olduğu gibi, benzer bir ayrımın, TBK m.347'deki uzama süresi açısından da yapılması gerektiği görüşünde: Doğan/Baygın, s.129; Doğan, Sona Erme, s.64.

23 Ahmet Türkmen, "6098 Sayılı Türk Borçlar Kanunu'nun Kira Sözleşmesine İlişkin Yürürlüğü Ertelenen Hükümlerin Değerlendirilmesi”, Ankara Barosu Dergisi, 2015/1, s.366. Yazara göre, kanunda öngörülen "konut- çatılı işyeri ayrımı" rasyonel değildir. İşyeri kiracılarının korunması bakımından işyerlerinin kendisine özgü bazı niteliklerinin (imaj, müşteri çevresi, goodwill, sabit tesisat gibi maddi ve gayri maddi ekonomik değerlerin), tıpkı işyeri kirasının devrinde olduğu gibidikkate alınması ve buna göre koruyucu haklar tanıyan bir yasal düzenlemenin yapılması gerekmektedir (s.343, 366).

24 İnceoğlu, II, s.330, dn.568.

25 Şahin Akıncı, "İşyeri Kiralarında Kiracının Korunması Açısından Borçlar Kanunu Tasarısının Bazı Hükümlerinin Değerlendirilmesi”, Ankara Üniversitesi Hukuk Fakültesi Dergisi, C.57, S.3, 2008, s.47-48: "Tasarının 353. maddesinde getirilen 15 yıllık sürenin sonunda -(tasarıdaki 15 yıllık süre hüküm kanunlaşırken on yıla indirilmiştir)- kiralayanın sebep göstermeksizin sözleşmeye son verebileceğine ilişkin hüküm mesken kiraları açısından isabetlidir. Çünkü tahliye sebepleri gerçekleşmediği müddetçe kiralayanın sözleşme ile bağlı kalması ve sürenin çok uzaması, mülkiyet hakkının özüne dokunan bir kısıtlama halini alabilmektedir. Bir meskende kiracı olarak (on) yll oturan bir kimsenin bu sürenin sonunda eşdeğer bir meskeni kiralama imkânı da çoğunlukla mevcuttur. Fakat işyeri kiraları için farklı düşünmek gerekir. Çünkü işyerini tahliye eden kiracının benzer bir işyeri bulması her zaman mümkün olmayabilmektedir. Bu nedenle işyeri kiralarında (on) yılın sonunda ĕ̆er kiralayanın tahliyeyi istemekte korunmaya lâyı bir menfaati ya da haklı bir sebebi yoksa kiracıya, taşınmazı bir yll daha tercihan kiralama hakks tanınmalıdır. Özellikle kiralanan, kiralayan tarafindan yeniden kiraya verilecekse, kiracı o zamana kadar borçlarını gereği gibi yerine getirmiş, yeni dönem için uygun bir kira bedeli de önermişse, tahliye için hakl sebebin ve korunmaya lâyık bir menfaatin olmadı̆̆g kabul edilmelidir. Kiralayanın kiracıdan bıkması tahliye için yeterli bir sebep sayllmamalıdır. Fakat kiralanan taşınmaza üçüncü kişiler tarafindan kiracının yeni dönem için önerdiğinden daha yüksek bir bedel önerilmiş ve kiracı üçüncü kişiler tarafindan önerilen bu bedeli ödemeyi kabul etmemişse (on) yılın sonunda kiralayanın tahliye davası açmakta haklı bir menfaatinin bulunduğunu kabul etmek gerekir. Çünkü böyle bir durumda kiralananı daha yüksek bir bedel ile kiraya verme imkânı bulunmaktadır". 
kiracının bir yıl daha tercihan kira sözleşmesini devam ettirme hakkı olmalıdır. Kiraya verenin kiralananı yeniden kiraya vereceği hallerde, kiracı borçlarını gereği gibi ifa etmişse ve üçüncü kişilerin işyerini kiralamak için önerdiği bedeli ödemeyi kabul ediyorsa, bir yıl daha kira sözleşmesini devam ettirebilme hakkına sahip olmalıdır ${ }^{26}$.

Diğer bir görüşe göre ${ }^{27}$, konut kiraları ve çatılı işyeri kiralarının bir ayrım yapılmaksızın aynı şekilde TBK m.347'de öngörülen emredici düzenlemeye tabi tutulmaları isabetli olmamıştır. İşyeri kiraları açısından emredici bir kural ile düzenlemeye ihtiyaç yoktur. Kiracısı tacir olan işyeri kiraları açısından on yıllık uzama süresine ilişkin hüküm aynen kalabilir veya hatta kira süresi sonundaki uzama yılının bitiminde kiraya verene fesih yetkisi verilebilir. Ancak konut kiraları ile kiracısının esnaf olduğu işyeri kiraları açısından kiraya verenin sebepsiz fesih hakkının emredici bir düzenlemeye tabi tutulması gerekir. Bununla birlikte, konut kiraları ile kiracısının esnaf olduğu işyeri kiraları bakımından on yıllık uzama süresinin sonunda kiraya verene tanınan fesih yetkisi isabetsiz olmuştur. Konut kiraları ve kiracısının esnaf olduğu işyeri kiraları açısından, on yıllık uzama süresi sonunda kiraya verene tanınan fesih yetkisi kaldırılmalıdır ya da hâkime takdir yetkisi veren bir düzenleme yapılmalidir.

\section{Belirli Süreli Konut ve Çatılı İşyeri Kira Sözleşmelerinde On Yıllık Uzama Süresinin Bașlangıcı}

Belirli süreli konut ve çatılı işyeri kiralarında on yıllık uzama süresinin ne zaman başlayacağ 1 konusunda öğretide farklı görüşler vardır. Yargıtay da, yeni Borçlar Kanununun yürürlüğe girdiği 2012 yılından günümüze kadar, aşağıda görüleceği üzere, belirli bir yönde içtihat oluşturmuştur.

Belirli süreli konut ve çatılı işyeri kiralarının kiraya veren tarafından bildirim yoluyla sona erdirilmesi için kanunda aranan “on yıllık uzama süresi”nin dolmuş olması koşulu, öğretide tereddütleri de beraberinde getirmiştir. On yıllık uzama süresinin, kira sözleşmesinin başından itibaren mi hesaplanacağı, yoksa kira süresinin ilk yllının bitimini takip eden bir zaman dilimi mi olduğu, yoksa uzama süresinin, kira sözleşmesinin süresinin sona ermesinden itibaren mi başlayacağı tartı̧̧malıdır.

\section{A. Öğretide Azınlıkta Kalan Görüşler}

Öğretide azınlıkta kalan görüşlerden birisi, sözleşmede öngörülen kira süresinin, on yıllık uzama süresine dâhil edilmesi gerektiği yönündeyken; diğer bir görüş,

\footnotetext{
26 Akıncı'ya göre, "istihdam politikalarının yetersiz, kayıt dışı ekonominin geniş ve işsizliğin yaygın olduğu ülkemizde, müteşebbisi caydırıcı bütün unsurların ortadan kaldırlması gerekir. (...) Kira sözleşmelerinin kısa süreli olması, müteşebbis açısından caydırıcı bir rol oynamaktadır. Bu nedenle, işyeri kiralarında uzun süreli kira sözleşmesi yapma imkânının kiracılara tanınmasında, kiracının korunmasının yanı sıra, kamu yararının olduğunu dahi söyleyebiliriz” (s.38).

27 Sanl, s.135-136, 139.
} 
kiraya verenin kira süresinin başlangıcından itibaren toplamda on ikinci yılın sonunda sözleşmeyi sona erdirebileceği yönündedir.

\title{
1. Kira Süresinin, On Yıllık Uzama Süresinin Hesabına Dâhil Edilmesi Ge- rektiği Görüşü
}

Bu görüştekilere göre ${ }^{28}$, sözleşmede öngörülen kira süresi, on yıllık uzama süresine dâhil edilmelidir; böylece on y1llık süre, sözleşmenin hükümlerini doğurmaya başladığı kira süresinin başlangıcı anından itibaren işlemeye başlayacaktır.

\begin{abstract}
Zevkliler/Gökyayla'ya göre, kanun metninde geçen "on yıllık uzama süresini izleyen" ifadesi, "soyut nitelikte; yasanın amacının ötesine geçen; yasa maddesinin kendi içinde olduğu gibi diğer maddelerinin hükümleri ile de çelişebilecek olan; uygulamada belirsizlik ve eşitsizliklere, dolaylslyla duraksamalara yol açacak bir ifadedir. (...) On ylllık sürenin başlangıcının, hangi tarih esas alınarak hesaplanacağı düzenlemeden anlaşılamamaktadır. Yasa maddesinin gerekçesinde de bu konuya açılklk getirici bir ifade bulunmamaktadır (...)" ${ }^{29}$.
\end{abstract}

Bu görüşün dayandığg gerekçelerden ilki, kira süresinin on yılın hesabına dâhil edilmemesi durumunda kanunun amacıyla bağdaşmayan sonuçların doğacağıdır. Zira her bir belirli süreli kira sözleşmesinde kira süreleri farklı kararlaştırılabilir ve bu da her bir sözleşmenin, on yıllık süre de ilave edilmek suretiyle, farklı tarihte sona ereceği anlamına gelir. Örneğin bir yıllık bir kira sözleşmesi en erken on ikinci yılın sonunda sona ererken, alt yıllık kira sözleşmesi, on yedinci yılın sonunda ve on beş yıllık bir kira sözleşmesi ise yirmi altıncı yılın sonunda sona erecektir. Oysa kanunda amaçlanan sonuç (ratio legis) böyle değildir. Kanunun amacı dikkate alındığında, kiraya verenin sözleşme özgürlüğü gereğinden fazla sınırlandırılmamalı ve kiraya verenin menfaatleri göz ardı edilmemelidir. Kanun koyucu makul bir süre olarak on yılı benimsemiştir; on yılın aşılması, kiraya verenin menfaatlerinin göz ardı edilmesi ve kiraya verenin, kiracının boyunduruğu altına girmesi anlamına gelecektir ${ }^{30}$.

\footnotetext{
28 Doğan, Sona Erme, s.63; Aydın Zevkliler/ K. Emre Gökyayla, Borçlar Hukuku Özel Borç İlişkileri, 18. Bası, Turhan, Ankara 2018, s.340 vd; Gümüş, Kira Sözleşmesi, s.312-313; Mustafa Alper Gümüş, Borçlar Hukuku Özel Hükümler C.I, 3. Bası, Vedat Kitapçılık, İstanbul 2013, s.336; Gümüș, Armağan, s.122-123; Efrail Aydemir, Türk Borçlar Yasasına Göre Kira Hukuku, 4.Baskı, Seçkin, Ankara 2016, s.79; Mehmet Öztürk, "Konut ve Çatılı İşyeri Kira Sözleşmelerinin Sona Erme Halleri”, Dokuz Eylül Üniversitesi (D.E.Ü) Hukuk Fakültesi Dergisi, Prof. Dr. Şeref Ertaş’a Armağan, C.19, Özel Sayı, 2017s.1555-1556; Tuba Birinci Uzun, "Belirli Süreli Konut ve Çatılı İşyeri Kira Sözleşmelerinin Kiraya Veren Tarafından Bildirim Yoluyla Sona Erdirilmesinde On Yıllık Uzama Süresi (TBK md. 347 f.1)”, İnönü Üniversitesi Hukuk Fakültesi Dergisi, C.8, S.2, 2017, s.151-152; Mehmet Remzi/Sezer Aydın, Borçlar Hukuku Özel Hükümler, 8.Bas1, İkinci Sayfa, 2017, s.169 (Ancak yazarlar, on yılın bitiminden itibaren takip eden uzama yılının sonunda (on birinci yılın sonunda) sözleşmenin sona ereceği görüşündedirler).

Olması gereken hukuk anlamında, on yıllık sürenin hesabına kira süresinin de dâhil edilmesi gerektiği görüşünde olmakla birlikte, yürürlükte olan hukuk bakımından kanundan böyle bir anlam çıkmayacağı görüşünde: Nihat Yavuz, Yeni TBK, HMK, İ̈K ve İstinafa Göre Kira Hukuku, 6.Baskı, Adalet, Ankara, 2018, s.664. (Yazar, örnek olarak 8 y1llık bir kira sözleşmesinin 2 yıl sonra, 12 yıllık bir kira sözleşmesinin ise 12 yılın sonunda kiraya veren tarafından sona erdirilebileceğini belirtmektedir. Yazarın s.665’te verdiği bu örnekler, herhalde olması gereken hukuk açısından savunduğu görüșü açıklamak için verilmiş olsa gerektir. Zira yazar, daha önce (s.664'te) yürürlükteki hukuk açısından kira süresi + on uzama y1lı +1 uzama yılı sonunda sözleşmenin kiraya veren tarafından feshedilebileceği görüşünde olduğunu belirtmiştir.

29 Zevkliler/Gökyayla, s.340.

30 Zevkliler/Gökyayla, s.340-341; Birinci Uzun, s.152.
} 
İkinci olarak, kira süresinin on yılın hesabına dâhil edilmemesi durumunda, kiraya verenin sözleşme özgürlüğü, her bir kira sözleşmesi için farklı zaman dilimlerinde ve on yıldan fazla bir süreyle uzun y1llar boyunca sinırlanabilecektir ki, bu durum Türk Medeni Kanununun (TMK) 23.maddesinin 2.fikrası hükmünün temelinde yatan amaca aykırılık teşkil eder ${ }^{31}$. TMK m.23/II gereğince, "Kimse özgürlüklerinden vazgeçemez veya onları hukuka ya da ahlâka aykırı olarak sınılayamaz". Nitekim mülga eBK m.343 (TBK m.430/III) hükmünde de on yıldan uzun süreli hizmet sözleşmelerinin, on yılın sonunda feshedilebilmesine ilişkin düzenlemenin temelinde de aynı düşünce yatmaktadır ${ }^{32}$. Nitekim TBK m.598/III hükmünde gerçek kişi tarafından verilen kefaletlerin sözleşmenin kurulması anından itibaren on yıl sonra sona ereceği hükmü de aynı düşüncenin bir başka somut örneğidir ${ }^{33}$.

Üçüncü olarak, kira süresinin on yılın hesabına dâhil edilmemesi halinde, belirli kira sözleşmesinin sona ermesine ilişkin TBK m.347/I, c.3 hükmü ile belirsiz süreli kira sözleşmesinin sona ermesini düzenleyen TBK m.347/II hükmü, birbiriyle çelişecek ve bu durum kanunun amacına (ratio legis'e) uygun düşmeyecektir. Çünkü TBK m.347/II'ye göre belirsiz süreli kira sözleşmeleri bakımından on yıllık sürenin başlangıcı, kira sözleşmesinin hükümlerini doğurmaya başladığı an olarak açıkça düzenlenmiş̧tir. Buna karşılık TBK m.347/I, c.3 hükmünde on yıllık sürenin ne zaman işlemeye başlayacağı konusunda hem madde metninde hem de gerekçede belirsizlik vardır. Her iki hüküm de kiraya verene on yılın sonunda kira sözleşmesini fesih hakkı tanımaktadır; kiraya verenin kira sözleşmesiyle bağlı kalacağı üst sürenin on yıl olması amaçlanmıştır. Öyleyse belirli süreli kira sözleşmeleri ile belirsiz süreli kira sözleşmeleri arasında bir fark yaratmak ve belirli süreli kira sözleşmelerinde kiracıyı daha fazla korumak için bir sebep bulunmamaktadır ve aksine bir düşünce, kanun koyucunun amacına (ratio legis'e) ters düşer ${ }^{34}$.

Belirli süreli konut ve çatılı işyeri kiralarına ilişkin olarak on yıllık uzama süresinin başlangıcı bakımından TBK m.347/I, c.3 hükmünde söz konusu olan belirsizlik, kira sözleşmesinin "genel hükümleri” arasında yer alan ve belirsiz süreli kira sözleşmelerinin sona erdirilmesini düzenleyen TBK m.328/I, c.2 hükmü ile giderilebiliri35. TBK m.328/I, c.2 gereğince, "Fesih dönemlerinin hesabında, kira sözleşmesinin başlangıç tarihi esas alını"'.

\footnotetext{
31 Zevkliler/Gökyayla, s.342; aynı yönde Birinci Uzun, s.153 (Buna karşı1ık yazar, on yıldan daha uzun süreli sözleşmeler akdedilmesi halinde kısmi hükümsüzlük yaptırımının uygulanıp uygulanmayacağı konusunda görüş beyan etmemiştir). Zevkliler/Gökyayla'ya göre, “4721 sayıl TMK'nın 23/II.maddesi hükmü göz önünde tutularak, 818 sayll BK m.343 hükmünün bir benzerine TBK 347/I.maddesinde yer verilmiş olma ihtimali bulunmakla birlikte, bu kez de burada değinilen sakıncalara yol açacak ifadelere ve yetersiz ve eksik bir gerekçeye yer verilmiştir" (s.342).

32 eBK m.343'de on yılın sonunda işçiye feshetme imkânı tanındığı maddede ifade edilmişken; TBK m.430/III hükmündün madde metninde ise on yılın sonunda her iki tarafça da hizmet sözleşmesinin feshedilebileceği hükmüne yer verilmiştir.

33 Zevkliler/Gökyayla, s.342.

34 Zevkliler/Gökyayla, s.343; Birinci Uzun, s.154.

35 Zevkliler/Gökyayla, s.343-344.
} 


\section{Kiraya Verenin Toplamda On İkinci Yılın Sonunda Sözleşmeyi Sona Erdirebileceği Görüşü}

Yavuz/Acar/Özen'e göre ${ }^{36}$, kanun koyucu TBK m.347/I, c.3'deki süreleri ihdas ederken, bir kira yılı + on uzama yılı + takip eden bir uzama y1lı şeklinde bir sistemi esas almış; böylece kiracı yalnızca on iki yıl süre ile korunurken, kiraya verene sözleşmenin on üçüncü yıla uzamamasını sağlama imkânı tanınmıştır. Kira süresi bir yıldan uzun olsa bile, "kiracının on iki yıl korunması sistemi" gereğince kira süresinin yalnızca ilk yılı hesaplamada nazara alınmalıdır ${ }^{37}$. Buna göre, örneğin sekiz yıllık bir kira sözleşmesinde, kiraya veren, en az dört yıl daha ( 8 yıl +3 uzama yılı +1 takip eden uzama yılı) beklemek zorunda olup, dördüncü yılın bitimine en az üç ay kala yapacağı bildirimle sözleşmeyi feshedebilecektir. Çünkü kanun koyucu, kiracıyı on y1l için korumuş ve on ikinci yılın sonu itibariyle kiraya verene fesih hakkı tanımıştır.

Kira süresinin sona ermesinden itibaren on yıl geçtikten sonra en erken takip eden uzama yılında kiraya verenin fesih bildiriminde bulunabileceğini kabul etmek, haksız sonuçlar doğurabilir. Kanun koyucu, gerekçede, söz konusu süreleri belirlerken, onlarca yıl süren kira ilişkileri sebebiyle kiraya verenlerin mağdur olmasını engellemek ve toplumsal huzursuzlukları gidermek maksadıyla düzenleme getirdiğini açıklamışken, kira süresinin sona ermesinden itibaren on yılın başlamasını kabul etmek, kanun koyucunun amacina ters düşer ve toplumsal huzursuzluk önlenmiş olmaz.

Buna karşılık on yıldan daha uzun süreli kira sözleşmeleri bakımından, kiraya verenin kira süresi dolmadan sözleşmeyi feshetmesi mümkün değildir. Çünkü kiraya veren kendi iradesiyle uzun süreli bir kira sözleşmesi akdettiğine göre, sözleşmeyle bağl11ık ilkesi uyarınca, kira süresinin sonuna kadar beklemek zorundadır. Örneğin on beş y1llık bir kira sözleşmesinde kiraya veren, on ikinci y1lın sonunda değil; en erken on beşinci yılın sonunda -elbette en az üç ay önceden yapacağı bildirim ilesözleşmeyi feshedebilir ${ }^{38}$.

\section{B. Öğretide Hâkim Görüş ve Yargıtay Uygulaması: Kira Süresinin, On Yıllık Uzama Süresinin Hesabına Dâhil Edilmemesi Gerektiği Görüşü}

Hâkim görüşe göre ${ }^{39}$, on yıllık uzama süresi, sözleşme ile kararlaştırılan kira

Yavuz/Acar/Özen, s.660-661. Sayın Prof. Dr. Cevdet Yavuz, Türk Borçlar Kanununun hazırlık çalışmalarında Komisyonda görev almıştır.

${ }^{37}$ Karşı görüşte Burcuoğlu, Quo Vadis, s.43. Sayın Prof. Dr. Haluk Burcuoğlu, Türk Borçlar Kanununun Hazırlık Çalışmalarında Komisyonda görev almıştır.

38 Yavuz/Acar/Özen, on iki yıllık bir kira süresi örneğinden hareket ederek, on birinci yılın sonunda kiraya verenin sözleşmeyi feshedemeyeceğini ifade etmekte iseler de, yazarlar on iki yıllık bir sistemi esas aldıklarına göre, on iki yıldan daha uzun süreli sözleşme örnekleri ile bu görüş daha iyi anlaşılabilir. Aynı yönde: Aylin Hekim, Konut ve Çatılı İşyeri Kira Sözleșmelerinin Bildirim Yoluyla Sona Ermesi (TBK m. 347), Yayınlanmamıș Yüksek Lisans Tezi, İstanbul Üniversitesi Sosyal Bilimler Enstitüsü Özel Hukuk Anabilim Dalı, İstanbul 2018, s.67-68.

39 Haluk Burcuoğlu, “Borçlar Kanunu Tasarısı'nın Haksız Eylem Sorumluluğu ve Kira İle İlgili Düzenlemesiyle Getirilen Yenilikler”, Prof. Dr. Turgut Akıntürk’e Armağan, Beta, Ankara, 2008, s.36; Haluk Burcuoğlu, in “Seminer: Borçlar Kanuna 
süresinin bitiminden itibaren başlar. Buna göre, kiraya veren, sözleşmeyi sebep göstermeksizin feshetme hakkını, kira süresini müteakiben işleyecek on yıllık uzama süresinin tamamlanmasının ardından işlemeye başlayacak olan her bir yıllık uzama yılının bitiminden en az üç ay önce yapacağı bildirim ile kullanma imkânına sahiptir (Kira süresi + on y1llık uzama süresi + ( en az) bir y1llık uzama süresi). Kira sözleşmesi, fesih hakkının kullanıldığı uzama yılının sonundan itibaren feshedilmiş sayılır. Örneğin 5 yıllık bir kira sözleşmesi yapılmışsa, kiraya veren, süresinde fesih bildiriminde bulunmuş olmak kaydıyla, en erken 16. kira yılının bitiminden itibaren (5 yıl kira süresi +10 uzama yılı +1 uzama yılı) sözleşmeyi feshedebilir ${ }^{40}$.

On yıllık uzama süresinin başlangıcı hakkındaki Yargıtay uygulaması, öğretideki hâkim görüş doğrultusundadır; Yargıtay’a göre, on yıllık uzama süresi, kira süresinin bitiminden itibaren başlar ${ }^{41}$.

\section{Genel olarak on yıllık uzama süresinin, taraflarca kararlaştırılan kira süresinin} tamamlanmasından itibaren başlayacağını kabul eden hâkim görüşün ilk dayanağ1,

Getirilen Yenilikler” (Prof. Dr. Haluk Burcuoğlu - Prof. Dr. Atilla Altop Yrd. Doç. Dr. Ebru Ceylan - Av. Umut Yeniocak Av. Tamer Şahin), İzmir Barosu Dergisi, C.77, S.2, 2012, s.67; Burcuoğlu, Quo Vadis, s.39, 43-44, 50; Gökhan Antalya, "Türk Borçlar Kanunu Tasarısının Değerlendirilmesi Sempozyumu, Dördüncü Oturum: Kira Sözleşmesi ve Kefalet, Legal Hukuk Dergisi, C.3, S.34, 2005, s.3701; İnceoğlu, II, s.333 vd; Turgut Öz, Yeni Borçlar Kanununun Getirdiği Başlıca Değişiklikler ve Yenilikler, 3. Bası, Vedat, İstanbul 2012 s.75-76; Mithat Ceran, Kira Sözleşmeleri Tahliye ve Tesbit Davaları, 2.Baskı, Yetkin, Ankara, 2015, s.90; Akyiğit, s.169; Ahu Ayanoğlu Moralı, "Konut ve Çatılı İşyeri Kiralarında Kiraya Verenin TBK m.347 Çerçevesinde Kira Sözleşmesini Bildirim Yoluyla Sona Erdirmesi”, Bahçeşehir Üniversitesi Hukuk Fakültesi Kazancı Hakemli Hukuk Dergisi, C.9, S.103-104, 2013, s.114; Ayanoğlu Moralı, Şerh, N.30, 37-38; Köstekçi, s.72-73; Aydoğdu/Kahveci, s.642 vd; Nil Karabağ Bulut, Medeni Kanunun 23. Maddesi Kapsamında Kişilik Hakkının Sözleşme Özgürlüğüne Etkisi, 1. Bası, On İki Levha Yayınları, İstanbul, 2014, s.146; Sanlı, s.108-109, 140; Doğan Şenyüz, Borçlar Hukuku: Genel ve Özel Hükümler, 8.Bası, Ekin, Bursa, 2016, s.353-354; Nihat Yavuz, 6098 Sayılı Türk Borçlar Kanunu'nun Getirdiği Değişiklikler ve Yenilikler (Genel Hükümler-Özel Hükümler), 3. Bası, Adalet Yayınevi, Ankara 2012, s.554; Nihat Yavuz, Borçlar Hukuku El Kitabı, Adalet, Ankara, 2018, s.978; N.Yavuz, Kira Hukuku, s.664 (Yazar, olması gereken hukuk anlamında, on yıllık sürenin hesabına kira süresinin de dâhil edilmesi gerektiği görüşünde olmakla birlikte, yürürlükte olan hukuk bakımından kanundan böyle bir anlam çıkmayacağı görüşündedir, ayrıca bkz. yukarıda dn.28); Sever, s.209; Merve Akgün Akay, Konut ve Çatılı İşyeri Kira Sözleşmelerine Özgü Sona Erme Sebepleri, Seçkin, Ankara 2017, s.24 (Yazar, on yıllık uzama süresinin "kira sözleşmesinin" bitiminden itibaren başlayacağını ifade etmekle birlikte, "kira süresinin" sona ermesinden itibaren işlemeye başlayacağı görüşünde olduğu anlatılmak istenmektedir); Pelin Kurşat, Konut ve Çatılı İşyeri Kira Sözleşmesinin Bildirim Yoluyla Sona Erdirilmesi, Filiz, İstanbul, 2017, s.47; Demircioğlu, s.191, 194 (ancak yazar, olması gereken hukuk anlamında konut kiraları açısından uzama süresinin beş yılla sınırlandırılması, işyeri kiraları açısından ise on yıllık sürenin muhafaza edilmesi gerektiği görüşündedir, bkz. s.194-195); Hekim, s.68.

Ayrıca bkz ve karş. Mithat Ceran, "6098 Sayılı Türk Borçlar Kanunu'nda Kira Sözleșmesi”, 6098 Sayılı Türk Borçlar Kanunu Sempozyumu, 12-13 Mayıs 2011, Ankara Barosu, Ed. Emel Badur, Salmat Basım Yayım, Ankara 2011, s.150; Mithat Ceran, “6098 Sayılı Türk Borçlar Kanunu'nda Kira Sözleşmesi”, Hukuk Muhakemeleri Kanunu ve Borçlar Kanunu Sempozyumu, 24-25 Mart 2011, Ankara Barosu, Ed. Emel Badur, Başak Matbaacılık, Ankara 2011, s.244. (Ancak yazar bu eserlerde on yıllık uzama süresinin başlangıç anı konusunda açık görüş beyan etmemektedir).

40 On yıllık uzama süresinin, kira süresinin bitiminden itibaren başlayacağını kabul etmekle birlikte, kiraya verenin fesih bildiriminde bulunabileceği en erken zaman dilimi açısından farklı görüşte: Akyiğit, s.169. Bu görüş için bkz. §IV, dn.62.

41 Y.6HD 19.11.2015, 6590/10095: “(...) taraflar arasındaki kira sözleşmesi 01/01/2000 başlangıç tarihli olup 7 yll sürelidir uzama süresi 01/01/2007 yllından itibaren başlatılması gerekir. Bu durumda uzayan dönem 01/01/2017 yllında sona ereceğinden ancak bu tarihten sonraki dönem için kiralananın süre bitimi nedeniyle tahliyesi istenebilir" (Lexpera). Y.6HD 13.10.2015,5805/8411: “(...) kiralanan TBK.nun konut ve çatılı işyeri kirası hükümlerine tabi olup, taraflar arasında imzalanan 01/10/2001 başlangıç tarihli 3 yll süreli kira sözleşmesinin süresi 01/10/2004 tarihinde sona erdiğinden bu tarihten sonra TBK.nun 347/1 maddesine göre kiracı tarafindan sözleşmenin bitiminden en az onbeş gün önce bildirimde bulunulmadığı takdirde kira sözleşmesi aynı şartlarda birer yll uzayarak on ylllı uzama süresi 01/10/2014 tarihinde sona erecektir. TBK 347/1 maddesi gereğince 10 yıllık uzama süresinin 01/10/2004 tarihinden bașlatılması gerekirken 01/10/2001 tarihinden başlatılması ve buna göre sonuca gidilmesi doğru değildir" (Lexpera). Aynı yönde; Y.3HD 05.12.2017, 9404/17034 (Kazanc1 İB); Y.3HD 06.02.2017, $1437 / 793$ (Kazanc1 IBB); Y.6HD 23.05.2016, 11403/4059 (Kazanc1 İBB); Y.6HD 22.2.2016, 9211/1178 (Kazanc1 İBB); Y.6HD 08.02.2016, $8957 / 680$ (Kazanc1 İBB);_Y.6HD 28.01.2016, 3643/537 (Kazanc1 İBB); Y.6HD 26.01.2016, 9169/401 (Lexpera); Y.6HD 19.06.2014, 5641/8167 (Kazanc1 İBB) 
bizzat hükmün açık lafzıdır ${ }^{42}$. Zira TBK m.347/I, c.1 hükmünde, konut ve çatılı işyeri kiralarında kiracının, belirli süreli kira sözleşmesini fesih bildirimi ile (olağan fesih) sona erdirme imkânı düzenlenmektedir. Buna göre kiracının, kira süresinin bitiminden en az on beş gün önce hiç veya usulüne uygun surette bir fesih bildiriminde bulunmaması halinde, sözleşmenin aynı koşullarla bir yıl için uzayacağı, kanun metninde "uzatılmış sayılır" ifadesiyle açıklanmış; böylece uzama süresi düzenlenmiştir. Maddenin takip eden üçüncü cümlesinde ise bu kez kiraya verenin belirli süreli konut ve çatılı iş yeri kirasını fesih bildirimi (olağan fesih) yoluyla sona erdirme imkânı düzenlenmektedir. Kiraya verenin olağan fesih hakkının doğması için gerekli olan koşullar, TBK m.347/I, c.3’te açıklanırken, "uzama süresi” ifadesi kullanılarak, aslında hükmün birinci cümlesindeki "uzatılmış sayılır" ifadesine gönderme yapılmaktadır. Üçüncü cümleye göre, “(...) on ylllı uzama süresi sonunda kiraya veren, bu süreyi izleyen her uzama yllnnn bitiminden en az üç ay önce bildirimde bulunmak koşuluyla, herhangi bir sebep göstermeksizin sözleşmeye son verebilir"'³. Açıklanan bu sebeplerle, bu görüşteki yazarlara göre, belirli süreli konut ve çatılı işyeri kiralarına ilişkin TBK m.347/I, c.3'te on yıllık uzama süresinin başlangıcının kanunda açık olmadığı yönündeki görüş ya da kira süresinin ilk yılının bitiminden itibaren on yıllık uzama süresinin başlayacağ yönündeki görüş, isabetli değildir. Nitekim Burcuoğlu'ya göre, "Sözleşme için öngörülmüş süre dolmadan, uzama süresinden söz etmek kesinlikle mümkün değildir" ${ }^{\prime 4}$.

İkinci bir dayanak olarak, kanun koyucunun, TBK m.347 hükmünde on y1llık uzama süresi bakımından, belirli süreli konut ve çatılı işyeri kiraları ile belirsiz süreli konut ve çatılı işyeri kiralarını ayrı ayrı düzenlemiş olmasına (f.1 ve f.2) işaret edilmiştir. Kanunda, belirli süreli konut ve çatılı işyeri kiralarının kira süresinin bitiminde itibaren işlemeye başlayacağı açıkça ifade edilmiş iken; belirsiz süreli olanların, kira başlangıcından itibaren işlemeye başlayacağı açıkça ifade edilmiş̧ir. Esasen kanundaki bu ayrım olağandır. Çünkü belirsiz süreli sözleşmeler bakımından, taraflar önceden bir kira süresi öngörmüş olmadığından, bir “uzama süresi”nden söz etmek de mümkün değildir. Bu sebeple de belirsiz süreli sözleşmelerde on yıllık uzama süresinin, kira süresinin bitiminden itibaren başlayacağını öngören kanun koyucu, belirsiz kira sözleşmeleri bakımından zorunlu olarak sözleşmenin başlangıç anının esas almıştır. Kanun koyucu, belirli süreli ile belirsiz süreli sözleşmeleri aynı hükümlere tabi tutmak isteseydi veya her ikisi için de on yıllık uzama süresinin kira süresinin başlangıcından itibaren başlamasını arzu etseydi, konuyu maddenin farklı

\footnotetext{
42 Burcuoğlu, Quo Vadis, s.43-44; İnceoğlu, II, s.333; Sanlı, s.108; Hekim, s.68-69.

43 Burcuoğlu'ya göre, aksi yöndeki görüşler, olsa olsa kesinlikle katılmanın mümkün olmadığ contra legem bir temenni anlamını taşır (Quo Vadis, s.50). Hekim'e göre, “(...) TBK m.347/I’in ilk cümlesinde uzama süresi ile ne kast edildiği ortaya konmuştur, ardından da kiraya veren bakımından on yıllık bir uzama süresinin geçmiş olması şartı açıklanmıştır. Kanun koyucunun iradesi bu denkli açık iken on ylllı sürenin hesabına kira süresinin dahil edilmesi, (yazara göre) bu iradenin yok sayılması anlamını taşıyacaktır. Aksi yöndeki görüşler, ancak olması gereken hukuk bakımından tartışma konusu yapılabilir niteliktedir" (s.69).

44 Burcuoğlu, Quo Vadis, s.43.
} 
fikralarında düzenlemez; her iki durum için de aynı hükmü sevk ederdi. Olması gereken hukuk açısından farklı bir görüş savunulabilirse de, yürürlükteki düzenleme açısından kanun koyucunun açık iradesini yok saymak isabetli değildir ${ }^{45}$.

Bu görüşteki yazarlara göre, karşı görüşün ileri sürdüğü, uzun süreli konut ve çatılı işyeri kiralarında on yıllık uzama süresinin, kira süresinin bitiminden itibaren işlemeye başlamasının kabul edilmesi halinde, bu durumun kiraya veren açısından mağduriyete yol açacağı ve toplumsal huzuru bozacağı fikri de isabetli değildir. Çünkü uzun süreli kira sözleşmesi yapmayı tercih etmesi halinde, kiraya veren, bu duruma kendisi yol açmış olur. Bu durumla karşılaşmak istemeyen kiraya veren, sözleşme özgürlüğü içerisinde, daha kısa süreli bir sözleşme yapmayı tercih etmelidir. Böylece sebep göstermeksizin sözleşmeyi feshetme hakkına daha erken kavuşabilir ${ }^{46}$.

On yıllık sürenin, kira süresinin bitiminden itibaren başlayacağının kabul edilmesi halinde kişilik haklarını ihlal edici bir yorum yapılmış olacağı yönündeki görüş ${ }^{47}$ de isabetli değildir. Tarafların ekonomik özgürlüklerini aşırı ölçüde sınırlamamak kaydıyla on yıldan daha uzun süreli kira sözleşmeleri yapılmasının ya da kira sözleşmesinin on yıldan daha uzun sürmesinin kamu düzenine aykırı düşeceği söylenemez ${ }^{48,49}$. Öte yandan, bu görüşün kabul edilmesi halinde, on yıldan daha uzun süreli sözleşmelerde, on yılın bitimiyle sözleşmenin süresinden önce kiraya veren tarafından feshedilebilme imkânının da kabul edilmiş olacağ savunulmuştur ${ }^{50}$.

45 İnceoğlu, II, s.333; aynı yönde Ayanoğlu Moralı, TBK 347, s.114-116; Sanlı, s.109; Karabağ Bulut, s.149; Hekim, s.69.

46 İnceoğlu, II, s.334; Burcuoğlu, Quo Vadis, s.44; Ayanoğlu Moralı, Şerh, N.39; Hekim, s.69-70.

47 Bu görüş için bkz. yukarıda §III.A.1.

48 İnceoğlu, II, s.334. Yazar, bu görüşün yargı uygulamasınca da desteklendiğini belirtmek için, uzama süreleriyle birlikte kırk yıldır devam eden bir kira sözleşmesinin geçerli olduğu yönündeki Y.13HD’nin 04.03.2002, 10836/2023 sayılı kararını örnek olarak göstermektedir. Aynı yönde Karabağ Bulut’a göre, “(...) on yılllk sürenin belirli sürenin sona ermesinden itibaren başlatılmasının toplumsal huzuru bozacağ ve her durumda kamu düzenine aykırı oldukları hususuna katılmak da mümkün değildir. Bir kere yukarıda da ifade edildiği üzere, Türk Borçlar Kanunu belirli sürenin kırk veya elli yıl olmasını yasaklayan bir hüküm sevk etmiş değildir. Ayrıca süresi on yılı aşan belirli süreli kira sözleşmelerinin sırf bu nedenle kişilik hakkını ihlal ettiği veya kamu düzenine aykırı olduğu da söylenemez. Bir sözleşmenin kişilik hakkını ihlal etmesi yalnızca süresi dikkate alınarak tespit edilemez. (...) Burada sözleşmede kararlaştırılan edimlerin, sözleşmenin kiracı veya kiraya verene sağladığı her türlü katkının ve sözleşmedeki bütün somut şartların birlikte değerlendirilerek sonuca varılması gerekmektedir" (s.149). Aynı yönde Demircioğlu, s.192.

İnceoğlu, ayrıca, karşı yöndeki görüşün kabul edilmesi durumunda, taraflarca daha baştan on beş yıllık bir kira sözleşmesi yapılması halinde, bu görüşün doğal sonucu olarak böylesine uzun süreli yapılan kira sözleşmelerinin de toplumsal huzuru bozdukları ve kamu düzenine aykırı oldukları sonucuna varılması gerekeceğini ve bu sebeple geçersizliğe uğramaları sonucuyla karşılaşılacağı yönünde eleştiride bulunmaktadır (II, s.334-335).

49 Ancak bu noktada belirtmek gerekir ki, Zevkliler/Gökyayla, on yıllık sürenin kira süresi bitiminden itibaren başlatılması şeklindeki yorumun kişilik haklarına (TMK m.23/II) aykırı düşeceği şeklindeki görüşlerini ileri sürerken, kira süresinin on yıldan daha uzun süreli (örneğin on beş yıllık) akdedilmesi halinde ne olacağı konusunda açık bir görüş beyan etmiş değillerdir. Ancak öğretide yapılan eleştiriler, yazarların on yıldan daha uzun süreli sözleşmelerin kısmi geçersizliğe uğrayacağını savunduğu temelinden hareket etmektedir.

50 Bu yönde: Kurșat, s.47. Kanımızca, on yıllık süreye kira süresinin de dâhil olduğunun savunulması halinde, örneğin onaltı yıllık bir kira sözleşmesinde, kiraya verenin onuncu yılın sonunda fesih imkânını kullanabileceği sonucunun kabul edilmiş olacağı şeklinde otomatik bir sonuca varmak isabetli olmaz. Pekâlâ, on yıllık süreye kira süresinin de dâhil olduğu görüşü savunulmakla birlikte, örneğin on altı yıllık sözleşme yapılması halinde, on yılın değil; sözleşme süresinin sonunda sözleşmenin feshedilebileceğini savunmak da bu görüş açısından mümkün olabilir. Dolayısıyla on yılın sonunda her durumda fesih hakkının kabul edilmesi gerekeceği ya da on yılı aşan kira sözleşmelerinin kısmi hükümsüz olacağı, bu görüşün otomatik bir sonucuymuş gibi söylenemez. 
Zevkliler/Gökyayla tarafindan savunulan ve görüşlerine dayanak olarak gösterilen, TBK m.347/I,c.3 hükmündeki belirsizliğin, TBK m.328 hükmünün kıyasen uygulanmasıyla çözülebileceği ve TBK m.328 gereğince fesih dönemleri bakımından sözleşmenin başlangıcını esas almış olmasına dair hükmün, TBK m.347/I, c.3 bakımından uygulanarak, on yıllık sürenin kira süresinin başlangıcından itibaren hesaplanacağ yönündeki görüş de karşı yöndeki çoğunluk görüşü tarafindan eleştirilmiştir ${ }^{51}$. Zira TBK m.328 hükmü belirsiz süreli sözleşmelere ilişkin bir hükümdür. TBK m.347/I, c.3 hükmünde, iddia edildiği gibi, bir belirsizlik bulunmadığg 1 için, TBK m.328 hükmünün uygulanmasına gerek olmadığı gibi, bir an için bu hüküm uygulansaydı dahi, ancak belirsiz süreli sözleşmeler bakımından uygulama alanı bulabilirdi. Oysa ki, TBK m.347/II hükmü, zaten belirsiz süreli sözleşmeler bakımından kira süresinin başlangıcını esas almaktadır. Öte yandan TBK m.347/I, c.3 hükmü ile TBK m.347/II hükmü arasında bir çelişki de bulunmamaktadır. Zira belirsiz süreli sözleşmelerde, "sürenin sona ermesi" ya da "uzama süresi" diye bir olgu söz konusu değildir. Bu sebeple de belirsiz süreli sözleşmeleri düzenleyen TBK m.328 hükmünden belirli süreli sözleşmeler için kıyas yoluyla bir çıkarımda bulunmak isabetli değildir.

Demircioğlu'ya göre ${ }^{52}$, "konut ve çatılı işyeri kiralarında sinırlı sayıdaki tahliye sebepleri gerçekleşmedikçe ve kiracı da sözleşmeyi fesih veya ihlal etmedikçe, sözleşmenin süresiz şekilde devamının engellenmesi, tarafların iradeleriyle belirledikleri sözleme süresinin değil, bu iradenin dişında sadece Kanun gereği gerçekleşen uzama süresinin sinırlandırılması ile gerçekleşir. Bu sebeple, "on yıllık süre sınırına”, sözleşmede öngörülen süre dâhil edilmemelidir. Aksi düşünce, örneğin bir yll süreli akdedilen sözleşme kanun gereği tam dokuz yll uzadıktan sonra; dokuz yll süreli akdedilen sözleşme ise kanun gereği sadece bir yll uzadlktan sonra bildirimli fesih hakkının tanınması sonucunu doğurur ki, bu kiraya verenin iradesinin hiçbir şekilde dikkate alınmaması demektir. Oysa ilk ihtimalde kiraya verenin iradesi sözleşmeyle kusa süreli bir bağllllğa yönelmiş iken; ikinci ihtimalde kiraya veren çok daha uzun süreli bir sözleme yapmayı baştan kendisi arzu etmiştir".

Hukukun ekonomik analizine dayanan bir görüşe göre ${ }^{53}$ de, kira ilişkilerinde kiraya verenin firsatçı davranış sorunu ${ }^{54}$ söz konusu olabildiği için, on yıllık uzama süresinin daha kısa olacak şekilde yorumlanması isabetli olmaz.

\footnotetext{
51 İnceoğlu, II, s.334-335.

52 Demircioğlu, s.191 (ancak yazar, kanunda düzenlenen on yıllık uzama süresi bakımından de lege ferenda olarak farklı görüştedir: Bkz. s.193-196. Bu görüş için bkz. yukarıda §II).

53 Sanlı, s. 140.

${ }_{54}$ Bununla kiraya verenin, kiralanan yeri konumu ve koşulları sebebiyle kiralamak zorunda kalan ya da özgürce seçim yapamayan kiracının sömürülmek istenmesi anlatılmak istenmektedir.
} 


\section{Kiraya Veren Tarafından Fesih Bildiriminin Yapılabileceği En} Erken Zaman Dilimi: Fesih Bildiriminin On Yıllık Uzama Süresinin Tamamlandığı Kira Döneminde Mi Yoksa Tamamlanmayı Takip Eden İlk Uzama Yılında Mı İleri Sürülebileceği Hakkındaki Görüssler

Yavuz/Acar/Özen tarafindan savunulan 55 "kiracının on iki yıl korunması (1 kira y1lı + 10 uzama y1l1 +1 takip eden uzama yıl1) sistemine göre, kiraya verenin, -en az üç ay öncesinden bildirimde bulunmak kaydıyla en erken- on yılın sonunda değil; on yılın tamamlanmasını izleyen ilk uzama yılının sonunda kira sözleşmesini feshedebileceği görüşü benimsenmiştir. Ancak kira süresi on iki y1ldan daha uzun ise, kira süresinin sona ermesinden en az üç ay önce yapılacak bildirimle sözleşme sona erdirilebilir.

Sözleşmede öngörülen kira süresinin, on yıllık uzama süresine dâhil olduğunu savunan görüşteki yazarların çoğunluğuna göre ${ }^{56}$, on y1llık süre, sözleşmenin hükümlerini doğurmaya başlaması anından itibaren işlemeye başlayıp, onuncu yılın sonunda sona ereceğine göre, anılan yazarların onuncu yılın bitiminde kiraya verenin sözleşmeyi feshedebileceğini kabul ettikleri sonucuna varılmak gerekir. Sözleşmede öngörülen kira süresinin, on yıllık uzama süresine dâhil olduğunu savunan görüşteki yazarlardan diğer bir $\mathrm{k}_{\mathrm{s} m \mathrm{1}^{57}}$ ise, on yılın bitiminden itibaren takip eden uzama yılının sonunda (on birinci yılın sonunda) sözleşmenin sona ereceği görüşündedirler. Gümüş'e göre ${ }^{58}$, kira süresi on ylldan daha uzun ise, TBK m.347/II hükmü ${ }^{59}$, on yıldan daha uzun süreli konut ve çatılı işyeri kiralarına kıyasen uygulanmalıdır. Buna göre, kiraya veren fesih hakkını en erken sözleşmeyle kararlaştırılan bu sürenin bitiminde ya da sürenin bitimini izleyen kira dönemlerinin sona ermesinden en az üç ay önce yapacağı bildirimle kullanabilir. Diğer bir deyişle, kira başlangıcından itibaren on yılın dolması üzerine kira sözleşmesini sona erdiremez. Örneğin on yedi yıllık bir kira sözleşmesinde, kiraya veren; en az üç ay önceden bildirimde bulunmak koşuluyla- on yedinci y1lın sonunda ya da on yedinci yllın bitimini izleyen her bir yıllık kira döneminin sonunda kira sözleşmesini feshedebilir.

Kira süresinin on yıllık uzama süresine dâhil olmaması gerektiğini savunan hâkim görüşteki yazarların çoğunluğuna göre ${ }^{60}$, on yıllık uzama süresinin sonunda değil;

\footnotetext{
Yavuz/Acar/Özen, s.660.

56 Doğan, Sona Erme, s.63; Zevkliler/Gökyayla, s.344; Aydemir, s.79; Öztürk, s.1555-1556.

57 Gümüss, Kira Sözleşmesi, s.312-313; Gümüş, Özel Hükümler, s.336; Gümüş, Armağan, s.122-123; Remzi/Aydın, s.169.

58 Gümüş, Kira Sözleşmesi, s.313;Gümüş, Armağan, s.122-123; aynı yönde Özdoğan/Oymak, s.532.

59 Gümüş, önceki eserinde (Kira Sözleşmesi, s.313), kıyasen "TBK m.347/I, c.3” hükmünün uygulanacağını belirtmiş ise, de sonraki eserinde bu ifadeyi düzelterek kıyasen uygulanacak maddenin "TBK m.347/II" olduğunu belirtmiştir: Bkz. Armağan, s.123, dn.7.

60 Burcuoğlu, Tasarı, s.36; Burcuoğlu, Seminer, s.67; Burcuoğlu, Quo Vadis, s.39, 43-44, 50; İnceoğlu, II, s.333 vd; Öz, s.75-76; Ayanoğlu Moralı, TBK 347, s.114; Ayanoğlu Moralı, Şerh, N.30, 37-38; Köstekçi, s.72-73; Aydoğdu/ Kahveci, s.642 vd; Karabağ Bulut, s.146; Sanl, s.108-109, 112; Şenyüz, s.353-354; Akgün Akay, s.24; yürürlükteki hukuk açısından bu görüşte N.Yavuz, Değişiklikler, s.554; N.Yavuz, Borçlar Hukuku, s.978; N.Yavuz, Kira Hukuku, s.664 (Yazarın olması gereken hukuk anlamındaki görüşü için bkz. yukarıda dn.28); Hekim, s.68. On yıllık uzama süresinin başlangıç anı hakkında açık bir görüş belirtmemekle birlikte, kiraya verenin fesih hakkını kullanabileceği en erken zaman dilimi açısından bu görüşte: Nevzat Koç, "6098 Sayılı Türk Borçlar Kanununda Kira Sözleşmesine İlişkin Olarak Yapılan
} 
on yıllık süreyi takip eden her bir uzama yılının sonunda, bu tarihten en az üç ay önce fesih bildiriminde bulunulmuş olmak kaydiyla, kira sözleşmesinin kiraya veren tarafından sona erdirilebileceğini kabul ederler. Yargıtay uygulaması da bu yöndedir ${ }^{61}$. Örneğin, kiraya veren, bir yıllık bir kira sözleşmesinde, on ikinci yılın bitiminde önce; beş yıllık bir kira sözleşmesinde ise on altıncı yılın bitiminden önce olağan fesih hakkını kullanamayacaktır.

Buna karş1lık hâkim görüşteki yazarlardan Akyiğit'e göre ${ }^{62}$, TBK m.347/I, c.3 hükmü, kiraya verenin olağan fesih hakkını, en erken onuncu uzama yılının sonunda kullanabileceği yönünde anlaşılmalıdır.

\section{Tarafların Mevcut Kira İlişkisi Devam Ederken Yeni Bir Kira Sözleşmesi Akdetmelerinin Etkisi}

Mevcut bir kira sözleşmesindeki kiraya veren ve kiracı taraf, ilk ihtimal olarak, henüz mevcut sözleşmedeki kira süresi dolmadan önce yeni bir kira sözleşmesi akdetmiş ya da bir tecil anlaşması yapmış olabilirler. İkinci ihtimalde ise, taraflar, mevcut kira sözleşmesindeki on yıllık uzama süresi devam etmekte iken, yeni bir kira sözleşmesi akdetmiş ya da sözleşmeyi tadil ederek yeni bir kira süresi belirlemiş olabilirler ${ }^{63}$.

\section{A. Tarafların, Mevcut Kira Sözleşmesindeki Kira Süresi Dolmadan Önce Yeni Bir Kira Sözleşmesi Akdetmeleri}

Bir kira sözleşmesindeki kira süresi henüz dolmadan ve uzama yıllarına geçilmeden önce, taraflar bir araya gelerek yeni bir kira sözleşmesi akdedebilirler. Bu durumda on yıllık uzama süresinin akıbeti, on yıllık sürenin başlangıcı konusunda öğretide savunulan görüşlere göre ${ }^{64}$ değișecektir.

"Kira süresinin, on yıllık uzama süresinin hesabına dâhil edilmesi gerektiği görüşü”nü savunan yazarlar ile "kiraya verenin toplamda on ikinci yılın sonunda sözleşmeyi sona erdirebileceği görüşü’nü savunan yazarlar, bu konu bakımından açık bir görüş beyan etmemişlerdir.

Yeni Düzenlemelerin Genel Değerlendirmesi”, İstanbul Medipol Üniversitesi Hukuk Fakültesi Dergisi, İstanbul 2014, C.I, S.1, s.27-28; ayrıca bkz. Dokuz Eylül Üniversitesi Hukuk Fakültesi Dergisi, Prof. Dr. Şeref ERTAŞ’a Armağan, C.

19, Özel Sayı-2017, s.97-98. Ayrıca bkz. Ceran, BK Sempozyumu, s.150; Ceran, HMK-BK Sempozyumu, s.237, 244; Demircioğlu, s.191, 194-195.

On yıllık sürenin başlangıç anı konusunda görüş beyan etmemekle birlikte, on yıllık uzama süresinin dolmasını takip eden uzama yılının sonundan itibaren sözleșmenin sona erdirilebileceği görüşünde: Arpacı, s.91; Erzan Erzurumluoğlu, Sözleşmeler Hukuku (Özel Borç İlişkileri), 7.Bask1, Yetkin, Ankara 2017, s.121.

61 Bkz. yukarıda dn.42'de anılan kararlar.

62 Akyiğit, s.169.

63 Ekleyelim ki, sözleşmenin devri veya kiralananın kullanım hakkının devrine ilişkin sözleşmeler, kural olarak, mevcut kira sözleşmesinin kira süresine ya da on y1llık uzama süresine etki etmezler.

${ }^{64}$ Bu görüşler için bkz. §III. Ayrıca bkz ve karş. Faruk Acar, "Belirli Süreli Konut ve Çatılı İşyeri Kira Sözleşmelerinin Yenilenmesi Halinde Kiraya Verenin On Y1llık Sürenin Bitmesi Sebebiyle Bildirim Yoluyla Sözleşmeyi Sona Erdirmesi”, Yargıtay Uygulaması Çerçevesinde Borçlar Hukuku ve Eşya Hukukundaki Güncel Gelişmeler Ulusal Sempozyumu, Bildiri Özetleri, 2 Kasım 2018, Yeditepe Üniversitesi, İstanbul 2018, s.10. 
Öğretide hâkim görüş olan "kira süresinin, on yıllık uzama süresinin hesabına dâhil edilmemesi gerektiği görüşü”, meseleyi kira süresinin uzatılması yönünden ele almıştır ${ }^{65}$. Inceoğglu'ya göre, mevcut kira sözleşmesi devam ederken, taraflar yeni bir kira sözleşmesi akdederek yeni bir kira süresi kararlaştırırlarsa, bundan hukuken anlaşılması gereken, mevcut kira sözleşmesindeki kira süresinin uzatıldığı ve yapılan yeni anlaşmanın bir tecil anlaşması mahiyetinde olduğudur ${ }^{66}$. Bu görüşe göre, on yıllık uzama süresi, ancak bu kararlaştırılan yeni kira süresinin bitiminden itibaren işlemeye başlayacaktır ${ }^{67}$.

\section{B. Tarafların, Mevcut Kira Sözleşmesindeki On Yıllık Uzama Süresi Devam Etmekte İken, Yeni Bir Kira Sözleşmesi Akdetmeleri}

Mevcut kira sözleşmesinin on yıllık uzama süresi devam ederken, kiraya veren ve kiracının bir araya gelerek yeni bir kira sözleşmesi akdetmek suretiyle ya da mevcut sözleşmeyi tadil ederek yeni bir kira süresi belirlemiş olmalarının, mevcut kira sözleşmesindeki on yıllık uzama süresine etkisinin ne olacağı tartışmalıdır.

Tartışmaya geçmeden önce belirtmek gerekir ki, kira sözleşmesinin taraflarının yenileme (TBK m.133) yoluyla değişmesi halinde, hiç tereddütsüz ortada yeni bir sözleşme söz konusu olacağından aksi kararlaştırılmadıkça, on yıllık uzama süresi yeni sözleşmeye göre belirlenir. Ancak kira sözleşmesinin devri sebebiyle ya da kiralananın el değiştirmesi sebebiyle bir taraf değişikliği söz konusu ise, aksi kararlaştırılmadıkça, mevcut kira sözleşmesi devam eder ve on yıllık uzama süresi mevcut kira sözleşmesine göre hesaplanır ${ }^{68}$.

Acar'a göre, “(...) yenileme sözleşmesinin varlı̆̆ halinde on ylllk sürenin yeniden başlatılması kabul edilmelidir. Ancak bu kabulün mutlak olarak uygulanması da haksızlk yaratabilmektedir. Sözleşme koşullarında değişiklik yapma niyetinin bulunmadı̆̆ özellikle süreyi uzatma düşüncesi olmakszzın, ispat aracı oluşturmak üzere yenileme sözleşmesinin yapllması durumları teyit mektubunda olduğu gibi işlev görmekte olduğu gözden trak tutulmamalddrr. Bu tip sözleşmeleri eskiyi yürürlükten kaldıran yerine yenisini ikame eden (gerçek bir) yenileme sözleşmesi saymamak gerekir. Konut ve çattll işyeri kiralarında Kanun gereği sözleşmenin zaten yenilendiği (kiraya verenin sözleşmeyi bildirim yoluyla fesih imkanının olmadığı) bir düzende, kiraya verenin sözleşmeye devam etmeme özgürlüğünün olmadı̆̆g dikkate alınırsa, eski sözleşmeyle bütünüyle aynı koşullarda yapılan yenileme sözleşmesini sözleşme özgürlüğ̈unün tam uygulandığı diğer sözleşmelere ilişkin yenileme sözleşmeler(i) gibi kabul etmemek, kira sözleşmesi özelinde eski sözleşme gibi kabul etmek daha isabetli saylabilir. Bu ihtimalde, TBK m.347'deki on ylllk süreyi ilk sözleşmenin başlangıç tarihinden itibaren başlatmak gerekir" ${ }^{\prime 69}$.

\footnotetext{
Siz aşağıda konuyu sadece tecil anlaşması yönünden değil; mevcut kira sözleşmesinin bedele ilişkin veya başkaca bazı hükümlerinin değiştirilmesi yönünden ayrı ayrı ele almaktayız: Bkz.§VII.B.1.d.

66 İnceoğlu, II, s.336.

${ }_{67}$ Bu görüşte: İnceoğlu, II, s.336; Sever, s.209; Akgün Akay, s.25.

68 Karş. İnceoğlu, II, s.335-336.

69 Acar, s.10.
} 
Öğretide hâkim görüş olan "kira süresinin, on yıllık uzama süresinin hesabına dâhil edilmemesi gerektiği görüşü"nü savunan bazı yazarlar arasında bu konuda bir görüş birliği yoktur. Birinci görüşe göre ${ }^{70}$, kiralanan ya da kiracı değişmediği sürece, yeni kira sözleşmesinin, aslında eski kira sözleşmesinin devamı niteliğinde olduğu kabul edilmeli ve on y1llık uzama süresi, ilk kira sözleşmesinin süresinin tamamlandığı andan itibaren başlatılmalıdır ${ }^{71}$. Bu görüş kabul edilecek olursa, bu görüşün tutarlı bir sonucu olarak, kanımızca, eğer yeni kararlaştırılan kira süresi, mevcut sözleşmedeki on yıllık uzama süresini aşıyorsa, on yıllık uzama süresinin sonunda değil; yeni kararlaştırılan sürenin sonunda, kiraya verenin sözleşmeyi fesih hakkına sahip olacağı kabul edilmek gerekir.

İkinci bir görüş̧ ${ }^{72}$, taraf iradelerinin yorumuna öncelik verilmesi gerektiğini, önceki kira sözleşmesinin taraflarında herhangi bir değişiklik olmasa bile yeni bir kira sözleşmesinin kurulmuş olduğunun karine olarak kabul edilmesi gerektiğini savunur. Hatta, sadece kira bedelini belirlemek için yeni bir kira sözleşmesi akdedilmiş olsa bile on yıllık uzama süresi, bu yeni sözleşmenin süresinin tamamlanmasından itibaren başlamalıdır ${ }^{73}$.

Üçüncü bir görüsse göre ${ }^{74}$, taraflar on y1llık uzama süresi dolmadan önce yeni bir kira sözleşmesi akdetmiş iseler, bu yeni sözleşmedeki sürenin sona ermesinden itibaren on yıllık uzama süresinin başlaması gerekir. Çünkü kanun koyucu TBK m.347/I, c.3 hükmünde kira sözleşmesine bir "üst süre" getirmiş değildir; aksine uzama süresine bir sınırlama getirmiştir. Ayrıca kanun koyucu tarafların sözleşmeyi en fazla on yıl uzatabileceğine dair de bir hüküm sevk etmiş değildir. TBK m.347 hükmünün, kiracıyı koruma amacına uygun olarak yorumlanması gerekir ki, bu yorum da yeni sözleşme süresinin bitiminden itibaren on yıllık uzama süresinin başlaması gerektiği sonucuna varmayı gerekli kılar. Kiraya veren uzama süresi devam ederken, yeni bir kira sözleşmesi yapmayı kabul ediyorsa, bunu kendi özgür iradesi ile gerçekleştirmektedir. Bununla birlikte, şayet taraflar yalnızca kira bedelini belirlemek amacıyla yeni bir kira sözleşmesi akdetmiş ve diğer sözleşme hükümlerinde herhangi bir değişiklik söz konusu değil ise, yeni kira sözleşmesinin, on yıllık uzama süresi içerisinde kalacağı kabul edilebilir.

Dördüncü bir görüşe göre ${ }^{75}$, on yıllık uzama süresi tamamlanmadan, tarafların yeni bir kira sözleşmesi akdetmeleri halinde, tarafların iradelerine bakılarak yorum

\footnotetext{
70 İnceoğlu, II, s.336; Akgün Akay, s.25.

71 İnceoğlu'ya göre, “(...) önemli olan yeni kira sözleşmesinin eskisinin devamı niteliğinde olup olmadığının tespitidir. / Özellikle kiracı değiştiği için kiracı ile yeni bir kira sözleşmesi yapılmış veya kiralanan değişmişse artık on yıllık süre bu ikinci sözleşmenin süresinin sona ermesinden itibaren başlamalıdır" (II, s.335).

72 Sanlı, s. 113 ve orada dn. 30 .

73 Sanlı, s.113, dn.31.

74 Kurşat, s.48-51, 52.

75 Hekim, s.74-75.
} 
yapılması gerekir. Buna göre, yeni sözleşme, bir "yenileme sözleşmesi” (novatio) (TBK m.133) ${ }^{76}$ olarak yorumlanabiliyorsa, on yıllık uzama süresi yeniden işlemeye başlamalıdır. Buna göre, on yıllık uzama süresi, yeni kira süresinin tamlamamasından itibaren işlemeye başlayacaktır. Bu görüşe göre sürekli borç ilişkileri bakımından, yenileme, mevcut sözleşmenin aynı şartlarda belirli bir süre daha devam etmesi için yapılmaktadır ve mevcut sözleşmenin süre dişındaki şartlarında değişiklik yapılmaması, yenileme bulunmadığı anlamına gelmez. Buna karşılık tarafların iradesi, yenileme değil de mevcut sözleşmenin süresinin uzatılması yönünde ise, bu kere on yıllık uzama süresi yeniden işlemeye başlamaz.

Yargıtay, devam etmekte olan kira sözleşmesindeki on y1llık uzama süresi içerisinde tarafların yeniden kira sözleşmesi akdetmeleri durumunda, on yıllık uzama süresinin yeni akdedilen kira sözleşmesinde belirlenen kira süresinin dolmasından itibaren başlayacağını kabul etmektedir ${ }^{77}$.

\section{Kiraya Verenin TBK m.347/I, c.3 Hükmüne Dayanan Bildirim Yoluyla Fesih Hakkının Sınırlanıp Sınırlanamayacağı}

Gümüş, yürürlükteki hukuk açısından, TBK m.347/I, c.3 hükmünün dürüstlük kuralı ile sinırlanabileceğini ileri sürmektedir ${ }^{78}$. Buna göre, kiraya verenin TBK m.347/I, c.3 gereğince fesih hakkını kullanması ile elde edeceği menfaat ile kiracının sözleşmenin sona ermesi üzerine uğrayacağı zarar arasında aşırı bir oransızlık söz konusu olacaksa, kiraya verenin, kira sözleşmesini feshetmesi suretiyle hakkını kötüye kullandığg (TMK m.2/II) kabul edilmelidir.

${ }_{76}$ Yenileme (novatio), hem dar anlamdaki (borçlar), hem de geniş anlamdaki borç ilişkileri (sözleşmeler) için söz konusu olabilir.

77 Y.6HD 22.2.2016,9211/1178: "Taraflar arasında 1996yllında başlayan kira ilişsisi konusunda uyuşmazlık bulunmamaktadır 1.4.1996 başlangıç tarihli 1 yll süreli ilk sözleșmeden sonra, 2.sözleşme 1.8.1996 başlangıç tarihli 1 yll süreli, 3. sözleșme 1.4.1999 başlangıç tarihli 1 yll süreli, 4. sözleşme 1.1.2002 başlangıç tarihli 1 yll süreli, 5. sözleşme 1.1.2008 başlangıç tarihli 1 yıl süreli, 6. sözleşme 1.1.2009 başlangıç tarihli 1 yıl süreli, 7.sözleşme 1.1.2010 başlangıç tarihli 1 yll süreli, 8 . sözleşme 1.1.2011 başlangıç tarihli 1 yll süreli, 9. sözleşme 1.1.2013 başlangıç tarihli 1 yıl süreli sözleşmeler imzalanmış, son olarak da 1.1.2014 başlangıç tarihli 1 yıl süreli sözleșmeyle kira ilişskisinin yenilendiği anlaşılmış̦tır. Bu durumda taraflar arasında geçerli olan sözleşmenin en son akdedilen 1.1.2014 başlangıç tarihli kira sözleşmesi olduğunun kabulü gerekir. Bu durumda davacının on yıllık uzama süresinin dolduğundan bahisle dava açma hakkı kalmamışıtı. Davacı ancak TBK.nunda belirtilen tahliye sebeplerinden birine dayanarak sözleşme sonunda dava açabilir. Mahkemece 1.1.2014 bașlangıç tarihli kira sözleșmesi esas alınarak davanın reddine karar verilmesi gerekirken, yazıl gerekçeyle 1.4.1996 başlangıç tarihli kira sözleșmesine istinaden davanın kabulüne karar verilmesi doğru değildir” (Kazancı İBB). Aynı yönde Y.6HD 02.11.2015, 6677/9299 (Kazancı İBB): "Kiralanan TBK.nun konut ve çatılı işyeri kirası hükümlerine tabi olup, taraflar arasında düzenlenen 01.10.1997 başlangıç tarihli ve 5 yıl süreli kira sözleşmesi 01.09.2003 başlangıç tarihli ve 10 yll süreli sözleşme ile yenilenmiştir. Bu husus dosyaya sunulan ve tarafların kabul ettiği yazll kira sözleşmelerinden anlaşılmaktadır. Bu durumda taraflar arasında geçerli olan sözleşmenin son sözleşme olan 01.09.2003 başlangıç tarihli ve 10 yll süreli kira sözleşmesi olduğunun kabulü gerekir".

Y.3HD 14.02.2017, 1527/1292 (Legalbank): "Davacının dayandığ 01/07/1998 başlangıç tarihli ve bir yıl süreli kira sözleșmesinden sonra düzenlenen ve uyușmazlık konusu olmayan 01/01/2008 bașlanglç tarihli ve bir yıl süreli kira sözleşmesi ile taraflar arasındaki kiracılık ilişsisi yenilenmiştir. Bu durumda kiralanan TBK.nun konut ve çatılı işyeri kirası hükümlerine tabi olup, taraflar arasında imzalanan 01/01/2008 başlangıç tarihli bir yıl süreli kira sözleşmesine değer verilerek kira sözleşmesinin 01/01/2009 tarihinden itibaren kiracı tarafindan sürenin bitiminden en az onbeş gün önce bildirimde bulunulmadıkça TBK.nun 347. maddesi uyarınca aynı koşullarla yıldan yıla yenilenerek ve bu şekildeki uzama süresinin on yıla ulaşması gerektiği kabul edilmelidir".

Kararlarda "yenileme" terimi kullanılmıssa da, bununla, kanımızca TBK m.133 anlamındaki yenileme (novatio) kurumu kastedilmemektedir. Nitekim kararda geçen "aynı koşullarda yıldan yıla yenilenerek" ifadesi de kast edilenin, "kanundan doğan uzama" olduğu izlenimini uyandırmaktadır.

78 Gümüș, Armağan, s.139 vd. 
"Bu çerçevede ister konut ister işyeri kirası olsun müşteri çevresini kaybetme tehlikesi içindeki işyeri kiracısı veya aynı muhitte aynı nitelikte kiralanan bulamama durumunda olan konut kiracısı, kiraya veren bildirim hakkını kullanmadan önce, kiraya verenin üçüncü kişilere kiraya vermek istediği kiralanana ilişkin olarak kiraya verenle kira bedeli, süresi vs sözleşme şartları bakımından kiraya verenin sübjektif iradesine uygun olan şartlarda yeni bir kira sözleşmesi akdetmek istediğini bildirirse ve buna rağmen kiraya veren bildirim hakkını kullanırsa, söz konusu hakkın kullanımı TMK m.2/II gereği bir hakkın kötüye kullanımı hali olarak hüküm ve sonuç doğurmaz. Aynı sonuç kiracının talebini bildirimin kendisine varma anı ile sona erme tarihi arasında kiraya verene ilettiği halde de geçerlidir. Bildirim sonrası uzama yılının sonunda yine dürüstlük kuralı gereği (TMK m.2/I) kiracı ve kiraya veren arasında yeni bir kira sözleşmesi, kiraya verenin sübjektif iradesi üzerinden kendiliğinden kurulur. Bu kapsamda kira bedeli bakımından kiraya verenin sübjektif irade beyanına uymadiğl sürece, kiracının uygun kira bedeli veya rayiç kira bedeli ödeme teklifi yeterli değildir, kiraya verenin kira bedeli talebi tam olarak karşılanmalıdır ${ }^{79}$. (...) Fesih bildirimi sonrası kurulan sözleşme yeni bir sözleşme olduğundan TBK m.347/I, c.3'teki süreler yeniden işlemeye başlar, zira kiraya verenin üçüncü kişi ile akdedeceği sözleşme yine yeni bir sözleşme olacaktı. Gabin (aşırı yararlanma) hükmünün (TBK m.28) iş bu duruma uygulanabilmesi kanımızca mümkün değildir" ${ }^{\prime \prime 0}$.

Kanaatimizce, kiraya verenin TBK m.347/I, c.3 gereğince fesih hakkını kullanmas1, kanun koyucunun sözleşmeyle bağll1ıktan kurtulmak ve kiralananın zilyetliğini yeniden elde etmek için ona tanıdı̆̆ bir sebep göstermeye" dahi gerek kalmaksızın sadece kanunda öngörülen sürenin dolmuş olması üzerine tanınmıştır. Bu hakkın verilme sebebi ise, kiraya verenlerin mülkiyet hakkının aşırı ölçüde sınırlandırılmasının önüne geçmek düşüncesidir. Diğer bir deyişle, bizatihi kanunda bu hakkın tanınması ile amaçlanan (ratio legis), kiraya verenin -mülga kanun döneminde olduğu üzere- ölümle bile bitmek bilmeyen süresiz bir sözleşmenin zincirlerinden kurtulmasını sağlamaktır. O halde, kanunun ihdas ettiği söz konusu fesih hakkı ile kiraya verene tanıdığı sözleşmesel bağl1lıktan kurtulma hakkının bizatihi kendisi hakkın kötüye kullanılmasına kaynak oluşturamaz. Kiraya veren, kiralananı yeniden kiralamak amacını taşısa bile ve hatta mevcut kirac1, kiraya verenin sübjektif iradesine uygun bir kira bedeli ödeyeceğini taahhüt etse dahi, sözleşme özgürlüğü ilkesi içerisinde, kiraya verenin, sözleşmenin karşı tarafını seçme özgürlüğü vardır. Burada dürüstlük kuralı uygulaması yoluyla, kanunun öngördüğü amacın tam tersini sağlayacak bir şekilde, kiraya verene mevcut kiracıya yeniden öneride bulunma yükümlülüğü ya da mevcut kiracının önerisini kabul etme yükümlülüğü; ezcümle sözleşme yapma zorunluluğu getirilemez. Kaldı ki, kiraya veren, üçüncü kişinin ödeyeceği kira bedelini ödeyeceğini taahhüt eden mevcut kiracı ile sözleşmeye devam etmek istemiyorsa, bunun psikolojik ya da sosyal; insan ilişkilerine dayanan sebepleri olabilir. Öte yandan müşteri çevresi ve kiralanana

\footnotetext{
79 Yazara göre, “ (...) kiraya verenin üçüncü kişiye kiraya vermek için belirlediği kira bedeli bakımından uyuşmazlık söz konusu ise açılacak teknik anlamda tespit davası ile kira bedeli (ve hatta süresi) kiraya verenin sübjektif iradesi üzerinden hâkim tarafindan belirlenebilir": Gümüş, Armağan, s.140.

${ }^{80}$ Gümüş, Armağan, s.140.
} 
yaptığı yatırımlar sebebiyle olası bir zarara uğramak ve söz konusu iş çevresinde kiralanabilir bir işyeri bulamama riskiyle karşılaşmak istemeyen -üstelik de çoğu kere basiretli tacir olan ya da işinin ehli bir esnaf olan- kiracı, ilk defa sözleşme yaparken, mevcut kira sözleşmesinin süresini hesaba katmalı, gerekirse daha uzun süreli kira sözleşmesi yapmayı tercih etmeli ${ }^{81}$ ve kiraya veren, eğer, uzun süreli bir sözleşme yapmaya yanaşmıyorsa, söz konusu tacir ya da esnaf bu yeri kiralamaktan vazgeçerek, müşteri çevresini oluşturmak ve yatırım yapmak için, serbest piyasa ekonomisi içerisinde, uygun başka bir yer bulmalıdır ${ }^{82}$. Kiraya verenlerin, işyeri kiracılarının müşteri çevresini gözetme ve yatırımlarını boşa çıkarmama gibi bir yükümlülüğü bulunmamaktadır. Böyle yükümlülükler için kiraya verenin ayrıca taahhüt altına girmesi gerekir. Diğer taraftan, bulunduğu muhitten başka muhite taşınmak istemeyen konut kiracısının bu menfaatinin de hukuken korunması elzem olan bir tarafı bulunmamaktadır. Kiraya verenin, kiracısının, aynı muhitte oturmasını sağlama gibi bir yükümlülüğü söz konusu değildir. Aynı muhitten ayrılmak istemeyen kiracı, bu muhitte başka bir kiralık konut araştırmak, imkânı varsa bir konut satın almak, eğer bunları sağlayamıyorsa, başka bir muhitte yaşamına devam etmek zorundadır. Hayat koşulları içerisinde, herkesin her istediğini elde etmesi mümkün olmayabilir. Konut kiracısının aynı muhitten ayrılmama isteğini gerçekleştirmek için, dürüstlük kuralı zorlamasıyla kiraya verene sözleşme yapma zorunluluğu getirilmesi gibi bir sonuç, kanımızca, hukuken korunamaz ve TBK m.347/I, c.3 hükmünün ratio legis'i ile de bağdaşmaz.

81 Sanlı, çatılı işyeri kiracısının, çoğu kere, daha en başından uzun süreli kira sözleşmesi yapmayı tercih etmesini beklemenin gerçekçi bir yaklaşım olmadığını belirtir. Zira, işyeri kiracısının, söz konusu yerde yapacağı ticari faaliyet sonucunda gelir elde edip edemeyeceği, başarılı olup olamayacağı belirsizdir. O nedenle işyeri kiracısından uzun süreli sözleşmeler kurmasını beklemek haklı olmaz (s.131).

Kanımızca, yeni bir iş kuran ve geleceğin ne getireceğinden emin olamayan bir tacir ya da esnafın, bu sebeple uzun süreli bir kira sözleşmesi yapmak istememesi, kendi ekonomik öngörüsüne dayanan tercihidir. Ekonomik geleceği belirsiz olduğu için kısa süreli kira sözleşmesi kuran tacir/esnaf kiracının, başarılı olması halinde, kiraya veren malikin mülkiyet hakkının bu sebeple sınırlanmasının ve fesih hakkının kiracı lehine yoruma tabi tutularak sınılandırılmasının bir gereklilik olduğu kolaylıkla söylenemez.

82 Hukukun ekonomik analizi açısından farklı bir bakıș için bkz. Sanlı, s. 121 vd. Yazar, kiralananın konumunun ve koșullarının kiracı için vazgeçilmez öneme sahip olduğu hallerde ve özellikle çatılı işyeri kiracısının zaman içerisinde oluşturduğu müşteri çevresi nedeniyle kiralananın onun için vazgeçilmez bir değere eriştiği hallerde; kiraya verenin "firsatçı davranış" sergileyerek, kiracıyı sömürme iktidarına kavuştuğunu, on yıllık uzama süresi sonundaki fesih gücünün, kiralanandan çıkmak istemeyen kiracıyı, kiraya verenin istediği yüksek bedel üzerinden sözleşme yapmaya zorladığını belirtmektedir. Böylece kiraya veren, kiracının yarattığı değere ortak olmak istemektedir. Bu sebeple kiraya verenin fesih yetkisinin kısıtlanması, kiracıya yarattığı değeri muhafaza etme imkanı verir ve onu yatırım yapmaya teşvik eder.

Kuşkusuz, yukarıda belirtilen durumlarda, aşırı yararlanma (TBK m.28) koşulları gerçekleşmişse, sözleşmenin uyarlanması ya da iptali mümkündür. Ancak, kiraya verenin rayiç kira bedeli üzerinden sözleşme akdetmek istemesi olağan bir durum olduğu gibi, kiraya verenin aynı kiracı ile psikolojik ya da insan ilişkileri çerçevesinde sözleşme ilişkisine devam etmeme özgürlüğü de kiraya verene tanınmalıdır. Çatılı işyeri kiracısı, kira sözleşmesi yaparken, yapacağı yatırımları da göz önüne alarak bir kira süresi bağıtlamalıdır. Kiraya verenin mülkiyet hakkının, kiracının makro ekonomiye kattığı değer (işyerinin müşteri çevresi kazanması, kiralanan yerin marka değerine ulaşması vs) dikkate alınmak suretiyle sınırlanmak istenmesi de tam olarak hukuksal bir zemine oturmamaktadır. Kiraya verenin, kiracının müşteri çevresi sebebiyle ekonomik olarak zarar etmesini engelleme gibi bir hukuki yükümlülüğ̈̈ yoktur. Özellikle basiretli tacir olan ya da işinin ehli bir esnaf olan kişilerin, çatılı işyeri kiralamalarında, tüm ekonomik sonuçları öngörerek hareket etmeleri beklenir. Öte yandan, her çatılı işyeri kirası için, kiralananın müşteri çevresi açısından vazgeçilmez hale gelmesi söz konusu olmayabilir. Kiralananın değer artışı, bulunduğu muhit ve bu muhitteki sosyal ve ticari yaşamın gelişimiyle sıkı ilintilidir; değer artışında salt kiracının ticari faaliyetinin etkili olduğu, çoğu kere, söylenemez. 


\section{Değerlendirme ve Sonuç}

\section{A. Öğretideki Görüşlerin ve Yargıtay Uygulamasının Değerlendirilmesi}

Kanımızca, TBK m.347/I, c.3 hükmünün açık lafzı karşısında, belirli süreli kira sözleşmeleri bakımından, kanunda geçen "uzama süresi" ifadesinin, kira süresinin sona ermesini müteakiben işleyecek olan kira yılları şeklinde yorumlanması dışında bir "yorum" tarzı mümkün gözükmemektedir. Dolayısıyla hükmün düz ve zıt anlamına göre yapılacak lafzi yorum yöntemiyle Zevkiler/Gökyayla tarafından savunulan on yıllık süreye kira süresinin de dâhil olduğu sonucuna ${ }^{83}$ ulaşılması mümkün gözükmemektedir. Kanun koyucu, hükmün açık lafzına göre belirli süreli sözleşmelerde on yıllık süreyi, kira süresinin bitiminden itibaren başlatmaktan yana bir tercihte bulunurken; belirsiz süreli sözleşmelerde, on yıllık süreyi kira başlangıcından itibaren başlatmaktadır. Kanun koyucunun bilinçli olarak belirli süreli -belirsiz süreli sözleşme ayrımı yapmış olması karşısında, "daraltıcı yorum" yoluyla da bu sonuca varılması mümkün gözükmemektedir. Söz konusu ayrım, açık olup, maddede belirsizlik de söz konusu olmadığı için belirsiz süreli sözleşmelerdeki fesih dönemlerini düzenleyen TBK m.328 hükmünün, belirli süreli kira sözleşmeleri bakımından kıyasen uygulanma imkânı da bulunmamaktadır.

Yavuz/Acar/Özen tarafindan savunulan görüş̧ ${ }^{84}$ göre, kiraya veren tarafından, en erken toplamda on ikinci yılın sonunda (kira süresinin birinci kira y1lı +10 uzama yılı +1 uzama yılı sonunda) kira sözleşmesinin feshedilebileceği sonucuna varmak da, yine hükmün lafzi yorumu ve amaca bağlı yorumu uyarınca mümkün gözükmemektedir. Zira maddenin lafzına bakıldığında, TBK m.347/I, c.3'te geçen "uzama süresi" ifadesinin, aslında TBK m.347/I, c.1'de geçen "bir yıl için uzatılmış sayılır" ifadesi ile bağlantılı olduğu açıktır. Maddede geçen "uzama süresi" ifadesiyle amaçlanan, birer y1l halinde uzayan ve kira süresinin bitiminden itibaren başlayan süreleri ifade etmektir. Diğer bir deyişle, kanun koyucu, "uzama süresi”" ifadesiyle kira süresinin bitmesi üzerine başlayan ve kanundan doğan bir zaman dilimini kast etmiştir. Dolayısıyla, kira süresinin ilk kira yılının bitiminden itibaren işleyecek süreleri de "uzama süresi" olarak nitelemek ve yorumlamak (örneğin 5 y1llık bir kira sözleşmesinde, birinci kira yılının bitimini takip eden 4 kira yılının da on yıllık uzama süresine dâhil edilmesi ve sonra kanuni uzama süreleri olan sürelerden 6 yıl daha ilave edilerek on yıla varılması şeklinde bir yorum yapmak); "yorum yöntemleri uyarınca" pek mümkün gözükmemektedir.

Öğretide çoğunluk tarafından savunulan ve on yıllık uzama süresinin, kira süresinin bitiminden itibaren başlayacağg görüşü ${ }^{85}$, hükmün lafzına uygun düşen bir

\footnotetext{
Bkz. yukarıda §III.A.1

${ }^{84}$ Bkz. yukarıda §III.A.2.

85 Bkz. yukarıda §III.B.
} 
görüştür. Bu görüş kabul edilecek olursa, örneğin on y1l süreli olarak akdedilen bir kira sözleşmesinin, (10 yıllık kira süresi + on uzama yılı + 1 uzama yılı olmak üzere) toplamda en erken yirmi birinci yılın sonunda feshedilebileceği sonucuna varılır. Hatta aynı yöndeki Yargıtay uygulamasına göre ${ }^{86}$, eğer kira sözleşmesinde taraflarca kararlaştırılmış olan kira süresi tecil anlaşmaları yoluyla uzatılırsa, bu yeni belirlenen süreler, on yıllık uzama süresinin kapsamına girmez; ayrıca hesaba ilave olur.

Ancak hükmün ister lafzen isterse amaca göre yorumlanması suretiyle varılsın, hâkim görüşün ve Yargıtay uygulamasının vardığı bu sonuç, kanımızca, adalete aykırı yönler taşıyabilmektedir. Şöyle ki,

İlk olarak, kira süresi tarafların kendi özgür iradeleri ile belirledikleri bir zaman dilimi olmasına rağmen; on yıllık uzama süresi kanundan doğar. $\mathrm{O}$ halde kanuni bir süre olan on y1llk sürenin amacının (ratio legis'in) ortaya konulması gerekir. Kanun koyucu, önceki mülga kanun döneminde kira sözleşmelerinin kiraya veren tarafından, süre gerekçe gösterilerek sona erdirilememesini, mülkiyet hakkının ölçülü olmayan sınırlandırılması olarak görmüş ve bu durumu engellemek amacıyla TBK m.347 hükmünü ihdas etmiştir. Ancak, hükmü düzenlerken, kiracıyı koruma düşüncesini de büsbütün dışlamamış, kiraya verene kira süresinin hemen sonunda bir fesih hakkı tanımayıp, on yıllık uzama süresi sonunda bu imkânı tanıyarak, her iki tarafın menfaatleri arasında bir denge kurmak istemiştir. $\mathrm{O}$ halde, tarafların uzun süreli kira sözleşmesi akdetmeleri halinde, on yıllık uzama süresinin, mülkiyet hakkının ölçülü sınırlanması gerekliliğini ve kiraya veren ile kiracının menfaatleri arasında kurulan kanuni dengeyi zedelemeyecek şekilde uygulanması gerekir. Hâkim görüş tarafından ileri sürülen, tarafların kira sözleşmesi ile bağlılık süresini kısa tutmak niyetinde olmaları halinde kira süresini daha kısa olarak düzenleyebilecekleri yönündeki gerekçe, tarafların uzun süreli kira sözleşmeleri yapmaları halinde bunun sonuçlarına katlanmaları gerektiği sonucunu beraberinde getirir. Oysa kanun koyucu, uzama süresini on yıl ile sınırlandırırken, mülkiyet hakkının sınırlanmasına bir sınır getirmektedir ki, kira süresinin uzun süreli olarak kararlaştırıldığ 1 hallerde bu amaç gerçekleşmemiş olmakta, kiraya veren ile kiracı arasında kurulmaya çalışılan kanuni denge, kiraya veren aleyhine bozulmaktadır.

Tarafların sözleşme özgürlüğü içerisinde kira süresini diledikleri kadar bir zaman süreci olarak belirleyebilmeleri serbestisi, kanun tarafindan on yıllık uzama süresi ile getirilmek istenen amaç ve kurulmak istenen denge ile uyumlu olarak uygulanmak gerekir. Bu bağlamda, kira süresi ve on yıllık uzama süresinin ayrı ayrı değerlendirilerek, kanunun, yalnızca on yıllık uzama süresini düzenlediğini ve bu sebeple kira süresi ne kadar uzun olursa olsun bunun ayrı bir konu olduğunu söylemek isabetli olmaz. Çünkü sonuç itibariyle, kira sözleşmesi ile bağlılık, kira

${ }_{86}$ Bkz. yukarıda §V.B, dn.77. 
süresinin ve uzama süresinin toplamı kadar bir zaman süreci ile bağlılıktır. Şu halde kira süresinin uzun olması, ister istemez, on y1llık kanundan doğan uzama süresinin uygulanma alanını doğrudan ilgilendirmektedir. O halde bunları birbirinden ayrı iki farklı hukuki kurummuş gibi değerlendirmek, kanunun mülkiyet hakkının sınırlanmasına sınır getirme ve tarafların çatışan menfaatleri arasında denge kurma amacı bakımından, adalet duygusunu tatmin eden bir yaklaşım olamamaktadır. Daha açık deyişle, hakim görüş doğrultusunda uzun süreli kira sözleşmelerinde kira süresine on yıllık uzama süresinin de ilave edileceğini kabul etmek, kanunun uzama süresini on yıl ile sınırlama ile güttüğü amacın gerçekleşmesini,-deyim yerindeyse- sulandırmakta ve sözleşme özgürlüğü çerçevesinde istenildiği kadar uzun kararlaştırılabilecek bir kira süresi ile taraf menfaatleri arasında kanun koyucu tarafından kurulduğu varsayılan denge zedelenmektedir. $\mathrm{Bu}$ sebeple, sözleşme özgürlüğü gerekçesiyle kira süresinin serbestçe düzenlenebilmekte olması, on yıllık uzama süresinin uygulanma alanını doğrudan ilgilendirdiği için, on yıllık uzama süresinin hesaplanmasında, kira süresi ve uzama süresi birbirinden bağımsız kabul edilip matematik bir işlem ile toplanmamalı, her iki sürenin bütün bir zaman sürecinin unsurları olduğu dikkate alınmalı; kanun koyucunun amacının gerçekleşmesinin, bu bütün süre bakımından yapılacak bir değerlendirmeyi zorunlu kılacağı, gözden uzak tutulmamalıdır.

İkinci olarak, kanımızca, kanun koyucunun TBK m.347/I, c.3 hükmünü ihdas ederken, uygulamada çoğu kere konut kirası sözleşmelerinin bir yıllık olarak yapılmasından esinlendiği ve böylece aslında bir yıllık kira süresi + on yıllık uzama süresi +1 yıllık izleyen uzama yılı sonunda kira sözleşmesinin sona erdirilebilmesi saikiyle hareket ettiği izlenimi uyanmaktadır. Diğer bir deyişle, örneğin sekiz yıllık ya da on beş y1llık kira sözleşmeleri akdedilmesi halinde on yıllık uzama süresinin bu kira sürelerine ilave edilip edilmeyeceği hususu, kanun koyucu tarafindan ya yeterince üzerinde düşünülüp değerlendirilmemiş ya da düşünülmüş olsa bile, uzun süreli kira sözleşmeleri ile belirsiz süreli kira sözleşmeleri bakımından ortaya çıkan bu büyük zaman farkının yaratacağı ve adalet duygusunu rahatsız edebilen durumlar öngörülememiştir.

Üçüncü olarak, yukarıda da kısmen ifade edildiği üzere, kanun koyucu, belirli süreli kira sözleşmeleri bakımından, tarafların irade özgürlüğü içerisinde kararlaştırdıkları muayyen kira süresine, taraf iradeleri doğrultusunda saygı duymak istemiş ve kanundan doğan on yıllık uzama süresini, bu muayyen kira süresinden itibaren başlatmak istemişse de; kanun koyucunun öngöremediği -özellikle uzun süreli kira sözleşmeleri bakımından- belirsiz kira sözleşmelerine nazaran çok önemli bir zaman farkı ortaya çıkmıştır. Oysa, belirli süreli kira sözleşmelerinin olağan fesih yöntemi ile sona erdirilmesi ile belirsiz süreli kira sözleşmelerinin olağan fesih yöntemiyle sona erdirilmesi bakımından, -özellikle uzun süreli kira sözleşmeleri akdedilmesi 
üzerine- ortaya çıkan bu büyük zaman farkını haklı kılabilecek bir gerekçe mevcut değildir. Diğer bir deyişle, neden belirli süreli kira sözleşmesindeki kiracılar daha fazla korunurken, belirsiz süreli kira sözleşmesinde, kiracılar daha az korunmaktadır? Bir an için, kanun koyucunun tarafların kira süresini kararlaştırmaları halinde, bu iradeye saygı duymak için on yıllık uzama süresini kira süresini müteakiben başlattığ 1 gibi bir gerekçe ileri sürülebilir ise de, bu gerekçe de yeterince ikna edici değildir. Zira kanun koyucu, on yıllık uzama süresini ihdas ederken, on yıllık uzama süresinin mülkiyet hakkını önemli ölçüde sınırlayan bir süre olmayacağı ve böylece kiraya verenin mülkiyet hakkının korunması ile kiracının korunması arasında bir dengenin sağlanmış olacağı fikrinden hareket etmiştir. Şu halde uzun süreli akdedilen kira sözleşmelerinin ortaya çıkardığı büyük zaman farkı, kanun koyucunun madde ile getirmek istediği amaçla uyumlu değildir. Kaldı ki, belirsiz süreli kira sözleşmesinde de, tıpkı belirli süreli kira sözleşmesinde olduğu bir "süre" vardır; sadece bu sürenin ne kadar olacağı belirli değildir. Diğer bir deyişle kanun tarafindan yaratılan bu sathi ve yüzeysel ayrım, aslında her iki türün de süreye tabi olduğu sözleşmeler bakımından ortaya konulmaktadır ki, bunun, hâkim görüş tarafından "birisinde süre kararlaştırılmış, diğerinde ise kararlaştırılmamış” gibi bir gerekçeyle savuşturulması, ikna edici olmaktan uzaktır.

Dördüncü olarak, kiracının ekonomik olarak durumunun kiraya verene nazaran daha zayıf olması temeline dayanan "kirac1 lehine yorum ilkesi" de, her durumda haklı bir sebep oluşturmaz. Giderek öğretide daha çok ifade edilmeye başlandığı üzere, kiracıların ekonomik durumunun kiraya verenden daha iyi olduğu örnekler ve hatta işyeri kiraları bakımından çoğu kere basiretli tacir sıfatını haiz olan kiracılar, uygulamada azımsanmayacak ölçüde karşımıza çıkmaktadır. Öyleyse, tarafların ekonomik durumlarına bakılmaksızın "kiracının korunması" fikri, tek başına bir ilke imiş gibi ele alınmamalı; özellikle TBK m.347 hükmü açısından, "kiraya verenin mülkiyet hakkının sınırlanmasına bir sınır getirilmesi” amaciyla birlikte ele alınmalıdır ve kanun tarafından varsayılan denge göz ardı edilmemelidir. Bir diğer görüşe göre ${ }^{87}$ ise, kiracının korunması düşüncesinin sebebi, kiracının ekonomik olarak zayıf durumda olması değil; "pazarlık gücünün bulunmaması"dır. Kanımızca kira sözleşmesinin hüküm ve koşullarının kendisi için elverişli olmadığını gören kiracı, bu yeri kiralamama ve daha uygun başka bir yer bulma imkânına sahip olup, onun kural olarak pazarlık gücüne sahip olmadığını peşinen kabul etmek isabetli olmaz ${ }^{88}$.

\footnotetext{
87 Akıncı, s.40-41: “Özellikle işyeri kiralarında kiracının ekonomik olarak daha güçlü olması mümkündür. Fakat ekonomik olarak güçlü de olsa, ticari faaliyetini sürdürebileceği işyeri bulmakta zorlukçekiyorsa, pazarlık gücü kalmamış, dolayıslyla irade muhtariyeti ilkesi de zedelenmiş demektir".

88 Bir an için akla, ticaret yapabilmek için AVM'lere girmek ve oradaki sözleşme şartlarını kabul etmek zorunda kalan kiracılar gelebilirse de, bu örneği tüm kiracılar için geçerli bir durum olarak kabul etmek kanımızca isabetli olmaz. Bu gibi haller özelinde, sözleşme yorumlanırken, elbette kiracı lehine yorum ilkesine başvurulmak gerekir. Öte yandan haksız şartlar bakımından genel işlem koşulları denetimi ve Türk Borçlar Kanununun kiracıyı koruyan emredici hükümleri devrede olduğu gibi, ekonomik kişilik haklarını aşırı ölçüde sınırlayan sözleşme hükümleri de kısmi hükümsüzlük yaptırımı ile karşılaşabilir.
} 
Beşinci olarak, uygulamada, özellikle konut kiraları, çok büyük bir oranda bir yıllık "kontrat"lar şeklinde hazırlanmaktadır. Taraflar daha sonra çoğu kere, kira süresini tecil etmek maksadıyla değil; örneğin kira bedelini belirlemek üzere takip eden senelerde yeniden kontratlar yapabilmektedirler. Yargitay, "kontratlar"1n neden yenilendiği araştırmasına hiç girmeden, sürenin tecil edilmiş olacağı ve on yıllık uzama süresinin son tecilin bittiği zamandan itibaren başlayacağı sonucuna varmaktadır ki, bu yaklaşım, hayatın olağan akışındaki kiraya veren - kiracı ilişkilerinin yeterince iyi analiz edilemediğini göstermektedir. Hayatın olağan işleyişi içerisinde çoğu kere sözleşmedeki hiçbir hükme dokunulmayıp, yalnızca bedel değiştirilmektedir. $\mathrm{Bu}$ örneklerde, tarafların sözleşme süresini tecil ederek, on yıllık uzama süresinin başlangıcını da ertelemek iradesi ve niyetiyle hareket ettikleri, otomatik bir sonuçmuş gibi, söylenemez.

Çatılı işyeri kiralarında ise kira süreleri çoğu kere daha uzun (örneğin beş yıllık olarak) akdedilebilmektedir. Zaten çatılı işyeri kiracısı, -ki bu kişi çoğu kere basiretli bir tacir gerçek veya tüzel kişi ya da esnaf olacağına göre- işyerine yapacağı maddi yatırımı ve işyerinin konumunu kanıksayacak müşteri çevresini düşünerek, bir ya da beş yıllık değil; daha uzun süreli (örneğin on yıllık, yirmi yıllık) kira sözleşmeleri akdedebilir. Eğer, çatılı işyeri kiracısı, uzun süreli bir kiralama yapma tercihinde bulunmuyorsa, bunun sonuçlarına katlanmalıdır. Zira kanun koyucu on yıllık uzama süresini, aksi kararlaştırılamaz bir zaman dilimi olarak belirlemiştir. Bu süre, çatılı işyeri kiracısı için yeterli gelmiyorsa, çatılı işyeri kiracısı, örneğin on beş yıllık bir kira sözleşmesi akdedebilir ve kiraya veren bu süre için bir kira sözleşmesi akdetmeye yanaşmiyorsa, o yeri kiralamaktan vazgeçip, serbest piyasa ekonomisi içerisinde uygun bir başka yer kiralama yoluna gidebilir. Çatılı işyeri kiracısının iş yerine yaptığ 1 yatırımın ölçüsü ve müşteri çevresi, o yerden yalnızca kira geliri elde eden kiraya verenin, sözleşmeyi sona erdirmesini geciktirmek için yeterli bir sebep teşkil etmez. Öğretide, olması gereken hukuk anlamında, çatılı işyeri kiraları bakımından kanundaki uzama süresinin on değil; on beş yıl olması gerektiği ileri sürülmüşse $\mathrm{de}^{89}$, ortalama insan ömrünün seksen y1l olduğu varsayılırsa, bu ömrün sekizde biri kadar bir zaman dilimi olan ve kanun tarafından kayıtlanan on yıllık süre, kanımızca yeterli görülmek gerekir. Az önce de ifade edildiği üzere, on yıl yeterli görülmüyorsa, ekonomik kişilik haklarına uygun düştüğü ölçüde, daha uzun kira sözleşmesi akdedilmesine bir engel bulunmamaktadır.

Altıncı olarak, bir an için hâkim görüş kabul edilecek olur ise, uzun süreli olarak kira sözleşmesi ile bağlı kalmak istemeyen kiraya verenler için en sağlıklı yöntem, ya belirsiz süreli kira sözleşmeleri yapmak ya da en çok bir yıllık bir kira sözleşmesi yapmak olacaktır. Oysa tarafların menfaat durumları, daha uzun süreli kira sözleşmesi yapmayı gerektirebilir. Örneğin kiraya verenin, kiracının belirsiz süreli

$89 \quad$ Bu görüşler için bkz. $§ I I$. 
kira sözleşmesi uyarınca fesih dönemlerine uyarak ya da bir yıllık bir sözleşmede bir yılın sonunda her zaman sözleşmeyi sonlandırabilme riski ile karşı karşıya kalmamak için daha uzun süreli kira sözleşmesi yapma konusunda haklı menfaati vardır. Bununla birlikte hâkim görüş kabul edilecek olursa, kiraya veren olağan fesih yöntemi ile kira süresini uzun süreler sonunda ancak sona erdirebilecektir. $\mathrm{Bu}$ durumda hâkim görüşün kabulü, kiraya verene "ya serden ya da yardan vazgeçmesi" yönünde bir seçenek sunmaktadır ki, böyle bir seçim yapma zorunluluğunu haklı kılacak herhangi bir makul sebep mevcut değildir. Hâkim görüşün kabulü halinde, tarafların kira süresini özgürce belirleme hakları üzerinde baskı oluşacak ve sözleşme özgürlüğü dolaylı olarak engellenmiş olacaktır. Herhalde TBK m.347/I, c.3 hükmü ihdas edilirken, böyle bir sonucun doğması arzu edilmiş olamaz.

\section{B. Kanaatimiz}

\section{De Lege Lata Görüşümüz}

\section{a. On yıllık Uzama Süresinin Başlangıcı Bakımından}

Yukarıda öğretideki görüşler ve yargı uygulamasını değerlendirirken, ipuçlarını verdiğimiz üzere, kanaatimizce, TBK m.347/I, c.3 hükmünde yer alan "uzama süresinin", yorum yoluyla, kira süresinin başlangıcından itibaren başlatılması ya da kira süresinin ilk kira yılının bitiminden itibaren başlatılması mümkün gözükmemektedir. Hükmün açı ifadesi, on yıllık uzama süresinin, kira süresinin bitiminden itibaren başlayacağı izlenimi uyandırmaktadır ki, öğretideki hâkim görüş de bu izlenim yönündedir. Ancak hâkim görüşün kabul edilmesi de, kanunun uygulanmasında, özellikle uzun süreli kira sözleşmeleri bakımından, adil olmayan farklıkların doğmasına yol açmaktadır ki, çoğunluk görüşüne de bu sebeple katılmamız mümkün olamamıştır.

Özellikle uygulamada çokça yapılan bir yıllık sözleşmeler bakımından, hâkim görüşün kabul edilmesi, belirsiz süreli sözleşmelerin feshine nazaran çok önemli bir zaman farkı yaratmamaktadır. Ancak, kanımızca, uzun süreli kira sözleşmeleri akdedilmesi halinde ortaya çıkacak adil olmayan sonuçlar, yeterince öngörülememiştir. Maddenin bu haliyle uygulanması, belirli süreli kira sözleşmeleri ile belirsiz süreli kira sözleşmelerinin sona erdirilmesi bakımından, hiçbir haklı sebep olmaksızın, çok önemli zaman farklarının ortaya çıkmasına ve adalet düşüncesine aykırı düşen sonuçlara yol açmaktadır. Hatta Yargitay'ın, tarafların bir kira sözleşmesi yaptıktan sonra, tekrar tekrar sözleşme tazelemeleri halinde, bu durumu, tarafların tecil etme iradesi taşıyıp taşımadıklarını araştırmaksızın, tecil anlaşması sayarak, on yıllık süreyi son tecil süresinin bitiminden itibaren başlatmas ${ }^{90}$, belirli süreli kira sözleşmeleri ile belirsiz süreli kira sözleşmeleri arasındaki bu anlamsız farkı iyice belirginleștiren bir hal almıştır.

\footnotetext{
90 Bkz. yukarıda §V.B, dn.77.
} 
O halde, kanaatimizce, kanun koyucunun, TBKm.347/I, c.3 hükmünü düzenlerken, belirli süreli sözleşmeler ile belirsiz süreli sözleşmeler arasında bir ayrım yapmak istemesine rağmen, -özellikle uzun süreli sözleşmeler bakımından- öngöremediği bir şekilde ve ayrıca hükmün ihdas amacına (ölçülü sınırlama amacına) aykırı düşen adaletsiz sonuçların doğmasına yol açılmış olması gerekçesiyle, kanunda örtülü bir

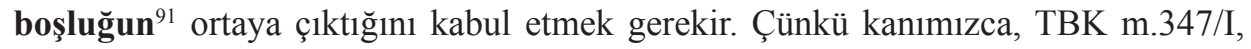
c.3 hükmünün lafzına uygun surette uygulanması, kanunun kiraya veren ile kiracının menfaatleri arasında arzu ettiği dengeyi sağlama ve bu yolla mülkiyet hakkının aşırı ölçüde sınırlanmasına bir sınır getirme amacına aykırı düşmektedir. Kanunun amacının gerçekleştirilmesinin, "yorum" yoluyla sağlanması da mümkün olamamaktadır. Belirli süreli ve belirsiz süreli kira sözleşmeleri arasında oluşturulan ayrımın adalete aykırı sonuç vermesi, TBK m.347/I, c.3 hükmünün "yorumlanması" suretiyle de engellenemeyeceğinden, burada bir örtülü boşluk oluştuğunu savunmaktayız ${ }^{92}$.

Böylece belirli süreli konut ve çatılı işyeri kira sözleşmelerinin kanun lafzına göre "kira süresi + on yıl + bir yıl" sonra kiraya veren tarafından feshedilebileceğini ifade eden kanun hükmü, mülkiyet hakkının sınırlanmasına sınır getirme ve kiracının korunması ilkeleri arasında kanun tarafından varsayılan dengenin sağlanması amacına

$\overline{91}$ Öğretide "örtülü boşluk" teriminden ne anlaşılması gerektiği ve örtülü boşluğun nasıl doldurulması gerektiği tartışmalıdır. Gerçek olmayan boşluk ile örtülü boşluk arasındaki farkın ne olduğu konusunda da öğretide farklı görüşler mevcuttur. Örtülü boşluk kavramı ile ilgili detaylı bilgi ve tartışmalar için bkz. M. Kemal Oğuzman/Nami Barlas, Medeni Hukuk, Giriş, Kaynaklar, Temel Kavramlar, 23.Bası, Vedat, İstanbul, 2017, N.34 1 vd; Mustafa Dural/Suat Sarı, Türk Özel Hukuku, C.1, Temel Kavramlar ve Medeni Kanunun Başlangıç Hükümleri, Filiz, İstanbul, 2018,N.866 vd; Hüseyin Hatemi, Medeni Hukuk'a Giriş, 8.Bası, Oniki Levha, İstanbul 2017, §7, N.61 vd; Rona Serozan, Medeni Hukuk, Genel Bölüm/ Kişiler Hukuku, 8.Bask1, Vedat, İstanbul 2018, §5, N.38 vd; Şener Akyol, Medeni Hukuka Giriş, Vedat, İstanbul, 2006, s.280; Çiğdem Kırca, "Örtülü (Gizli) Boşluk ve Bu Boşluğun Doldurulması Yöntemi Olarak Amaca Uygun Sınırlama (Teleologische Reduktion)”, Ankara Üniversitesi Hukuk Fakültesi Dergisi, C.50, S.1, 2001, s.96; Yasemin Işsktaç/Sevtap Metin, Hukuk Metodolojisi, Filiz, İstanbul 2010, s.229; Pakize Ezgi Akbulut, Borçlar Hukukunda Kesin Hükümsüzlük Yaptırımının Amaca Uygun Sınırlama (Teleolojik Redüksiyon) Yöntemi İle Daraltılması, Oniki Levha, İstanbul, 2016, s.84 vd, 94 vd, 100 vd; Haluk Nami Nomer/Pakize Ezgi Akbulut, Medeni Hukuka Giriş Dersleri, Bölüm I, 2.Baskı, Filiz, İstanbul 2018, N.162 vd, 176 vd; Sururi Aktaş, "Pozitif Hukukta Boşluk Kavramı”, Erzincan Üniversitesi Hukuk Fakültesi Dergisi, C.49, S.1-2, 2010, s.20.

Örtülü boşluk kavramı ve örtülü boşluğun doldurulması ile ilgili tartışmalar, bu çalışmamızın kapsamını aşmaktadır. Ancak burada şu kadarına değinmek gerekir ki, biz, örtülü boşluğu, kanunda somut olaya uygulanabilir bir hüküm bulunmasına rağmen, hükmün amacı dikkate alındığında, hükmün somut olaya uygulanmasının uygun olmaması şeklinde anlamaktayız. $\mathrm{Bu}$ bağlamda hükmün amaca uygun olarak sınırlanması gereken hallerde (teleolojik redüksiyon), örtülü bir boşluk söz konusu olur. Örtülü boşluğun nasıl doldurulması gerektiği konusunda öğretide savunulan görüşler içerisinde; kanunun amaca göre sınırlanması suretiyle örtülü boşluğun doldurulmasının, TMK m.1/II uyarınca hâkimin hukuk yaratması yoluyla gerçekleştirilebileceği, yolundaki görüşü kabul ediyoruz. Bu yönde bkz. Akbulut, s.94; Nomer/Akbulut, N.179.

${ }_{92}$ Kırca'nın da belirttiği üzere, “örtülü boşluk durumunda, kanunda somut olaya uygulanması mümkün bir kuralın açıcça düzenlenmis olduğu görülmektedir, ancak kanunun amacı ve ruhu esas alındı̆̆ında, düzenleme somut olaya uygun değildir. Çünkü kanun, söz konusu olayların değerlendirmesinde önem taşıyan bazı özellikleri dikkate almamıştır. Kanunun lafž çok geniş olup, tüm daraltıcı yorum çabalarına rağmen, somut olayın istisnai özelliklerine uymamakta, adalete aykırı sonuçlar doğurmaktadır".

Öğretide, TMK m.2/II gereğince hükmün uygulanmasının ancak hakkın kötüye kullanılması teşkil etmesi halinde örtülü boşluğun söz konusu olabileceği ve bu halde hâkimin mevcut hükmü dürüstlük kuralı (TMK m.2) yardımıyla düzelterek uygulayacağı, yoksa TMK m.1/II gereğince hukuk yaratamayacağı yolunda görüşler ileri sürülmüş ise de, bizim katıldığımız görüșe göre örtülü boşluk doldurma doğrudan TMK m.1/II hükmüne dayanır. Nitekim bu görüşteki Akbulut'un da belirttiği üzere, “(...) örtülü boşluğun bulunduğu hallerde hakkın kötüye kullanımı yasağına başvurulmadan da hükmün amacı doğrultusunda birtakım sonuçlar elde edilebilecektir. Zira (...) gerçek olmayan ya da örtülü boşluk görüşleri doğrultusunda gerek kanundaki baskl, çeviri hataları nedeniyle gerekse sonradan ortaya çıkmış sebepler veya kanun koyucunun önceden öngöremediği (gözden kaçırdığı) durumlarda oluşan istisnai hallere ilişkin düzenleme eksikliklerinde boşluk bulunduğunun kabul edilmesinin sebebi; somut olay çerçevesinde hükmün lafżnın, kanunun ratio legis'ine uymamasıdır" (s.94). [Alıntılanan metindeki vurgu tarafımızca yapılmıştır]. 
göre sınırlanmalıdır (teleolojik redüksiyon). Elbette amaca göre sınırlandırma suretiyle örtülü boşluğun doldurulması faaliyetinde hâkim, kıyas (analogy) yöntemine de başvurabilir. Kanaatimizce, söz konusu boşluk, TBK m.347/II hükmünün kıyasen uygulanması yoluyla doldurulmalıdır. Buna göre, kanun boşluğunun, taraflar daha uzun bir kira sözleşmesi kararlaştırmadıkları sürece, belirli süreli kira sözleşmelerinin kiraya veren tarafından, en erken, kira sözleşmesinin başlangıç tarihinden itibaren on yıllık sürenin sonunda ve bundan sonraki her uzama yılının sonunda -bu sürelerden en az üç ay önce bildirimde bulunmak kaydıyla- bildirim yoluyla feshedilebilmesine imkân sağlamak suretiyle doldurulması gerekir ${ }^{93}$. Örneğin 2015 yılında akdedilen 5 y1l süreli bir konut ve çatılı işyeri kira sözleşmesinde, kiraya veren, bildirim süresine uymak kaydıyla, en erken 2025 yılının sonunda fesih hakkını kullanabilmelidir.

\section{b. Tarafların On Yılı Aşan Bir Süre İle Sözleşme Akdetmiş Olmaları Halinde Durum}

Şayet, taraflar on yılı aşan bir süre için kira sözleşmesi akdetmiş iseler, bu kere, kanaatimizce, kanundan doğan on yıllık uzama süresini aşan bu iradi süre, kanundan doğan sürenin yerini alır. Meğerki TMK m.23/II hükmüne aykırı düşecek ölçüde uzun süreli bir sözleşme akdedilmiş olsun ${ }^{94}$. Örneğin 2015 yılında 15 y1l süreli olarak akdedilen bir konut ve çatılı işyeri kirasında, kiraya veren, bildirim süresine uymak kaydıyla, en erken, 2030 yılının sonunda fesih hakkını kullanabilecektir.

93 Bizim savunduğumuz görüş, Zevkliler/Gökyayla tarafından savunulan görüş ile aynı sonuca varmakta ise de, biz, yorum yoluyla değil; kanun boşluğu olduğu gerekçesiyle boşluğun doldurulması yöntemi olarak bu sonuca aynı sonuca varmaktayı.

94 TMK m.23/II hükmüne aykırı düşecek ölçüde uzun süreli olan ya da kelepçeleme sözleşmesi niteliği arz eden bir kira sözleşmesinin ne kadar süreli olması gerekeceği hakkında on yıl, yirmi yıl, otuz yıl gibi net bir rakam verilemez. Kira süresi ile birlikte kira bedeli, taraflara sözleşme ile yüklenen yükümlülükler gibi diğer koşullar da bir arada değerlendirilerek sonuca varılması gerekir. Ayrıca bu durum, sadece kira sözleșmesi özelinde değil, diğer sözleșmeler için de söz konusu olabilecek ayrı bir konudur. Kelepçeleme sözleşmeleri ile ilgili detaylı bilgi için bkz. Necip Kocayusufpaşaoğlu/Hüseyin Hatemi/Rona Serozan/Abdulkadir Arpacı, Borçlar Hukukuna Giriș, Hukuki İşlem, Sözleșme, 4. Bası'dan 7. Tıpkı Bası, İstanbul, Filiz, 2017, s.576 vd; M. Kemal Oğuzman/ Özer Seliçi/ Saibe Oktay-Özdemir, Kișiler Hukuku (Gerçek ve Tüzel Kişiler), 17.Baskı, Filiz, İstanbul, 2018, s.211 vd; Veysel Başpınar, "Kişilik Hakkı Açısından Kelepçeleme Sözleşmeleri”, Ankara Barosu Dergisi, S.1, 1999, s.25; Karabağ Bulut, s.144 vd; Akın Ünal, Kelepçeleme Sözleşmeleri: Sözleşmelerdeki Hükümler Sebebiyle Kişinin Ekonomik Özgürlüğünün Aşırı Derecede Sınırlanması, 2.Baskı, Adalet, Ankara, 2017, s.174 vd; ayrıca bkz. Y.13HD 03.10.1995, 6697/8386 (Kazanc1 İBB).

Yargıtay, kira sözleşmesinin çok uzun süreli olmasını, tek başına sadece süreyi nazara alarak, ekonomik kişilik haklarının aşırı ölçüde sınırlanması bağlamında bir kısmi geçersizlik (TMK m.23/II, TBK m.27/II) (kelepçeleme sözleşmesi) hali olarak değerlendirmemektedir. Yargıtay'ın TBK m.347 hükmünün yürürlükte olmadığı (kiraya verenin olağan fesih hakkının bulunmadığı) 2002 yılına ait bir kararında, uzama süreleri de dâhil kırk yıllık süredir devam eden bir kira ilişkisi bakımından mülkiyet hakkının özüne dokunulmadığı sonucuna varılmıştır. Bkz. Y.13HD 04.03.2002, 10836/20113 (Kazanc1 İBB).

Buna karș1lık aksi görüș için bkz. Gülșah Sinem Aydın, Kira Sözleșmesinin Genel Hükümlere Göre Sona Ermesi (TBK m.327-333), 1. Bası, On İki Levha Yayınları, İstanbul 2013, s.51. Yazara göre, “(...) gerek TBK m. 347/I gerek TBK m.430/ III gerekse de TBK m.598/III hükümlerinde, on yılı aşkın süreyle bir tarafi sözleşme ile bağlı tutmak, kişisel özgürlüğü aşır biçimde sinırlama olarak görülmüş ve taraflara on yıldan sonra sözleşme ile bağlı olmama hakkı tanınmıştır. Şu halde Türk Borçlar Kanunu'nun ratio legisine göre kişisel özgürlüklerin sözleşme yolu ile aşırı biçimde sınırlanması hususunda on yılın azami bir sınır olarak kabul edildiği söylenebilir. Buradan yola çıkarak kanımızca sonsuz ya da çok uzun süreli kira sözleşmeleri de dikey kısmî hükümsüzlük yaptırımı sonucunda on yıl ile sınırlanmalıdır".

Ekleyelim ki İsviçre Türk Hukukunda yer almayan bir düzenleme olarak Alman Medeni Kanunun 544.maddesinde, çok uzun süreli bir kira sözleșmesi yapılmış olsa da, 30 yıl geçtikten sonra tarafların sözleşmeyi feshetme hakkına sahip oldukları düzenlenmiştir. 


\section{c. Kiraya Verenin Fesih Bildiriminde Bulunarak Sözleşmeyi Sona Erdire- bileceği En Erken Zaman Diliminin On yıllık Uzama Süresinin Son Yılı mı, Yoksa On yıllık Uzama Süresini Takip Eden Uzama Yılı mı Olduğu}

TBK m.347/I, c.3'deki “(...) on yıllık uzama süresi sonunda kiraya veren, bu süreyi izleyen her uzama yllının bitiminden en az üç ay önce bildirimde bulunmak koşuluyla, (...) sözleşmeye son verebilir" hükmünün lafzından, fesih hakkının en erken, on yıllık uzama süresini takip eden uzama yılının sonunda kullanılabileceği anlaşılmakta ise de, kanımızca, örtülü boşluğun kıyasen TBK m.347/II hükmü uygulanmak suretiyle uygulanmak suretiyle doldurulması gerekeceğinden; kiraya veren, kira sözleşmesini en erken kira başlangıç tarihinden itibaren onuncu yılın sonunda ve izleyen her uzama yılının sonunda -bu sürelerden en az üç ay önce bildirimde bulunmak kaydıylafeshedebilmelidir.

\section{d. Tarafların, Mevcut Kira İlişkisi Devam Ederken Yeni Bir Kira Sözleşmesi ("kontrat") Akdetmeleri Hali}

Bir kira sözleşmesindeki kira süresi henüz dolmadan ve uzama yıllarına geçilmeden önce ya da kira süresi dolduktan ve uzama yıllarına geçildikten sonra, taraflar bir araya gelerek yeni bir kira sözleşmesi ("kontrat") akdedebilirler ${ }^{95}$. Böyle bir davranışın amacı, mevcut kira sözleşmesindeki bedele ilişkin hükmü veya süre dışındaki başkaca bazı hükümleri değiştirmek olabileceği gibi süreyi yeniden belirlemek (tecil anlaşması yapmak) ya da yenileme (tecdit) anlaşması yapmak da olabilir.

Hemen belirtelim ki, kira sözleşmesinin devredildiği hallerde (TBK m.323) kira sözleşmesini devralan kişi ile kiralananın kanun gereği el değiştirdiği hallerde (TBK m.310) yeni malik; mevcut ve devam etmekte olan kira sözleşmesine dâhil olduklarından, yeni bir kira sözleşmesi akdedilmesi durumu söz konusu değildir. Bu hallerde, mevcut ve devam etmekte olan sözleşmenin hükümleri aynen yürür ve başlamış olan uzama süresi de taraf değişikliklerinden etkilenmeksizin aynen devam eder. Dolayısıyla bu haller, bu başlıkta ele alınan konunun dışındadır.

\section{1) Tarafların mevcut kira sözleşmesindeki kira süresi dolmadan önce yeni bir kira sözleşmesi akdetmeleri hali bakımından}

Tarafların mevcut kira sözleşmesindeki işlemekte olan kira süresi henüz tamamlanmadan yeni bir kira sözleşmesi akdetmeleri halinde, kanaatimizce, taraf iradelerinin yorumu ile bir sonuca varmak gerekir. Olayların büyük çoğunluğunda tarafların yalnızca kira bedeline ilişkin hükmün belirlenmesi açısından yeni bir sözleşme ("kontrat") akdettikleri görülmektedir. Tarafların kira sözleşmesinin süre dışındaki başkaca bazı hükümlerinde değişiklik yapma (tadil) arzusu ile hareket etmeleri de söz konusu olabilir. Böylesi hallerde, taraf iradelerinin, yürümekte olan

\footnotetext{
Bu konudaki görüşlere yukarıda değinmiştik: Bkz yukarıda §V.A ve B.
} 
kira sözleşmesini sona erdirip, yeni bir kira sözleşmesi akdetmek yönünde olduğu söylenemez. Bu gibi hallerde, akdedilen sözleşmenin yeni bir sözleşme olmadığını; gerçek ve ortak taraf iradelerinin yalnızca mevcut kira sözleşmesindeki bedele ilişkin hükmü veya başka bazı hükümleri değiştirmek yönünde olduğunu kabul etmek gerekir (TBK m.19). Böylece, işlemekte olan kira süresi ve on yıllık uzama süresi bu hüküm değişikliklerinden etkilenmeyecektir. Zira ortada esasen "yeni” denilecek bir sözleşme olmayıp; mevcut sözleşmenin bazı hükümler yönünden tadili söz konusudur.

Şayet taraflar, kira süresi henüz devam ederken, yeni bir sözleşme ("kontrat") akdetmek suretiyle yeni bir kira süresi belirlemekte iseler; bu durumda mevcut kira sözleşmesinin, kira süresi yönünden tadil edildiği (tecil anlaşması yapıldığı) kabul edilmek gerekir. Öğretide on yıllık sürenin başlangıcı konusunda savunulan farklı görüşlere göre, tecilin on yıllık uzama süresine etkisinin farklı olacağına yukarıda değinmiştik ${ }^{96}$. Kanaatimizce, taraflar eğer, kira süresini tecil etmek ortak amaciyla ve iradesiyle yeni bir kira süresi öngörerek yeni bir sözleşme yapmakta iseler, bu durumda, on yıllık sürenin, yeni hazırlanan sözleşmeye göre başlaması gerekir ${ }^{97}$. Bizim görüşümüz, TBK m.347/I, c.3 açısından bir örtülü kanun boşluğunun bulunduğu yönünde olduğundan, bu görüşümüze uygun bir sonuç olarak, mevcut kira sözleşmesindeki kira süresinin tecil edilmesi halinde yeni belirlenen kira süresinin başlangıcından itibaren on yıllık sürenin hesaplanması gerekir. Diğer bir deyişle adeta kira sözleşmesinin başlangıç tarihi kaydırılmış gibi, on yıllık sürenin yeni kira sözleşmesinin başlangıcı tarihinden itibaren hesaplanması gerekir ${ }^{98}$. Örneğin 2015 yılında akdedilen 3 yıllık bir kira sözleşmesi 2016 yılında tecil edilerek 5 yıllık bir süre kararlaştırılmışsa; yeni kira süresi 2016 tarihinden itibaren 5 yıldır. Kiraya verenin fesih hakkı ise, bildirim süresine uymak kaydıyla, en erken 2016 y1lından itibaren on yılın sonunda; yani 2026 y1lının sonu itibariyle kullanılabilecektir. Görüşümüz doğrultusunda, tecil değil, yenileme (tecdit) söz konusu olan hallerde de on yıllık sürenin, yeni kira sözleşmesinin başlangıcından itibaren hesaplanması gerekir; böylece yapılacak hesaplama, tecil halinde yapılan hesaplama ile ayniyet arz etmektedir.

\footnotetext{
Bkz. yukarıda $§$ V.A.

${ }_{97}$ Yalnız önemle vurgulayalım ki, somut olayların çoğunda, kiraya veren ve kiracı, her yıl kırtasiyelerden bile temin edilebilen kontratlar imzalayarak, sözleșme bedelini yeniden belirlemek niyetiyle hareket etmektedirler. Bu kontratlarda sadece bedele ilişkin kısım değişmekte, diğer hükümlere dokunulmamaktadır. Böylece sözleşmede yer alan "kira süresi: 1 yıldır" ibaresi de aynen yeni kontratlarda da kalmaya devam etmektedir. İște bu örneklerde, tarafların sözleșmeyi tecil etmek maksadıyla hareket ettikleri, kural olarak, söylenemez; en azından karine olarak kabul edilemez. Tarafların ortak ve gerçek amaçlarına göre yorum yapılması gerekir (TBK m.19). Kira süresi bir yıldır ibaresinin her kontratta yeniden yazılması, geri planında bir tecil iradesi taşımamakta, mevcut kontratın matbu metninde yer alan bir ibare olarak kalmaya devam etmektedir. Meğerki tarafların gerçekten de bir yıllık bir tecil anlaşması maksadıyla hareket ettikleri anlaşılsın.

98 Kabul ettiğimiz görüşe göre, örtülü boşluk gerekçesiyle on yıllık sürenin, daha uzun bir süre kararlaştırılmış olmadıkça, kira sözleşmesinin başlangıcından itibaren hesaplanması gerektiğini savunmaktayız. Ancak bu görüşümüz, bütünüyle taraf iradelerinin göz ardı edilmesi anlamına gelmemektedir. Bu sebeple, tıpkı on yıldan uzun süreli kira sözleşmesi yapılması halinde fesih tarihinin bu sürenin sonunda olacağını savunduğumuz gibi, bu kez de tecil anlaşması olması durumunda yine taraf iradelerine değer vererek, on yıllık sürenin tecilin başlangıcı tarihinden itibaren (yoksa tecil edilen sürenin sonundan itibaren değil(!)) on yıllık sürenin hesaplanması gerektiği görüşündeyiz.
} 


\section{2) Tarafların, mevcut kira sözleşmesindeki on yıllık uzama süresi devam et- mekte iken, yeni bir kira sözleşmesi akdetmeleri hali bakımından durum}

$\mathrm{Bu}$ başlık altında ele aldığımız konunun, yukarıdaki başlık altında incelenen konudan farkı şudur: Yukarıda, henüz kira süresi devam ederken bir tecil anlaşması yapılmaktadır. Oysa bu burada incelenen konu, kira süresinin sona erdiği ve kanundan doğan uzama yıllarına geçildiği bir dönemde yeni bir kira sözleşmesinin yapılmasıdır. Ancak, burada incelenen konu açısından da, yukarıdaki savunduğumuz görüşler aynen geçerlidir. Şöyle ki:

Kanaatimizce, mevcut kira sözleşmesindeki on ylllık uzama süresi henüz devam etmekte iken, tarafların bir araya gelerek yeni bir kira sözleşmesi akdetmeleri halinde, on yıllık uzama süresinin akıbeti hakkında taraf iradelerinin yorumu ile bir sonuca varmak gerekir. Tarafların kira sözleşmesinin bedel hükmünde veya süre dışındaki başkaca bazı hükümlerinde değiş̧iklik yapma (tadil) arzusu ile hareket etmeleri hallerinde, taraf iradelerinin, yürümekte olan kira sözleşmesini sona erdirip, yeni bir kira sözleşmesi akdetmek yönünde olduğu söylenemez. Bu gibi hallerde, akdedilen sözleşmenin yeni bir sözleşme olmadığını; gerçek ve ortak taraf iradelerinin yalnızca mevcut kira sözleşmesindeki bedele ilişkin hükmü veya başka bazı hükümleri değiştirmek yönünde olduğunu kabul etmek gerekir (TBK m.19).

Şayet taraflar, on yıllık uzama süresi devam etmekte iken, sonradan yaptıkları yeni bir anlaşma ile, yeni bir kira süresi belirlemek ya da kira ilişkisinin daha ne kadar devam edeceğini belirlemek istemişlerse, bu durumda kural olarak taraf iradelerine saygı duyulması gerekir. Taraf iradelerinden aksi anlaşılmadıkça, on yıllık uzama süresinin başlangıcının, -tıpkı yukarıdaki konuda savunduğumuz üzere- yeni kira süresinin başlangıcı olan tarih olması gerekir. Tarafların kararlaştırdıkları yeni süre, on yıllık sürenin üzerinde ise, bu yeni sürenin sonunda, kiraya veren tarafindan fesih hakkının kullanılabileceğini kabul etmek gerekir. Örneğin, 2015 y1lında bir yıllık süre için akdedilen kira sözleşmesinin üçüncü uzama yılı olan 2019'da taraflar bir araya gelerek kira sözleşmesinin 8 yıl daha süreceğini kararlaştırmış iseler; yeni kira süresinin başlangıç tarihi olan 2019'dan itibaren işleyecek on yılın sonu olan 2029 yılının sonunda sözleşme kiraya veren tarafından -bildirim süresine uymak kaydıylafeshedilebilecektir.

Öte yandan tarafların ortak iradelerinin yorumundan, mevcut kira sözleşmesinin bütünüyle ortadan kaldırılarak, yerine yeni bir kira sözleşmesi yapılması (novatio) arzusu açıkça anlaşılmakta ise, bu haller için, artık tarafların yeni bir kira sözleşmesi ile bağlanma iradesi içerisinde oldukları sonucu doğacağından, bu durumda da on yıllık sürenin yeni kira sözleşmesinin başlangıcından itibaren yeniden başlatılması gerekir. 


\section{De Lege Ferenda Görüşümüz}

Yukarıda yürürlükte olan hukuk açısından, TBK m.347/I, c.3 hükmü bakımından örtülü boşluk olduğunu savunmuş ve kanun boşluğunun TBK m.347/II hükmünün kıyasen uygulanması suretiyle doldurulması gerektĭgini; böylece belirli süreli sözleşmeler ile belirsiz süreli sözleşmeler arasında ortaya çıkan adalete aykırı durumun giderilmiş olacağını belirtmiştik.

De lege ferenda olarak ise TBK m.347 hükmünde değişiklik yapılması gerektiğini savunmaktayı. Kanaatimizce, kanun koyucu tarafindan kiraya verenin sebep göstermeksizin (olağan) fesih hakkını kullanabilmesi bakımından, belirli süreli ve belirsiz süreli kira sözleşmeleri bakımından bir fark yaratılmasının, makul sayılabilecek haklı ve adil bir gerekçesi bulunmamaktadır. Bu sebeple de TBK m.347 hükmünde yapılacak kanun değişikliği ile, gerek belirli süreli kira sözleşmelerinin, gerekse belirsiz süreli kira sözleşmelerinin, en erken, kira süresinin başlangıcından itibaren işleyecek on yıllık uzama süresinin sonunda ve izleyen her bir uzama yılının sonunda -bu sürelerden en az üç ay önce bildirimde bulunmak koşuluyla- kiraya veren tarafından feshedilebileceğinin hükme bağlanması isabetli olur.

Öte yandan mevcut kira ilişkisi devam ederken, kiraya verenin ve kiracının yeniden sözleşme yapmaları halinde, karine olarak, önceki sözleşmeye göre işleyen on yıllık uzama süresi devam ettiği kabul edilmelidir. Şayet tarafların ortak iradesinin yorumundan mevcut kira sözleşmesini tecil etmek istedikleri ya da sözleşmeyi yenilemek (tecdit etmek) istedikleri açık bir şekilde anlaşılıyorsa, on y1llık süre yeni kira süresinin başlangıcı tarihinden itibaren işlemeye başlamalıdır.

Buna göre, önerdiğimiz değişiklik sonrasında TBK m.347/I hükmünün metni şu şekilde değiştirilmeli ve maddeye belirli süreli sözleşmeler açısından aşağıdaki gibi yeni bir fikra eklenmelidir"99:

"Konut ve çatılı işyeri kiralarında kiracı, belirli süreli sözleşmelerin süresinin bitiminden en az $\ddot{u} c ̧ \boldsymbol{y}^{100}$ önce bildirimde bulunmadıkça, sözleşme aynı koşullarla bir yıl için uzatılmış sayllır. Kiraya veren, sözleşme süresinin bitimine dayanarak sözleşmeyi sona erdiremez. Ancak, taraflar daha uzun bir kira sözleşmesi kararlaştırmış olmadıkça, sözleşme ile kararlaştırılan kira süresinin başlangıcından itibaren işleyecek on yıllık sürenin sonunda kiraya veren, en az ü̧̧ ay önce bildirimde bulunmak koşuluyla, herhangi bir sebep göstermeksizin sözleşmeye son verebilir. Kiraya veren on ylllk süreyi izleyen her uzama yllının bitiminden sonra da, yine bildirim süresine uymak koşuluyla, herhangi bir sebep göstermeksizin sözleşmeye son verebilir.

\footnotetext{
99 Değişiklik önerilen ifadeler metinde vurgulanmıştır.

$100 \mathrm{Bu}$ çalışmamızda incelediğimiz konunun dışında kalmakla birlikte, burada yeri geldiğinden belirtelim ki, kanımızca kiracının fesih bildirimi için uyması gerekli olan ve kanunda düzenleme bulan on beş günlük süre, kiraya verenin, bu esnada yeni bir kiracı bulması açısından oldukça yetersiz bir zaman dilimidir. Bu sebeple de, tıpkı kiraya verenin fesih bildirim süresi bakımından kiracıya tanınan üç aylık süre ile yaratılan zaman genişliğinde olduğu gibi, aynı zaman genişliğinin kiracının fesih bildirimi açısında bu kere kiraya verene tanınması gerekir.
} 
Tarafların mevcut kira ilişkisi devam ederken, yeniden sözleşme yapmaları halinde, karine olarak, önceki sözleşmeye göre işleyen on ylllık uzama süresi devam eder. Şayet tarafların ortak iradesinden mevcut kira sözleşmesini tecil etmek istedikleri ya da sözleşmeyi yenilemek (tecdit etmek) istedikleri açık bir şekilde anlaşıllyorsa, on yıllık süre yeni kira süresinin başlangıcı tarihinden itibaren ișlemeye başlar”.

\section{Kisaltmalar Cetveli}

$\begin{array}{ll}\text { AVM } & \text { : Alışveriş Merkezi } \\ \text { AYM } & \text { : Anayasa Mahkemesi } \\ \text { bkz. } & \text { : Bakınız } \\ \text { C. } & \text { : Cilt } \\ \text { c. } & \text { : Cümle } \\ \text { dn. } & \text { : Dipnotu } \\ \text { E. } & \text { : Esas } \\ \text { eBK } & \text { : Mülga } 818 \text { sayılı Borçlar Kanunu }\end{array}$

Ed. $\quad$ : Editör

f. $\quad:$ Fikra

GKHK : Mülga 6570 sayılı Gayrimenkul Kiraları Hakkında Kanun

HMK : $\quad: 6100$ sayılı Hukuk Muhakemeleri Kanunu

İIK : : 2004 sayll İ́cra ve İflas Kanunu

K $\quad:$ Kanun(u)

K. $\quad$ : Karar

karş. : Karşılaştırınız

m. $\quad$ : Madde

N. : Numara

N. $\quad$ : Paragraf numaras 1

RG : Resmi Gazete

S. $\quad$ : Say 1

s. $\quad$ : Sayfa

TBK : : 6098 sayılı Türk Borçlar Kanunu

TMK : 4721 sayılı Türk Medeni Kanunu

TBMM : Türkiye Büyük Millet Meclisi

vd : ve devamı

vs. $\quad$ : Ve saire

Y.HD : Yargitay Hukuk Dairesi

Yürürlük K : 6101 sayılı Türk Borçlar Kanununun Yürürlüğü ve Uygulama Şekli Hakkında Kanun

$\S \quad$ : Bölüm 


\section{Kaynakça/References}

ACAR, Faruk: Kira Hukuku Şerhi (TBK m. 299-326), 4. Baskı, Beta, İstanbul 2017 [Şerh].

ACAR, Faruk: "Belirli Süreli Konut ve Çatılı İşyeri Kira Sözleşmelerinin Yenilenmesi Halinde Kiraya Verenin On Yıllık Sürenin Bitmesi Sebebiyle Bildirim Yoluyla Sözleşmeyi Sona Erdirmesi", Yargıtay Uygulaması Çerçevesinde Borçlar Hukuku ve Eşya Hukukundaki Güncel Gelişmeler Ulusal Sempozyumu, Bildiri Özetleri, 2 Kasım 2018, Yeditepe Üniversitesi, İstanbul 2018, s.10. [Sempozyum] $]^{101}$

AKBULUT, Pakize Ezgi: Borçlar Hukukunda Kesin Hükümsüzlük Yaptırımının Amaca Uygun Sınırlama (Teleolojik Redüksiyon) Yöntemi İle Daraltılması, Oniki Levha, İstanbul, 2016

AKGÜN AKAY, Merve: Konut ve Çatılı İşyeri Kira Sözleşmelerine Özgü Sona Erme Sebepleri, Seçkin, Ankara 2017.

AKINCI, Şahin: "İşyeri Kiralarında Kiracının Korunması Açısından Borçlar Kanunu Tasarısının Bazı Hükümlerinin Değerlendirilmesi”, Ankara Üniversitesi Hukuk Fakültesi Dergisi, C.57, S.3, 2008, s.33-50.

AKKANAT, Halil: "Kira Sözleşmesinin Sona Ermesi”, Türk Borçlar Kanunu Sempozyumu: Makaleler-Tebliğler, Ed. Murat İnceoğlu, Oniki Levha, İstanbul, 2012, s.261-272.

AKTAŞ, Sururi: "Pozitif Hukukta Boşluk Kavramı", Erzincan Üniversitesi Hukuk Fakültesi Dergisi, C.49, S.1-2, 2010, s.1-28.

AKYİĞİT, Ercan: 6098 sayılı Türk Borçlar Kanunu'nda Kira Sözleşmesi, Seçkin, Ankara 2012.

AKYOL, Şener: Medeni Hukuka Giriş, Vedat, İstanbul, 2006.

ANTALYA, Gökhan: "Türk Borçlar Kanunu Tasarısının Değerlendirilmesi Sempozyumu, Dördüncü Oturum: Kira Sözleşmesi ve Kefalet, Legal Hukuk Dergisi, C.3, S.34, 2005, s.3698-3702.

ARPACI, Abdülkadir: "Yeni Borçlar Kanununun Getirdiği Değişiklikler", İstanbul Barosu Staj Eğitim Merkezi, Cumartesi Forumları- 4, İstanbul Barosu, Ege Basım, İstanbul 2012, s.47-104.

AYANOĞLU MORALI, Ahu: "Konut ve Çatılı İşyeri Kiralarında Kiraya Verenin TBK m.347 Çerçevesinde Kira Sözleşmesini Bildirim Yoluyla Sona Erdirmesi”, Bahçeşehir Üniversitesi Hukuk Fakültesi Kazancı Hakemli Hukuk Dergisi, C.9, S.103-104, 2013, s.108-131. [TBK 347].

AYANOĞLU MORALI, Ahu: "Konut ve Çatılı İşyeri Kiralarında Sözleşmenin Sona Ermesi m.347-349”, İstanbul Şerhi Türk Borçlar Kanunu, Yürürlük Kanunu, C.II, Özel Borç İlişkileri, Ed. Rona Serozan, Turgut Öz, Faruk Acar, Emre Gökyayla, H. Murat Develioğlu, 2.Bask1, Vedat, İstanbul, 2018, s.2123-2182. [Şerh]

AYDEMİ, Efrail: Türk Borçlar Yasasına Göre Kira Hukuku, 4.Baskı, Seçkin, Ankara 2016.

AYDIN, Gülşah Sinem: Kira Sözleşmesinin Genel Hükümlere Göre Sona Ermesi (TBK m.327333), 1. Bas1, On İki Levha Yayınları, İstanbul 2013.

AYDOĞDU, Murat/KAHVECI, Nalan: Türk Borçlar Hukuku Özel Borç İlişkileri: Sözleşmeler Hukuku, 3.Bask1, Adalet, Ankara, 2017.

BARLAS, Nami: "Yeni Borçlar Kanunu Tasarısının Getirdikleri”, Güncel Hukuk Dergisi, S.17, 2005, s.20 vd; Makalelerim, C.1, İstanbul 2008, s. 263-270.

BAŞPINAR, Veysel: "Kişilik Hakkı Açısından Kelepçeleme Sözleşmeleri”, Ankara Barosu Dergisi, S.1, 1999, s.19-34.

101 Sempozyum bildirilerinin özeti yayınlanmış olmakla birlikte, işbu makalemizin hazırlandığı tarihlerde bildiri kitabının kendisi henüz yayınlanmamış olduğundan, bildiri özet metnine atıf yapılmıştır. 
BİRINCİ UZUN, Tuba: "Belirli Süreli Konut ve Çatılı İşyeri Kira Sözleşmelerinin Kiraya Veren Tarafından Bildirim Yoluyla Sona Erdirilmesinde On Yıllık Uzama Süresi (TBK md. 347 f.1)", İnönü Üniversitesi Hukuk Fakültesi Dergisi, C.8, S.2, 2017, s.137-158.

BURCUOĞLU, Haluk: “Borçlar Kanunu Tasarısı'nın Haksız Eylem Sorumluluğu ve Kira İle İlgili Düzenlemesiyle Getirilen Yenilikler”, Prof. Dr. Turgut Akıntürk’e Armağan, Beta, Ankara, 2008, s.17-46. [Tasar1]

BURCUOĞLU, Haluk: in "Seminer: Borçlar Kanuna Getirilen Yenilikler" (Prof. Dr. Haluk Burcuoğlu - Prof. Dr. Atilla Altop Yrd. Doç. Dr. Ebru Ceylan - Av. Umut Yeniocak Av. Tamer Şahin), İzmir Barosu Dergisi, C.77, S.2, 2012, s.9-94. [Seminer]

BURCUOĞLU, Haluk: Uygulama ve Öğretiden Örneklerle Özel Hukukta (Aile-Kira-Borçlar Hukukunun Diğer Bazı Bölümleri) I. Quo Vadis (Nereye) II. Nihayet (TBK.'nun her nedense unutulan hükümleri uygulanmaya başland1), 1. Bası, Vedat Kitapçılık, İstanbul 2016. [Quo Vadis]

CERAN, Mithat: “6098 Sayılı Türk Borçlar Kanunu'nda Kira Sözleşmesi”, 6098 Sayılı Türk Borçlar Kanunu Sempozyumu, 12-13 Mayıs 2011, Ankara Barosu, Ed. Emel Badur, Salmat Basım Yayım, Ankara 2011, s.139-154. [BK Sempozyumu]

CERAN, Mithat: “6098 Sayılı Türk Borçlar Kanunu’nda Kira Sözleşmesi”, Hukuk Muhakemeleri Kanunu ve Borçlar Kanunu Sempozyumu, 24-25 Mart 2011, Ankara Barosu, Ed. Emel Badur, Başak Matbaacılık, Ankara 2011, s.235-249. [HMK-BK Sempozyumu]

CERAN, Mithat: Kira Sözleşmeleri Tahliye ve Tesbit Davaları, 2.Bask1, Yetkin, Ankara, 2015.

DAŞLI, Engin: 6098 Sayılı Türk Borçlar Kanunu Hükümlerine Göre Kira Sözleşmesinin Feshi, 1. Bas1, Aristo Yayınc1lık, Erzincan 2017.

DEMİRCIOĞLU, Huriye Reyhan: “6098 Sayılı TBK’ya Göre Konut ve Çatılı İşyeri Kiralarında Kiraya Verenin Bildirimli Fesih Hakkını Kullanabilmesinde Süre Sorunu”, Banka ve Ticaret Hukuku Dergisi, C.31, S.2, 2015, s.167-200.

DOĞAN, Murat / BAYGIN, Cem: “Türk Borçlar Kanunu Tasarısı'nda Kira Sözleşmesine İlişkin Hükümler”, Hukuki Perspektifler Dergisi, S.4, Ağustos 2005, s.116-131.

DOĞAN, Murat: Konut ve Çatılı İşyeri Kira Sözleşmelerinin Sona Ermesi, Adalet, Ankara, 2011. [Sona Erme]

DOĞAN, Murat: “6098 Sayılı Türk Borçlar Kanununa Göre Konut ve Çatılı İşyeri Kiralarına İlişkin Hükümlerinin Değerlendirilmesi”, Prof.Dr. Cevdet YAVUZ’a Armağan, Marmara Üniversitesi Hukuk Fakültesi - Hukuk Araştırmaları Dergisi, Özel Hukuk Sempozyumu Özel Sayısı: 6098 Sayılı Türk Borçlar Kanunu Hükümlerinin Değerlendirilmesi Sempozyumu (3-4 Haziran 2011), Sempozyum No: III, 2011, s.501-523. [Sempozyum]

DURAL, Mustafa / SARI, Suat: Türk Özel Hukuku, C.1, Temel Kavramlar ve Medeni Kanunun Başlangıç Hükümleri, Filiz, İstanbul, 2018.

EREN, Fikret: Borçlar Hukuku Özel Hükümler, 4. Bası, Yetkin, Ankara, 2017.

ERZURUMLUOĞLU, Erzan: Sözleşmeler Hukuku (Özel Borç İlişkileri), 7.Baskı, Yetkin, Ankara 2017.

GÜMÜŞ, Mustafa Alper: “Yeni” 6098 Sayılı Türk Borçlar Kanunu’na Göre Kira Sözleşmesi (TBK m.299-356), Vedat Kitapçılık, 2. Bası, İstanbul 2012. (Kira Sözleşmesi)

GÜMÜŞ, Mustafa Alper: Borçlar Hukuku Özel Hükümler C.I, 3. Bası, Vedat Kitapçılık, İstanbul 2013. (Borçlar Özel) 
GÜMÜŞ, Mustafa Alper: "Kiracı ve Kiraya Veren Arasında Bir Gerilim Kaynağı Olarak Belirli Süreli Konut ve Çatılı İşyeri Kiralarında Kiraya Verenin Sahip Olduğu Kira Sözleşmesini Bildirim Yoluyla Sona Erdirme Hakkı (TBK m.347/I, c.3)”, Prof. Dr. Özer Seliçi'nin Anısına Armağan, Bahçeşehir Üniversitesi Hukuk Fakültesi Dergisi Özel Sayısı, C.11, S.145-146, Eylül-Ekim 2016, s.119-142. [Armağan].

HATEMİ, Hüseyin: Medeni Hukuk’a Giriş, 8.Bası, Oniki Levha, İstanbul 2017.

HEKİM, Aylin: Konut ve Çatılı İşyeri Kira Sözleşmelerinin Bildirim Yoluyla Sona Ermesi (TBK m. 347), Yayınlanmamış Yüksek Lisans Tezi, İstanbul Üniversitesi Sosyal Bilimler Enstitüsü Özel Hukuk Anabilim Dalı, İstanbul 2018.

IŞIKTAÇ, Yasemin / METIN, Sevtap: Hukuk Metodolojisi, Filiz, İstanbul 2010.

İNCEOĞLU, M. Murat: Kira Hukuku, C.2, 1.Bas1, XII Levha, İstanbul, 2014. [II].

KAPLAN, İbrahim: "Borçlar Kanunu Tasarısı Hakkındaki Görüşlerim”, Terazi Hukuk Dergisi, S.25, Eylül 2008, s.17-37.

KARABAĞ BULUT, Nil: Medeni Kanunun 23. Maddesi Kapsamında Kişilik Hakkının Sözleşme Özgürlüğüne Etkisi, 1. Bası, On İki Levha Yayınları, İstanbul, 2014.

KIRCA, Çiğdem: “Örtülü (Gizli) Boşluk ve Bu Boşluğun Doldurulması Yöntemi Olarak Amaca Uygun Sinırlama (Teleologische Reduktion)”, Ankara Üniversitesi Hukuk Fakültesi Dergisi, C.50, S.1, 2001, s.91-119.

KIRMIZI, Mustafa: Açıklamalı- İçtihatlı Kira Hukuku, 1.Baskı, Bilge, Ankara, 2013.

KOCAYUSUFPAŞAOĞLU, Necip/ HATEMİ, Hüseyin/ SEROZAN, Rona/ ARPACI, Abdulkadir: Borçlar Hukukuna Giriş, Hukuki İşlem, Sözleşme, 4. Bası'dan 7. Tıpkı Bası, İstanbul, Filiz, 2017.

KOÇ, Nevzat: "6098 Sayılı Türk Borçlar Kanununda Kira Sözleşmesine İlişkin Olarak Yapılan Yeni Düzenlemelerin Genel Değerlendirmesi” İstanbul Medipol Üniversitesi Hukuk Fakültesi Dergisi, İstanbul 2014, C.I, S.1, s.1-35; ayrıca bkz. Dokuz Eylül Üniversitesi Hukuk Fakültesi Dergisi, Prof. Dr. Şeref ERTAŞ’a Armağan, C. 19, Özel Sayı-2017, s. 69-107.

KÖSTEKÇİ, Yaşar: Borçlar Hukuku ve Anayasa'ya Aykırılık Boyutlarıyla 10 Yıl Uzama Süresi Sonu Kiracının Tahliyesi, Tahliyeden Korunma Önlemleri, Vedat, İstanbul, 2014.

KURDOĞLU, Bülent Nuri: “Türk Borçlar Kanunu Tasarısının İncelenmesi”, Ankara Barosu Dergisi, 2005/3, s.53-84.

KURŞAT, Pelin: Konut ve Çatılı İşyeri Kira Sözleşmesinin Bildirim Yoluyla Sona Erdirilmesi, Filiz, İstanbul, 2017.

NOMER, Haluk Nami / AKBULUT, Pakize Ezgi: Medeni Hukuka Giriş Dersleri, Bölüm I, 2.Bask1, Filiz, İstanbul 2018.

OĞUZMAN, M. Kemal / BARLAS, Nami: Medeni Hukuk, Giriş, Kaynaklar, Temel Kavramlar, 23.Bas1, Vedat, İstanbul, 2017.

OĞUZMAN, M. Kemal/ SELIÇİ, Özer/ OKTAY-ÖZDEMIR, Saibe: Kişiler Hukuku (Gerçek ve Tüzel Kişiler), 17.Bask1, Filiz, İstanbul, 2018.

ÖZ, Turgut; Yeni Borçlar Kanununun Getirdiği Başlıca Değişiklikler ve Yenilikler, 3. Bası, Vedat, İstanbul 2012.

ÖZDOĞAN, Mustafa/OYMAK, Tuba: 6098 sayılı Türk Borçlar Kanunu'nda Kira, Genel Hükümler, Konut ve Çatılı İşyeri Kirası, Tahliye, Bilge, Ankara 2013. 
ÖZTÜRK, Mehmet: "Konut ve Çatılı İşyeri Kira Sözleşmelerinin Sona Erme Halleri”, Dokuz Eylül Üniversitesi (D.E.Ü) Hukuk Fakültesi Dergisi, Prof. Dr. Şeref Ertaş’a Armağan, C.19, Özel Say1, 2017, s.1549-1595.

REMZİ, Mehmet/AYDIN, Sezer: Borçlar Hukuku Özel Hükümler, 8.Bası, İkinci Sayfa, 2017.

SANLI, Kerem Cem: "Kiraya Verenin On Yıllık Uzama Süresi Sonunda Bildirim ile Kira Sözleşmesini Sona Erdirmesi: Hukuk ve Ekonomi Perspektifinden Bir İnceleme”, Legal Hukuk Dergisi, S.151, 2015, s.103-148.

SEVER, Ömer: "Konut ve Çatılı İşyeri Kiralarında Sözleşmenin Sona Ermesi”, Hukuk ve Adalet Eleştirel Hukuk Dergisi, C.6, S.15, Legal, 2014, s.205-210.

SEROZAN, Rona: Medeni Hukuk, Genel Bölüm/Kişiler Hukuku, 8.Bask1, Vedat, İstanbul 2018.

ŞENYÜZ, Doğan: Borçlar Hukuku: Genel ve Özel Hükümler, 8.Bası, Ekin, Bursa, 2016.

TOPUZ, Seçkin/ CANBOLAT, Ferhat: “Taşınmazlara İlişkin Kira Sözleşmelerinin İçeriğinin Örtülü İrade Beyanıyla Değiştirilmesi” Hacettepe Hukuk Fakültesi Dergisi, C.I, S.1, Ankara 2011, s.1-31.

TÜRKMEN, Ahmet: “6098 Sayılı Türk Borçlar Kanunu'nun Kira Sözleşmesine İlişkin Yürürlüğü Ertelenen Hükümlerin Değerlendirilmesi”, Ankara Barosu Dergisi, 2015/1, s.341-368.

ÜNAL, Akın: Kelepçeleme Sözleşmeleri: Sözleşmelerdeki Hükümler Sebebiyle Kişinin Ekonomik Özgürlügünün Aşırı Derecede Sınırlanması, 2.Baskı, Adalet, Ankara, 2017.

YAVUZ, Cevdet/ACAR, Faruk/ ÖZEN, Burak: Cevdet Yavuz Türk Borçlar Hukuku Özel Hükümler, (Hazırlayanlar: Cevdet Yavuz/ Faruk Acar/ Burak Özen), 10. Bas1, Beta, İstanbul 2014.

YAVUZ, Nihat: 6098 Sayı1ı Türk Borçlar Kanunu'nun Getirdiği Değişiklikler ve Yenilikler (Genel Hükümler-Özel Hükümler), 3. Bas1, Adalet Yayınevi, Ankara 2012. [Değişiklikler]

YAVUZ, Nihat: Borçlar Hukuku El Kitabı, Adalet, Ankara, 2018. [Borçlar Hukuku]

YAVUZ, Nihat: Yeni TBK, HMK, İIK ve İstinafa Göre Kira Hukuku, Genişletilmiş 6.Baskı, Adalet, Ankara, 2018. [Kira Hukuku]

ZEVKLİLER, Aydın / GÖKYAYLA, K. Emre: Borçlar Hukuku Özel Borç İlişkileri, 18. Bası, Turhan, Ankara 2018.

\section{İnternet Kaynakları}

www.kazanci.com.tr [Kazancı İBB]

www.legalbank.com.tr [Legalbank]

www.lexpera.com.tr [Lexpera] 
